\title{
Functionalized Mesoporous SBA-15 silica: Recent trends and Catalytic applications
}

Received 00th January 20xx, Accepted 00th January 20xx

DOI: $10.1039 / x 0 x \times 00000 x$

\begin{abstract}
Priyanka Verma, $^{\text {a,b }}$ Yasutaka Kuwahara, ${ }^{a, c, d}$ Kohsuke Mori,, ${ }^{a, c}$ Robert Raja ${ }^{b}$ and Hiromi Yamashita*a,c
The development of advanced materials for heterogeneous catalytic applications requires fine control over the synthesis and structural parameters of the active site. Mesoporous silica materials have attracted increasing attention to be considered as an important class of nanostructured support materials in heterogeneous catalysis. The large surface area, well-defined porous architecture and their ability to incorporate metal atoms within the mesopores serve as a promising support material for designing a variety of different catalysts. Especially, SBA-15 mesoporous silica has its broad applicability in catalysis because of its comparatively thicker walls leading to higher thermal and mechanical stability. In this review article, various strategies to functionalize SBA-15 mesoporous silica has been reviewed with a view to evaluating their efficacy in different catalytic transformation reactions. Special attention has been given to the molecular engineering of the silica surface, within the framework and within the hexagonal mesoporous channels for anchoring metal oxides, single-site species and metal nanoparticles (NPs) serving as catalytically active sites.
\end{abstract}

\section{Introduction}

As per IUPAC nomenclature, mesoporous materials can be defined as nanostructures with pore diameters ranging from 2$50 \mathrm{~nm} .^{1,2}$ They are preferred materials because of their ordered framework, high surface area, large pore size and pore volumes which create easy diffusion of substrate molecules..$^{3-5}$ Till now, they have been applied widely into various fields including catalysis ${ }^{6-10}$, drug delivery ${ }^{11-14}$, membrane separation ${ }^{15}$, biosensing ${ }^{16-18}$ and sorption analysis. ${ }^{19-21}$ The most commonly employed mesoporous materials for various applications are alumina, silica, carbon and transition metal oxides. Silica forms the major component of these materials for its chemicalinertness, abundance, stability and low cost. The immobilization of active species on such support materials assists in the easy recyclability and even higher catalytic performances in comparison to homogeneous analogues. ${ }^{22,23}$

Mesoporous silica materials have attracted increasing attention to be considered as an important class of nanostructured support materials. ${ }^{24-26}$ The large surface area, well-defined porous architecture and their ability to incorporate metal atoms within the mesopores serve as a promising support material for designing a variety of different catalysts. ${ }^{27-30}$ The downsizing of catalysts into nanoscale regime to form fine particles leads to intrinsic properties owing to quantum size effects. Such fine NPs exhibit extremely high catalytic activity

\footnotetext{
a. Division of Materials and Manufacturing Science, Graduate School of Engineering, Osaka University, 2-1 Yamadaoka, Suita, Osaka 565-0871, Japan.

b. School of Chemistry, University of Southampton, University Road, Highfield,

Southampton, SO17 1 BJ, United Kingdom.

c. Units of Elements Strategy Initiative for Catalysts and Batteries, Kyoto University, Katsura, Kyoto 615-8520, Japan.

d.JST, PRESTO, 4-1-8 Honcho, Kawaguchi, Saitama 332-0012, Japan.
}

due to decrease in the particle size and high surface area. Isolated single-atom catalysis is very popular because of high ratio of low coordinated atoms. However, it is still a challenge to isolate such species due to the increase in their surface energy values. Hence, suitable support materials are needed that can confine and site-isolate such NPs and interact strongly in order to maintain their intrinsic properties. Predominantly, mesoporous materials can be utilized as the host to design such catalytic systems, as confinement in a mesostructured environment can render the following advantages: (i) pore structure tunability, (ii) pore connectivity allowing superior mass-transport diffusion for greater product yield, (iii) complete transparency in the UV-region highlighting its optical inertness and (iv) thermal and mechanical stability. The incorporation of metal species in the mesoporous framework develops ultrafine particles in a controlled fashion which display outstanding catalytic performances. Advanced functional materials can be developed by carefully utilizing the confined pore spaces and controlled structure of mesoporous materials (for example; mesoporous silica) to integrate active species within the mesoporous channels or in the framework of silica matrix.

The first discovery of mesoporous materials was reported by Mobil Corporation in 1992 and since then much attention has been paid to develop their synthesis and application. ${ }^{31}$ In 1998, the SBA-15 mesoporous silica was at first reported by Zhao and coworkers at University of California, Santa Barbara and hence the material was named Santa Barbara Amorphous type 15 material. ${ }^{32}$ Eventually, it became one of the popular support materials to design and develop heterogeneous catalysts modified by metal NPs and different types of metal oxides. The 2D hexagonal array of uniformly distributed mesopores plays a significant role in the easy diffusion of substrate molecules in comparison to the conventional solid supports and other 
mesoporous silica materials. ${ }^{33-36}$ It has broad applicability in designing materials and in applied catalysis because of the comparatively thicker walls leading to higher thermal and mechanical stability. ${ }^{37-40}$ The large surface area affords easy dispersion of metal nanoparticles (NPs) with narrow size distribution. Table 1 summarizes the physicochemical characteristics of SBA-15 in comparison with other popular mesoporous silica support materials such as SBA-16, MCM-41, MCM-48 and HMS. The superior characteristics of SBA-15 as a support material is because of its larger pore diameter and thicker walls. Joseph et al. studied the comparative catalysis of $\mathrm{Ru}$ complex ([RuHCl(CO)( $\left.\left.\mathrm{PPh}_{3}\right)_{3}\right]$ ) immobilized on SBA-15 and MCM-41 for hydrogenation of olefin (styrene). ${ }^{56}$ The neat Ru complex, Ru complex immobilized on MCM-41 and SBA-15 displayed TOF values of $16.7,80.0$ and 122.8 at $333 \mathrm{~K}$ for $12 \mathrm{~h}$. The higher catalytic activity (TOF values) of SBA-15, when compared with MCM-41 was attributed to the facile access of substrate molecules to the active sites of complex in the mesoporous channels.

Support materials have been classified into active and inert species based on their ability to participate in catalytic reactions. The inert support materials mainly serve the function of dispersing the metal oxide or metal NPs whereas the active materials provide the support and the active site to facilitate the catalytic reaction. SBA-15 has extensively been used as the inert support material in a variety of catalytic transformation reactions..$^{41-45}$ However, the material can be made active by functionalizing the surface or incorporating species like metal NPs or oxides. ${ }^{46}$ Surface functionalization can be done by coating the silica surface with desired functionalities

Table 1. Comparison of properties of SBA-15 with other mesoporous support materials and its structural advantages.

\begin{tabular}{|c|c|c|c|c|c|}
\hline \multirow{2}{*}{ Properties } & \multicolumn{5}{|c|}{ Different types mesoporous silica support materials } \\
\hline & SBA-15 & SBA-16 & MCM-41 & MCM-48 & HMS \\
\hline Full-name & $\begin{array}{l}\text { Santa Barbara } \\
\text { Amorphous Type } \\
15\end{array}$ & $\begin{array}{l}\text { Santa Barbara } \\
\text { Amorphous Type } \\
16\end{array}$ & $\begin{array}{l}\text { Mobil } \\
\text { Composition of } \\
\text { Matter No. } 41 \\
\end{array}$ & $\begin{array}{l}\text { Mobil Composition } \\
\text { of Matter No. } 48\end{array}$ & $\begin{array}{l}\text { Hexagonal } \\
\text { Mesoporous } \\
\text { Silica }\end{array}$ \\
\hline $\begin{array}{c}\text { Structure } \\
\text { directing } \\
\text { agent }\end{array}$ & $\begin{array}{l}\text { Pluronic } 123 \text { (non- } \\
\text { ionic) }\end{array}$ & $\begin{array}{l}\text { Pluronic F127 } \\
\text { (non-ionic) }\end{array}$ & CTAB (cationic) & CTAB (cationic) & $\begin{array}{l}\text { Amines (non- } \\
\text { ionic) }\end{array}$ \\
\hline $\begin{array}{l}\text { Synthesis } \\
\text { medium }\end{array}$ & Acidic $\left(\mathrm{pH}^{\sim} 1\right)$ & Acidic $\left(\mathrm{pH}^{\sim} 1\right)$ & $\begin{array}{l}\text { Basic (pH 11- } \\
13)\end{array}$ & Basic $\left(\mathrm{pH}^{\sim} 11-13\right)$ & Basic $\left(\mathrm{pH}^{\sim 9}\right)$ \\
\hline $\begin{array}{l}\text { Structural } \\
\text { details }\end{array}$ & $\begin{array}{l}\text { Hexagonal pores, } \\
2 \mathrm{D} \text { array, } p 6 \mathrm{~mm} \\
\text { symmetry, } \\
\text { channels } \\
\text { interconnected by } \\
\text { small micropores }\end{array}$ & $\begin{array}{l}\text { 3D cubic } \\
\text { arrangement } \\
\text { connected by } \\
\text { spherical cavities, } \\
\text { Im3m space } \\
\text { symmetry }\end{array}$ & $\begin{array}{l}\text { 1D mesopores, } \\
\text { p6mm } \\
\text { hexagonal, } \\
\text { absence of } \\
\text { interconnected } \\
\text { pores }\end{array}$ & $\begin{array}{l}l a 3 d, 3 D \text { cubic } \\
\text { continuous pore } \\
\text { arrangement }\end{array}$ & $\begin{array}{l}\text { Sponge-like } \\
\text { particles, } \\
\text { worm-hole } \\
\text { mesostructur } \\
\text { ed } \\
\text { framework }\end{array}$ \\
\hline $\begin{array}{c}\text { Pore } \\
\text { diameter }\end{array}$ & $\begin{array}{l}\text { Uniform and } \\
\text { larger pore } \\
\text { diameter (4-30 } \\
\mathrm{nm} \text { ) facilitating } \\
\text { easy diffusion }\end{array}$ & $\begin{array}{l}\text { Similar pore } \\
\text { diameter values } \\
\text { but non-uniform } \\
\text { mesopores }\end{array}$ & $\begin{array}{l}\text { Smaller pore } \\
\text { diameter } 1.5-10 \\
\mathrm{~nm} \text { hindering } \\
\text { the diffusion of } \\
\text { substrates }\end{array}$ & $\begin{array}{l}\text { Smaller pore } \\
\text { diameter }(2-3 \mathrm{~nm}) \\
\text { hindering diffusion } \\
\text { of substrates }\end{array}$ & $\begin{array}{l}\text { Smaller pore } \\
\text { diameter } \\
\text { than SBA-15 } \\
(2-10 \mathrm{~nm})\end{array}$ \\
\hline Surface area & $\begin{array}{l}\text { Higher surface } \\
\left.\text { area ( } 1000 \mathrm{~m}^{2} / \mathrm{g}\right) \text {, } \\
\text { high surface area } \\
\text { to volume ratio }\end{array}$ & $\begin{array}{l}\text { Comparable } \\
\text { surface area } \\
\text { values to SBA-15 }\end{array}$ & $\begin{array}{l}\text { Lower surface } \\
\text { area }\left(\sim 800 \mathrm{~m}^{2} / \mathrm{g}\right)\end{array}$ & $\begin{array}{l}\text { Higher surface area } \\
\left(\sim 1100 \mathrm{~m}^{2} / \mathrm{g}\right)\end{array}$ & $\begin{array}{l}\text { Surface area } \\
(800- \\
\left.1000 \mathrm{~m}^{2} / \mathrm{g}\right)\end{array}$ \\
\hline Stability & $\begin{array}{l}\text { Thick walls (up to } \\
9 \mathrm{~nm} \text { ) and hence } \\
\text { more thermally } \\
\text { stable }\end{array}$ & $\begin{array}{l}\text { Thick walls } \\
\text { comparable to } \\
\text { SBA-15 }\end{array}$ & $\begin{array}{l}\text { Thin walls ( } 0.5 \\
\mathrm{~nm} \text { ) and hence } \\
\text { poor } \\
\text { hydrothermal } \\
\text { stability }\end{array}$ & $\begin{array}{l}\text { Thin walls and } \\
\text { hence } \\
\text { comparatively less } \\
\text { thermally stable }\end{array}$ & $\begin{array}{l}\text { Less ordered } \\
\text { structure but } \\
\text { comparable } \\
\text { stability }\end{array}$ \\
\hline
\end{tabular}




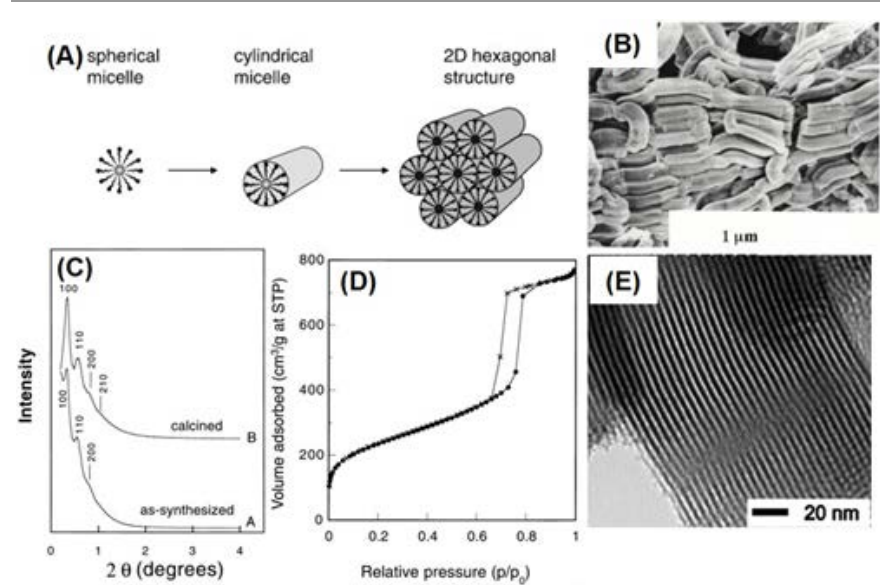

Fig. 1. (A) Illustration of initial stages of SBA-15 synthesis. Reproduced with permission from ref. [49] Copyright 2008 Elsevier. (B) Scanning electron micrograph of as synthesized SBA-15, (C) XRD patterns of as-synthesized SBA-15 and calcined SBA-15, (D) Nitrogen adsorption-desorption isotherm and (E) TEM image of the calcined SBA-15. Reproduced with permission from ref. [86] Copyright 1998 The American Association for the Advancement of Science.

such as amine, sulphonyl, thiol and carboxyl groups. The incorporation of heteroatoms within the framework of SBA-15 can be a difficult task because of the strongly acidic conditions used in the synthesis process. In such strong conditions $(\mathrm{pH}<1)$, metal species exist as cations rather than oxo species and hence it is difficult to incorporate active sites into the framework. Some research reports outline the incorporation of heteroatoms, avoiding the use of strong acidic conditions in the synthesis procedure. ${ }^{47,48}$ The strategies to functionalize and modify the silica surface has been discussed briefly in this review paper. The scope of review papers focused on SBA-15 discussing the overview of synthesis ${ }^{49-53,66}$, applications in C-C coupling reactions ${ }^{54,55}$, oxidation ${ }^{57,65,67}$, olefin metathesis ${ }^{69}$, adsorption $^{58}$, drug delivery ${ }^{59}$ and others ${ }^{60-64,68}$ are summarized in Table 2.

As of today, one of the most researched applications in materials is heterogeneous catalysis. ${ }^{70-75}$ An important objective is to design composite materials containing active and selective catalytic centres. The heterogeneous catalysts developed on mesoporous silica as a support material display enhanced catalytic performances which can be attributed to the generation of new geometries and arrangements, enhanced stability of active site and refinement of the electronic states. ${ }^{76-}$ 78 The pore confinement and local environment leads to the easy diffusion of substrate molecules. ${ }^{79-81}$ The theme of this review paper is to summarize the recent trends in heterogeneous catalysis for the variety of chemical transformation reactions.

Following our previous publications in catalysis on heteroatom modified mesoporous silica, ${ }^{82-85}$ here in this review, we intend to highlight the recent catalytic applications demonstrated by other research groups. The design and functionalization of heterogeneous catalysts using SBA-15 silica as the promising host material has been summarized. The functionalization can be categorized into i) surface modification ii) heteroatom incorporation for example; single-site $\mathrm{Ti}, \mathrm{Zr}$, Mo etc. doped within the framework, iii) immobilization of metal NPs and immobilization of metal oxides within the pore channels. The recent advances for their applications in epoxidation, selective hydrogenation, hydrogen generation, ethanol oxidation, dye degradation, soot combustion, water splitting, and esterification are summarized. Finally, we end with discussing some miscellaneous species supported mesoporous silica, SBA-15 like MOFs and zeolites for different catalytic reactions.

\section{Synthesis and functionalization of mesoporous silica SBA-15}

\subsection{Synthesis and tailoring of the morphology of SBA-15}

The synthesis of SBA-15 involves the use of a template dissolved in acidic solution followed by the dropwise-addition of silica source. Typically, an amphiphilic triblock copolymer consisting of ethylene and propylene oxide units $\left(\mathrm{EO}_{20} \mathrm{PO}_{70} \mathrm{EO}_{20}\right.$, Pluronic $\mathrm{P} 123)$ is used as the structure-directing agent which is dissolved in water and $\mathrm{HCl}$ under vigorous stirring at moderate temperature. The synthesis requires strong acidic conditions $\mathrm{pH}$ $\sim 1$ for the precipitation of silica gel. The silica source, tetraethyl orthosilicate (TEOS) is then dropwise added and stirred. Following this, the suspension is aged in the Teflon bottle at an increased temperature overnight and the white solid is recovered by filtration, washing and drying overnight. The SBA15 was obtained after calcination in air to remove the surfactant template as illustrated in Fig. $\mathbf{1}$ (A). ${ }^{86}$

The ratio of ethylene and propylene units (EO: PO) in the triblock copolymer also plays an important role in deciding the geometrical arrangement of ordered silica. The lower ratio forms a $56 \mathrm{~mm}$ hexagonal morphology whereas the higher ratio leads to the formation of cubic morphology. At $\mathrm{pH}$ values ranging from 2 to 6 , no precipitation of silica takes place because of the lower isoelectric point of silica equal to $\mathrm{pH} 2$. At $\mathrm{pH}<1$, acidic environment forms the protonated silicate ions which attract the hydrophilic PEO species leading to the formation of a self-assembled silica-polymer phase. The structure of SBA-15 also found to contain micropores that interconnect the ordered mesopores within the framework. The micropores are generated perpendicular to the hexagonal channels by passing through the silica walls.

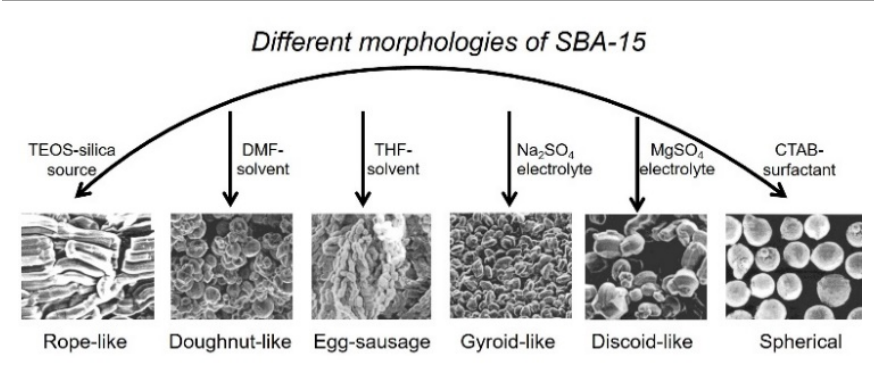

Scheme 1. Different morphologies of SBA-15 by the addition of co-solvent, electrolytes, CTAB surfactant and silica source. 
Table 2. Synoptic table of recently published review papers using SBA-15 mesoporous silica material

\begin{tabular}{|c|c|c|}
\hline Title & Scope & Ref. \\
\hline Initial stages of SBA-15 synthesis: An overview & $\begin{array}{l}\text { Studying the stages in the synthesis of SBA-15 using } \\
\text { in situ time-resolved neutron scattering experiments }\end{array}$ & 49 \\
\hline $\begin{array}{l}\text { Hydrothermally stable and catalytically active } \\
\text { ordered mesoporous materials assembled from } \\
\text { preformed zeolite nanoclusters }\end{array}$ & $\begin{array}{l}\text { Assembly of preformed zeolite precursors with } \\
\text { surfactants to synthesize a series of ordered } \\
\text { mesoporous materials }\end{array}$ & 50 \\
\hline $\begin{array}{l}\text { Surface molecular engineering in the confined } \\
\text { space of templated porous silica }\end{array}$ & $\begin{array}{l}\text { Approaches to develop templated mesoporous silica } \\
\text { materials for their applications in catalysis, } \\
\text { adsorption, sensing and drug delivery. }\end{array}$ & 51 \\
\hline $\begin{array}{l}\text { A review: Mesoporous Santa Barbara } \\
\text { Amorphous-15, Types, synthesis and its } \\
\text { applications towards biorefinery Production }\end{array}$ & $\begin{array}{l}\text { Various types and different synthesis of modifying } \\
\text { SBA-15 are discussed for its application in } \\
\text { biorefinery production. }\end{array}$ & 52 \\
\hline $\begin{array}{l}\text { An overview of ordered mesoporous material } \\
\text { SBA-15: synthesis, functionalization and } \\
\text { application in oxidation reactions }\end{array}$ & $\begin{array}{l}\text { Synthesis and application of SBA-15 in oxidation } \\
\text { reactions. }\end{array}$ & 53 \\
\hline $\begin{array}{l}\text { Applications of SBA-15 supported } \mathrm{Pd} \text { metal } \\
\text { catalysts as nanoreactors in } \mathrm{C}-\mathrm{C} \text { coupling } \\
\text { reactions }\end{array}$ & $\begin{array}{l}\text { Suzuki-Miyaura, Mizoroki-Heck and Sonogashira } \\
\text { Coupling reaction with Pd anchored on SBA-15 } \\
\text { catalysts }\end{array}$ & 54 \\
\hline $\begin{array}{l}\text { Recent advances in the application of } \\
\text { heterogeneous nanocatalysts for Sonogashira } \\
\text { coupling reactions }\end{array}$ & $\begin{array}{l}\text { Efforts, limitations and green aspects for preparing } \\
\text { Pd based heterogeneous catalysts for carbon- } \\
\text { carbon bond formation reaction }\end{array}$ & 55 \\
\hline $\begin{array}{l}\text { Some novel porous materials for selective } \\
\text { catalytic oxidations }\end{array}$ & $\begin{array}{l}\text { Surface engineering and design of heteroatom } \\
\text { incorporated mesoporous silica as single-site } \\
\text { photocatalysts for oxidation reactions }\end{array}$ & 57 \\
\hline $\begin{array}{l}\text { Adsorption separation of methyl chloride from } \\
\text { nitrogen using ZSM- } 5 \text { and mesoporous SBA-15 }\end{array}$ & $\begin{array}{l}\text { Adsorption capacities of ZSM- } 5 \text { and SBA- } 15 \text { towards } \\
\text { methyl chloride and nitrogen for the separation of } \\
\text { gases }\end{array}$ & 58 \\
\hline The role of SBA-15 in drug delivery & $\begin{array}{l}\text { Application of pure and modified SBA-15 as drug } \\
\text { delivery agents }\end{array}$ & 59 \\
\hline $\begin{array}{l}\text { Synthesis of gold catalysts supported on } \\
\text { mesoporous silica materials: Recent } \\
\text { developments }\end{array}$ & $\begin{array}{l}\text { Active gold catalysts supported on mesoporous silica } \\
\text { along with detailed examples of preparative } \\
\text { methods and selected applications. }\end{array}$ & 60 \\
\hline $\begin{array}{l}\text { Pt nanoparticles supported on SBA-15: Synthesis, } \\
\text { characterization and applications in } \\
\text { heterogeneous catalysis }\end{array}$ & $\begin{array}{l}\text { Synthesis of Pt/SBA-15 by different methods its and } \\
\text { application in catalytic reactions like CO oxidation, } \\
\text { alcohol oxidation, toluene hydrogenation etc. }\end{array}$ & 61 \\
\hline Block copolymer-templated mesoporous oxides & $\begin{array}{l}\text { Synthesis of mesoporous materials using template } \\
\text { copolymer and understanding their physical, } \\
\text { chemical and processing parameters. }\end{array}$ & 62 \\
\hline $\begin{array}{l}\text { Developing advanced catalysts for the } \\
\text { conversion of polyolefinic waste plastics into } \\
\text { fuels and chemicals }\end{array}$ & $\begin{array}{l}\text { Catalytic cracking of polyolefins especially focused } \\
\text { on the role of catalysts toward the synthesis of fuels } \\
\text { and chemicals }\end{array}$ & 63 \\
\hline $\begin{array}{l}\text { Metal nanoparticles syntheses on lonic Liquids } \\
\text { functionalized mesoporous silica SBA-15 }\end{array}$ & $\begin{array}{l}\text { Preparative methods of highly dispersed metal NPs } \\
\text { within the pores of SBA-15 using ionic liquid } \\
\text { stabilizers }\end{array}$ & 64 \\
\hline $\begin{array}{l}\text { SBA-15 as a support for effective olefin } \\
\text { metathesis catalysts }\end{array}$ & $\begin{array}{l}\text { Catalytic transformation of olefinic substrates for a } \\
\text { wide range of applications in organic synthesis }\end{array}$ & 69 \\
\hline $\begin{array}{l}\text { SBA-15 anchored metal containing catalysts in } \\
\text { the oxidative desulfurization process }\end{array}$ & $\begin{array}{l}\text { Active metal species supported SBA-15 for oxidative } \\
\text { desulfurization of model or real fuels }\end{array}$ & 70 \\
\hline $\begin{array}{l}\text { Synthesis and properties of SBA-15 modified } \\
\text { with non-noble metals }\end{array}$ & $\begin{array}{l}\text { Synthesis and physico-chemical properties of non- } \\
\text { noble metal (metallic or oxides) modified SBA-15 }\end{array}$ & 71 \\
\hline
\end{tabular}




\begin{tabular}{|l|l|c|}
\hline $\begin{array}{l}\text { Mesoporous silica-based gold catalysts: Novel } \\
\text { synthesis and application in catalytic oxidation of } \\
\text { CO and volatile organic compounds (VOCs) }\end{array}$ & $\begin{array}{l}\text { Synthesis and catalytic application of gold catalysts } \\
\text { supported on SBA-15 for the oxidation of methanol } \\
\text { and dimethyldisulfide }\end{array}$ & 72 \\
\hline $\begin{array}{l}\text { Advances in click chemistry for silica-based } \\
\text { material construction }\end{array}$ & $\begin{array}{l}\text { Triazole modified silica materials investigated for } \\
1,3-\text { dipolar cycloaddition reaction }\end{array}$ & 73 \\
\hline $\begin{array}{l}\text { Design of silver-based controlled nanostructures } \\
\text { for plasmonic catalysis under visible light } \\
\text { irradiation }\end{array}$ & $\begin{array}{l}\text { Morphology-controlled plasmonic silver NPs within } \\
\text { SBA-15 for their preparative techniques and } \\
\text { efficient catalysis under visible light irradiation }\end{array}$ & $\begin{array}{c}160, \\
164\end{array}$ \\
\hline
\end{tabular}

Such support systems with dual-porosity are advantageous for carrying out adsorption and a variety of catalytic reactions. The microporosity in SBA-15 can be tuned by changing the ratio of P123 polymer and silica source in the starting gel suspension. ${ }^{87,88}$

Researchers have studied the effect of synthesis conditions like temperature, copolymer type, silica source and addition of swelling agent to generate different textural properties like surface area, pore size and pore volume by retaining the ordered framework unchanged. ${ }^{89}$ The average pore size can vary from 4 to $10 \mathrm{~nm}$ by altering the synthesis conditions, but it can be increased to $30 \mathrm{~nm}$ upon addition of the swelling agent. A significant amount of effort has been carried out to tailor the porous structure and physico-chemical properties of the ordered framework of SBA-15. The different morphology of SBA-15 like rod, sphere and hexagonal has been explored by carefully tuning the synthesis conditions like temperature or use of co-solvent and co-surfactants. ${ }^{90}$ Other parameters like rate of hydrolysis, condensation of silica and interaction of silica polymer with the template can significantly affect the morphology and particle size of silica.

Small-angle XRD confirms the hexagonally-ordered porous structure by displaying three well-defined peaks attributing to the (100), (110) and (200) planes of SBA-15 (Fig. 1 (C)). The peak intensities of as-synthesized SBA-15 enhances after calcination and can easily be varied by changing the synthesis temperature. The peak intensities have been correlated with the thickness of pore walls. The decreased relative intensity of (200) peak to the (110) peak attributes to the decrease in the thickness of the pore wall. The thermogravimetric analysis (TGA) of assynthesized SBA-15 material displays up to $50 \%$ weight loss in the temperature range from 373 to $923 \mathrm{~K}$, which can be accounted for the loss of water and polymer template from the silica framework. The loss of polymer template varied on changing the washing solvent from water to ethanol and retained in the framework up to $900 \mathrm{~K}$. The water-washed SBA15 had a higher content of template retained than ethanolwashed samples.

The $\mathrm{N}_{2}$ physisorption analysis displayed a Type IV hysteresis curve with sharp adsorption and desorption curves, indicating the mesoporous framework of the silica material as displayed in Fig. 1 (D). The sharpness of the curve defines the narrow pore size distribution in the framework within the pressure range from 0.5 to 0.8 . This position of relative pressure can be tuned by controlling the temperature of synthesis. Moreover, the pore size can also be tailored and tuned by carefully monitoring the synthesis temperature, solvent and aging temperature. The average pore diameter was found to be in the range of 5-10 nm. The surface area and pore volume of as-synthesized SBA-15 are found to be in the range of $500-900 \mathrm{~m}^{2} \mathrm{~g}^{-1}$ and $0.4-1.0 \mathrm{~cm}^{3} \mathrm{~g}^{-1}$, respectively. As mentioned earlier, the presence of micropores was also observed with a pore diameter of about $2 \mathrm{~nm}$ which was further confirmed by $\alpha_{\mathrm{s}}$-plot analysis. The micropore volume varied from 0.06 to $0.12 \mathrm{~cm}^{3} \mathrm{~g}^{-1}$. The morphology of SBA15 synthesized by using TEOS as the silica source appears to be rope-like as seen by scanning electron microscopy SEM image (Fig. 1 (B)). Transmission electron spectroscopy (TEM) further confirmed the parallel orientation of the ordered channels present along the axis as shown in Fig. 1 (E).

The morphology of SBA-15 can be tuned and controlled by varying the parameters involved during synthesis, such as the use of block copolymer, co-solvent, surfactant, addition of swelling agents or electrolytes as shown in Scheme 1. ${ }^{91-95}$ The different morphologies, apart from the characteristic rope-like structure, which has been prepared and studied by different groups are rod, sphere, fiber, doughnut, prism, discoid like mesoporous silica. A fiber-like structure can be obtained by using tetramethyl orthosilicate (TMOS) as the silica source instead of TEOS and following the exact same procedure as for typical SBA-15. It forms in high yield of $95 \%$ and consists of a bundle of wires joined together with an overall diameter of about $300 \mathrm{~nm}$. XRD pattern displayed the characteristic peaks of well-ordered 2D nanostructure, indicating the successful formation of mesoporous silica in different morphology. After calcination, TEM images also confirmed the orientation of uniform channels present in SBA-15. The surface area and pore volume of fiber-like SBA-15 was reported to be $710 \mathrm{~m}^{2} \mathrm{~g}^{-1}$ and $1.3 \mathrm{~cm}^{3} \mathrm{~g}^{-1}$, respectively. ${ }^{90}$

The rope-like morphology with a diameter of $1 \mu \mathrm{m}$ formed by using TEOS as the silica source, which aggregates together to form a wheat-like nanostructure. On adding $N, N$ dimethylformamide (DMF) as the co-solvent during the synthesis, doughnut-like silica, can be obtained with an overall diameter of $1 \mu \mathrm{m}$. Circle-type channels with ordered hexagonal mesostructure were revealed by the TEM images. Ethanol and tetrahydrofuran (THF) as co-solvents led to the sausage-like or rope-like SBA-15 particle formation. The curvature energy at the interface of silica and triblock polymer plays an important role in deciding the resultant morphology of the mesoporous silica. The high polarity of the solvents introduces more curvature for the reaction mixture. Co-solvents such as 1,3,5trimethylbenzene and hexane act as the swelling agent to form 
large-sized pores. ${ }^{95}$ Further, the morphology also shows great dependence on the addition of electrolytes during the synthesis like $\mathrm{Na}_{2} \mathrm{SO}_{4}$ and $\mathrm{MgSO}_{4}$ forming gyroid and discoid-like structures, respectively. Low charge electrolyte addition like LiCl and $\mathrm{NaCl}$ forms continuous 3D meso-macroporous structured silica. An example of adding co-surfactant like cetyltrimethylammonium bromide (CTAB) leads to the formation of hard spheres in micrometre range, giving higher yields of $90 \%$.

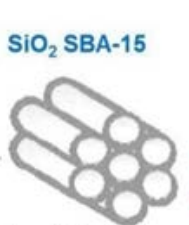

$S_{B E T}=592 \mathrm{~m}^{2} \mathrm{~g}^{-1}$ $S_{B \in C}=592 \mathrm{~m}^{2} \mathrm{~g}^{-1}$
Pore size $=6.5 \mathrm{~nm}$

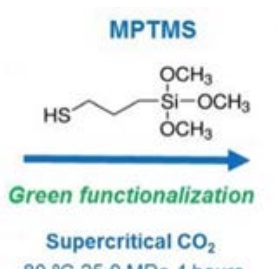

$80^{\circ} \mathrm{C} 25.0 \mathrm{MPa} 4$ hours

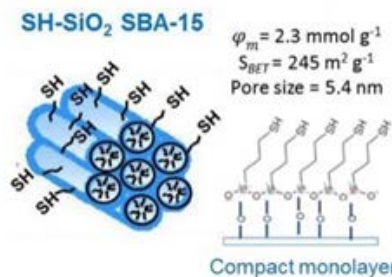

Compact monolayer supercritical $\mathrm{CO}_{2}$. Reproduced with permission from ref. [111] Copyright 2017 Elsevier.

The surfactant addition lowers the curvature energy to form morphologies like sphere, gyroid and discoid. The spheres of diameter $\sim 1 \mu \mathrm{m}$ were uniformly distributed and found to increase their size on increasing the concentration of the surfactant.

\subsection{Surface functionalization by different functional groups}

The uniformly distributed hexagonal channels with narrow pore size distribution along with characteristics like high surface area and thermal stability make SBA-15 a promising candidate to be employed as a support material. However, the bare SBA-15 has an absence of functionality and is inactive to carry out chemical transformation reactions. To enhance the versatility of its application, the surface of silica is often functionalized with various active site entities. It can serve as the nanoreactors by integrating metal NPs, metal complex species with the silanol groups present within the cavities or in the mesoporous channels. ${ }^{96-98}$

The overall neutral framework of SBA-15 silica allows the straightforward modification by organic functional groups. It can be done by two simple methods: direct or one-pot synthesis and post-synthesis modification. The direct method involves the co-condensation of the dopant compound which is added during the synthesis of SBA-15, resulting in the compound doped in the matrix of mesoporous silica. The post-modification method also known as grafting method involves compounds like organosilanes, silazanes, chlorosilanes to react with the free surface silanol groups after the synthesis of SBA-15. The direct method of synthesis is simpler and more advantageous because it develops the active site and forms the mesoporous material in a single step. Further, it is uniformly distributed within the framework, but doping with higher concentration may lead to slower condensation rates and even the formation of disordered material. The post-modification method can easily form high-quality support material and ensure site-isolation by immobilizing the desired functional groups on its surface after synthesizing SBA-15. This section has been broadly discussed in this review paper, further exploring the catalytic applications of such modified catalyst materials. Grafting can introduce a variety of functional groups like amines, sulphonyl, carboxyl, thiol and nitriles. The functionalized SBA-15 can be broadly categorized into different types based on the functional group used; modification of SBA-15 with acidic functional groups (sulphonic, carboxyl)99-102, basic functional groups (aminopropyl, triazole), amphoteric groups (imidazole), ${ }^{103,104}$ and miscellaneous species like enzyme, MOF, zeolite, fullerene etc. ${ }^{105-107}$ The synthesis of bifunctional silica with the presence of acid and basic sites has also been briefly discussed.

Wolosiuk's group has employed click-chemistry to react thiocarboxylic acid with vinyltrimethoxysilane, photochemically, to form free carboxylic acid-functionalized silica. ${ }^{108}$ The silica characterized by SEM and $\mathrm{N}_{2}$ physisorption confirmed the preservation of mesostructured SBA-15. The successful incorporation of $-\mathrm{COOH}$ group was confirmed by measuring FT-IR spectra and more negative zeta potential values. This one-step synthetic route can be extended to functionalize other types of mesoporous silica materials. The applicability of the material was tested in the $\mathrm{Cu}$ adsorption experiment because $\mathrm{Cu}^{2+}$ is treated as a pollutant emerging from electroplating and mining industries. It was interesting to observe that SBA-15 did not show any affinity towards $\mathrm{Cu}^{2+}$ ions whereas carboxylic acid-modified SBA-15 achieved adsorption equilibrium within $30 \mathrm{~min}$. Another interesting report describes the selective functionalization of the inner and outer surface of SBA-15. ${ }^{109}$ This selective functionalization can be applied to applications such as drug delivery where external surface helps in the recognition of body-tissue and inner surface helps in the release of drug molecules. Further, it facilitated the controlled synthesis of NPs employed in catalysis. A pore-protection strategy was used to selectively fill the pores with P123 surfactant of as-synthesized SBA-15. Following this, the surface can be functionalized by a silylating agent and consecutively the surfactant can be removed by extraction with ethanol. The accessible mesopores can then be further functionalized. The characterization techniques like solid-state NMR and $\mathrm{N}_{2}$ physisorption analysis confirmed the structural details of silica.

Another unique approach towards the functionalization of silica is using supercritical $\mathrm{CO}_{2}\left(\mathrm{scCO}_{2}\right)$ as the green and sustainable route in comparison to toxic organic solvents. ${ }^{110}$ For amine group functionalization, (3-aminopropyl)triethoxysilane (3-APTS) was used with $\mathrm{scCO}_{2}$ with $10 \mathrm{~mol} \%$ ethanol at moderate temperature and pressure $(12.0 \mathrm{MPa}, 313 \mathrm{~K})$. A maximum of $2.7 \mathrm{mmolg}^{-1}$ of 3-APTS amine could be introduced in the silica using $\mathrm{ScCO}_{2}$. The surface area, pore volume and pore size decreased consecutively on increasing the grafting density indicating the successful coating of silica. The aminefunctionalized silica displayed $1.5 \mathrm{mmol} \mathrm{g}^{-1}$ capacity of $\mathrm{CO}_{2}$ adsorption at ambient pressure conditions. In another report published by the same research group, thiol groups were introduced on silica employing the same strategy using mercaptopropyltrimethoxy silane (MPTMS) mixed in $\mathrm{ScCO}_{2}$ as illustrated in Fig. 2. The successful grafting was verified by FT- 
IR, TGA and elemental analysis. A grafting density of $2.3 \mathrm{mmol}$ $\mathrm{g}^{-1}$ was obtained at lower temperatures and shorter times in comparison to conventional functionalization technique. ${ }^{111}$

Lv et al. reported the modification of SBA-15 with tungsten and organic groups originating from diphenyldichlorosilane (DPHS). ${ }^{112}$ This organic mesoporous silica was tested in the oxidation of cyclopentene to glutaric acid by using $\mathrm{H}_{2} \mathrm{O}_{2}$. This report particularly stressed the idea that organic group modification on silica, SBA-15, can significantly affect the structure, stability and catalytic performance of the catalysts. A bifunctionalized mesoporous silica containing Bronsted acid and basic sites together on the surface has been prepared via post-synthetic modification route. ${ }^{113}$ At first a chloro substitute was prepared using 3-(chloropropyl)triethoxysilane which undergoes $S_{N} 2$ substitution with the amine group of 5aminoisophthalic acid under refluxing conditions in the presence of an excess base. The material preserved the ordered mesostructure with a surface area of $652 \mathrm{~m}^{2} \mathrm{~g}^{-1}$ after incorporating the acid and basic sites. The strength of acid sites was estimated by temperature-programmed desorption (TPD) of ammonia and found to be $1.94 \mathrm{mmol} \mathrm{g}^{-1}$. The basicity was determined quantitatively by acid-base titration to be 0.56 $\mathrm{mmol} \mathrm{g}^{-1}$. The prepared catalyst was explored for the conversion of carbohydrates to hydroxymethylfurfural (HMF) as a potential candidate for the synthesis of biofuels. A $74 \mathrm{~mol} \%$ conversion of fructose to HMF was observed under microwaveassisted heating at $135{ }^{\circ} \mathrm{C}$. The basic sites favor the isomerization and the acid sites are essential for the dehydration of fructose molecules. The same reaction was also applied to different carbohydrates like glucose, mannose, galactose, cellulose and starch.

\section{Heteroatom incorporation in SBA-15}

\subsection{Incorporation of heteroatoms as single-sites within the silica framework}

Homogeneous catalysts often involve the presence of transition metal centers surrounded by ligand environment whereas heterogeneous catalysts are mostly surface species which are sometimes difficult to characterize and understand at the molecular scale to build structure-reactivity relationships. Single-site heteroatom incorporated catalysts can form the bridge to fulfill the limitations between the two field of catalysis and hence are significantly important to have a deeper understanding and synthesis control of such type of materials. ${ }^{114-117}$ Mesoporous silica materials in the restricted and confined framework are suitable for incorporating metal atoms and complexes to design 'single-site photocatalyst' materials. ${ }^{118}$ The design of such materials can be realized by considering the coordination of active site, size, the shape of pores and their uniform distribution within the framework. They are promising nanostructured materials for single-site catalysts because of the following reasons; (i) easy adsorption and concentration of reactants in the pore structure, (ii) large surface area facilitating the active sites on surface, (iii) small amount of heteroatom largely influencing the surface properties, (iv) light transparency allowing the light penetration inside the pores and $(v)$ altering the pore spaces by changing the reaction environment. ${ }^{82,119-122}$

Metal oxide species such as $\mathrm{Ti}, \mathrm{V}, \mathrm{Cr}$ and Mo-oxide which are isolated and tetrahedral in geometry and incorporated within the silica framework are called single-site photocatalyst. Table 3 summarizes the single-site catalytic systems that has been briefly discussed in this section. The conventional $\mathrm{TiO}_{2}$ semiconductor photocatalyst form holes and electrons in the valence and conduction band, respectively, upon UV-light irradiation. These charge carriers can efficiently carry out the redox reaction by reacting with electron donor and acceptors adsorbed on its surface. However, in the case of single site Tioxide catalyst, the charge carriers form at a much closer distance attributing to the ligand to metal charge transfer (LMCT) process from oxygen $\left(\mathrm{O}^{2-}\right)$ to metal $\left(\mathrm{M}^{\mathrm{n}+}\right)$ ions as shown in Fig. 3. This charge-transfer excited state under UV-light irradiation exhibits unique photocatalytic activities. The formation of tetrahedrally coordinated Ti-oxide moieties can be characterized by ESR, UV-vis, photoluminescence and EXAFS analysis. An intense single peak in the XANES spectra at $4967 \mathrm{eV}$ is usually observed for single-site Ti-oxide, in comparison to several peaks for $\mathrm{TiO}_{2}$ in an octahedral environment. ${ }^{123,124,133}$ These Ti-mesoporous silica-based catalysts were reported to be active for $\mathrm{CO}_{2}$ reduction with $\mathrm{H}_{2} \mathrm{O}$ to form methane and methanol. They were also found to be active in the selective reduction of $\mathrm{NO}$ to $\mathrm{N}_{2}$ under UV-light irradiation. Other singlesite species like $\mathrm{V}, \mathrm{Cr}$ and $\mathrm{Mo}$ in tetrahedral geometry can absorb light in the visible region and hence can carry out photocatalytic reactions under visible light irradiation. Our group has studied the synthesis and characterization of singlesite photocatalysts using different types of silica including MCM-41, SBA-15 and HMS, which were employed in the variety of different catalytic reactions. ${ }^{125-128}$ Since the main theme of this review paper is focused on mesoporous silica, SBA-15, we will briefly mention some of the applications recently demonstrated.

\subsubsection{Fe-based single-site incorporation within the silica framework}

Designing active sites with detailed characterization is significant to demonstrate structure-reactivity relationships in heterogeneous catalysts. Tilley et al. explore the synthesis of single-site catalysts with isolated $\mathrm{Fe}$ species within the framework of mesoporous silica by using $\mathrm{Fe}$ (III) complex (tris(tert-butoxy)siloxy iron (III), Fe[OSi( $\left.\left.\left.\mathrm{O}^{\mathrm{t}} \mathrm{Bu}\right)_{3}\right]_{3}\right) .{ }^{129} \mathrm{SBA}-15$ was selected to introduce stable iron species because of its high surface area and presence of surface hydroxyl groups. The Fe complex reacts with the surface hydroxyl groups to form $\equiv \mathrm{Si}-\mathrm{O}$ $\mathrm{Fe}-\left[\mathrm{OSi}\left(\mathrm{O}^{\mathrm{t}} \mathrm{Bu}\right)_{3}\right]_{2}$ which removes the organic part upon calcination at $300{ }^{\circ} \mathrm{C}$ to form thermally stable isolated $\mathrm{Fe}$ (III) species. The successful incorporation of Fe species in SBA-15 was then investigated for selective oxidation of hydrocarbons using $\mathrm{H}_{2} \mathrm{O}_{2}$ as the oxidant. For example, $100 \%$ selectivity for phenol and benzaldehyde was obtained for benzene and benzyl alcohol oxidation reaction, respectively at $60^{\circ} \mathrm{C}$. The obtained TOF values were found to be higher than other related Fe-based 
heterogeneous catalysts. The higher catalytic activities were associated due to the presence of isolated and pseudotetrahedral Fe(III) species within the silica framework.

\subsubsection{Co-based single-site incorporation within the silica framework}

Zhao's research group also investigated the popular epoxidation reaction on single-site Co-based catalysts within the framework of mesoporous silica, SBA-15. ${ }^{131}$ The catalyst was synthesized by a $\mathrm{pH}$-adjusting method in which Co (II) species were incorporated tetrahedrally within the framework of silica to form Co-SBA-15. Other research groups have also investigated the synthesis of Co-SBA-15 using $\mathrm{NaOH}$ to adjust the $\mathrm{pH}$ of gel. ${ }^{132}$ Zhao et al. have tried the synthesis using $\mathrm{NH}_{3}$ and investigated for the epoxidation of styrene with $\mathrm{O}_{2}$ as the oxidant. The structure was confirmed by various characterization techniques including XRD, UV-vis, TPR, XPS and $\mathrm{N}_{2}$ physisorption analysis. The absorbance at 580 and $650 \mathrm{~nm}$ confirmed the tetrahedral coordination of $\mathrm{Co}^{2+}$ within the framework of SBA-15. The $\mathrm{Co}^{2+}$ content was found to significantly increase on increasing the Co content in the synthesis procedure. A maximum conversion of $94 \%$ was obtained in styrene epoxidation with $65 \%$ selectivity for the epoxide at $373 \mathrm{~K}$ for $8 \mathrm{~h}$. This performance was superior to using Co/MCM-41 and Co/SBA-15 as the catalysts, displaying the significance of single-site $\mathrm{Co}^{2+}$ species incorporated in SBA-15. Raman spectra of Co/SBA-15 and Co/MCM-41 displayed Co-O band arising from the strong interaction with silica surface, however, no band was observed for Co(II)-SBA-15 and Co(II)MCM-41, indicating the presence of highly dispersed cobalt species. The catalyst was found to be stable and reused up to 7 cycles without changing the conversion and selectivity values.

There are reports based on synthesizing single-site catalysts on the surface of silica by interacting with surface hydroxyl groups. In one study reported by Sun et al., quasi single (QS) Co sites were prepared with Co-O-Si bonds within SBA-15 without any aggregated $\mathrm{CO}_{3} \mathrm{O}_{4}$ species. ${ }^{138}$ They employed SBA-15 with a template before calcination which was proven to contain rich hydroxyl groups and confined nanospace favoring the synthesis of quasi single Co sites on SBA-15 as shown in Fig. 5(A). The preservation of mesoporosity of the prepared material by measuring XRD, $\mathrm{N}_{2}$ physisorption (Fig. 5 (B)). These catalysts were found to display superior catalytic performances in phenol (an organic pollutant) degradation than catalysts with aggregated species. Fig. $\mathbf{5}$ (C) displays the superior catalytic performance of 3.0 QS-CoS in higher pH solution degrading 100 $\%$ phenol within $5 \mathrm{~min}$. Fig. 5 (D) displays the HAADF-STEM image of 3.0 QS-CoS along with EDX mapping which also confirms the regular mesoporous structure with no particle formation.

3.1.3 Zr-based single-site incorporation within the silica framework
In another report, Zhang et al. have used the ligand-tailored approach to prepare zirconium complex modified single-site catalysts for cyanosilylation of benzaldehyde. Prior to modification, the SBA-15 was dehydroxylated by heating under vacuum conditions at $500{ }^{\circ} \mathrm{C}$. Following this, $\mathrm{Zr}$ complex, cyclopentadiene and O-donor ligand were dispersed onto SBA15 under inert reaction conditions. In situ FT-IR spectra was measured to assign vibrational peaks arising from different groups. The highest product yield of $95 \%$ was obtained which could be reused up to 5 cycles. This approach has been extended to $\mathrm{Ti}$ species deposition on commercial silica to prepare efficient single-site catalysts. ${ }^{134,135}$

In a recent study addressed by Ko's group, Zr-based single site catalysts from ( $n-\mathrm{BuCp})_{2} \mathrm{ZrCl}_{2}$ were prepared by the postsynthesis grafting method on the surface-functionalized SBA$15 .{ }^{140}$ The SBA-15 surface was modified by electron-donating groups like amine or nitrile group to enhance the interaction between $\mathrm{Zr}$ and silica surface. The $\mathrm{Zr}$ amount was found to be strongly dependent on the nitrogen content of the silica surface. The catalysts displayed superior performance for the polymerization of ethylene and ethylene-1-hexene because of the electron donating effect of functionalized group towards ( $n$ BuCp) ${ }_{2} \mathrm{ZrCl}_{2}$. The formation of more regular and large-sized particles also contributed to the superior activities of functionalized SBA-15. As an alternative application, mesoporous silica-supported amines are one of the classic examples for post-combustion capture of $\mathrm{CO}_{2}$ because of their outstanding capture ability at low temperatures. The tunable porous structure of silica can be utilized to dope heteroatom ( $\mathrm{Al}, \mathrm{Ti}, \mathrm{Ce}, \mathrm{Zr}$ ) within the matrix to create active sites that can further assist in the $\mathrm{CO}_{2}$ adsorption. ${ }^{142,143}$

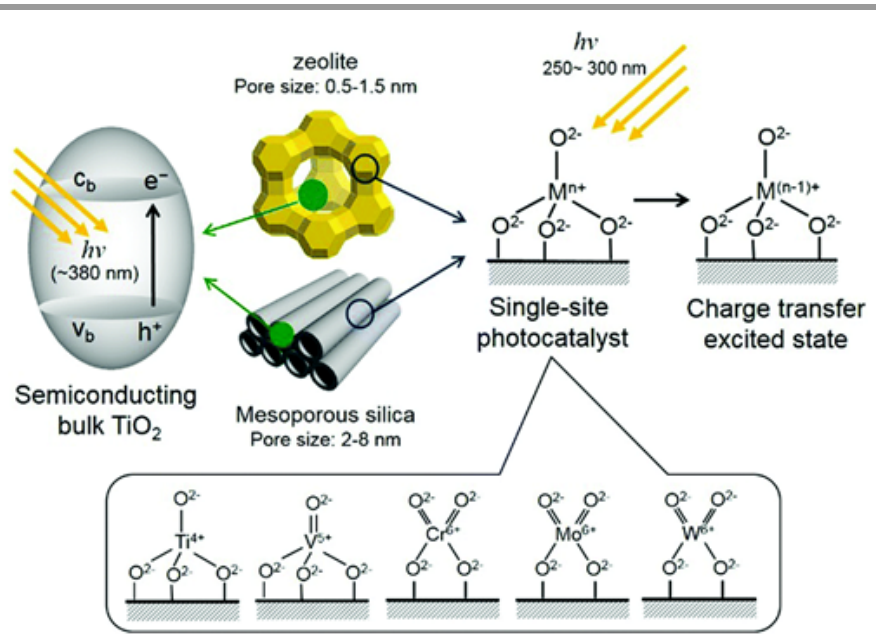

Fig. 3. Titanium oxide photocatalysts from bulk $\mathrm{TiO}_{2}$ to isolated Ti-oxide molecular species within the mesoporous silica and the formation of charge-transfer excited state with tetrahedrally coordinated metal oxide species under UV-light irradiation. Reproduced with permission from ref. [82] Copyright 2018 The Royal Society of Chemistry. 
(A)

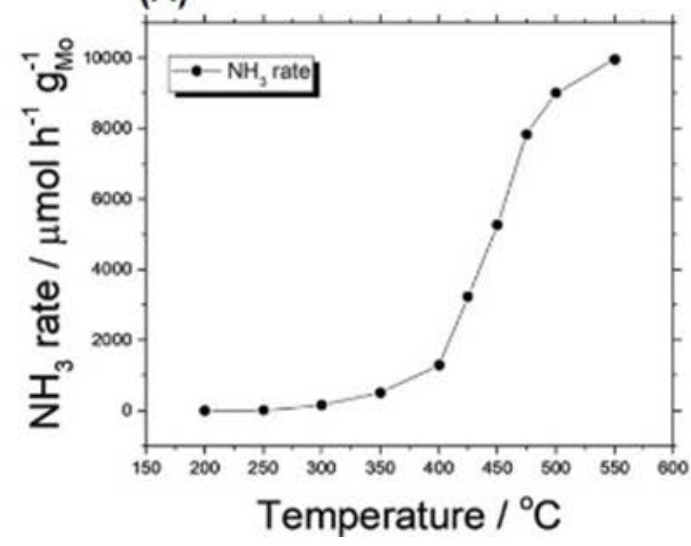

(B)

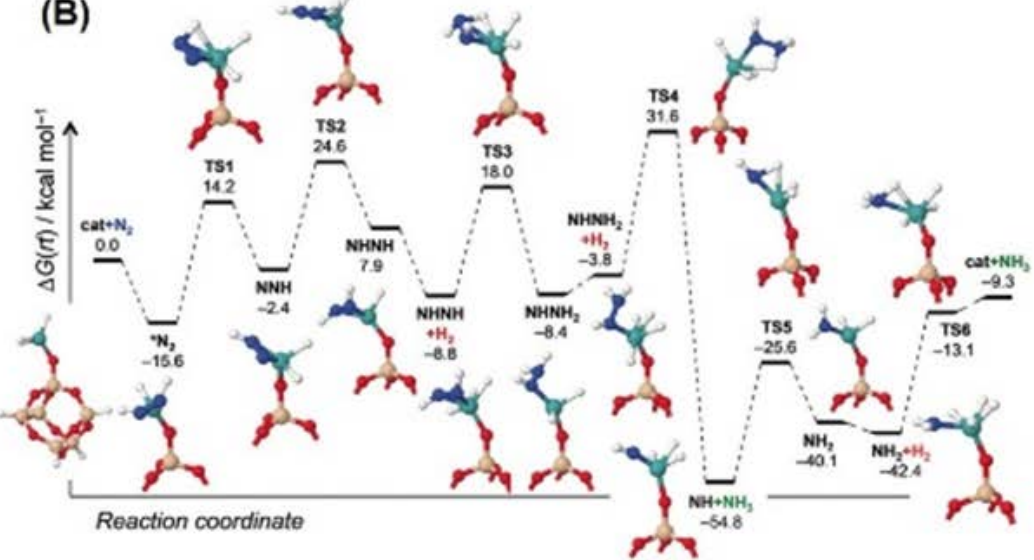

Fig. 4. (A) Rate of $\mathrm{NH}_{3}$ synthesis at different temperatures from $200-550{ }^{\circ} \mathrm{C}$ in $1 \mathrm{~h}$ interval, (B) Gibbs free energy profile for $\mathrm{N}_{2}$ to $\mathrm{NH}_{3}$ reaction mechanism at room temperature catalyzed by monopodal [( $\left.\equiv \mathrm{Si}-\mathrm{O}-) \mathrm{Mo}^{\prime V} \mathrm{H}_{3}\right]$. The silica model was represented by $\mathrm{Si}_{6} \mathrm{O}_{10} \mathrm{H}_{5}$. Reaction conditions: catalyst $20 \mathrm{mg}$, flow rate: $40 \mathrm{~mL}$ min-1, 3:1 $\mathrm{H}_{2}: \mathrm{N}_{2}$ ratio, $\mathrm{P}=1$ atm. Reproduced with permission from ref. [137] Copyright 2018 Wiley-VCH.

Table 3. Catalytic systems with heteroatoms doped as single-site within mesoporous silica

\begin{tabular}{|c|c|c|c|c|c|c|c|c|c|}
\hline \multirow{2}{*}{$\begin{array}{l}\text { Descriptor } \\
\text { (Single- } \\
\text { site } \\
\text { Metal) }\end{array}$} & \multirow{2}{*}{$\begin{array}{c}\text { Sub- } \\
\text { descriptor }\end{array}$} & \multicolumn{3}{|c|}{$\begin{array}{c}\text { Physicochemical } \\
\text { properties }\end{array}$} & \multirow[b]{2}{*}{ Reaction type } & \multirow[b]{2}{*}{$\begin{array}{l}\text { Catalytic } \\
\text { reaction }\end{array}$} & \multirow[b]{2}{*}{$\begin{array}{l}\text { Reaction } \\
\text { conditions }\end{array}$} & \multirow[b]{2}{*}{$\begin{array}{c}\text { Catalytic } \\
\text { performance }\end{array}$} & \multirow[b]{2}{*}{ Ref. } \\
\hline & & $\begin{array}{l}\text { Surface } \\
\text { area } \\
\left(\mathrm{m}^{2} / \mathrm{g}\right) \\
\end{array}$ & $\begin{array}{l}\text { Pore } \\
\text { size } \\
(\mathrm{nm}) \\
\end{array}$ & $\begin{array}{c}\text { Pore } \\
\text { volume } \\
\left(\mathrm{cm}^{3} / \mathrm{g}\right)\end{array}$ & & & & & \\
\hline Fe-SBA-15 & $\begin{array}{c}\text { Complexing } \\
\text { agent }\end{array}$ & -- & -- & -- & Oxidation & $\begin{array}{l}\text { Selective } \\
\text { oxidation of } \\
\text { benzene and } \\
\text { benzyl alcohol } \\
\text { using } \mathrm{H}_{2} \mathrm{O}_{2}\end{array}$ & $\begin{array}{l}\text { Substrate: } \\
18.5-22.4 \\
\text { mmol, } \\
\text { catalyst:130 } \\
\mathrm{mg}, \mathrm{H}_{2} \mathrm{O}_{2} 4000 \\
\mu \mathrm{mol}, \mathrm{CH}_{3} \mathrm{CN}: 5 \\
\mathrm{~mL}, \mathrm{t}=24 \mathrm{~h}, \mathrm{~T}= \\
25-60^{\circ} \mathrm{C}\end{array}$ & $\begin{array}{c}100 \% \\
\text { selectivity, } \\
\text { TOF }=2.5 \mathrm{X} \\
10^{-3} \text { and } 1.2 \\
\times 10^{-2}\end{array}$ & 129 \\
\hline \multirow[b]{2}{*}{ Ti-SBA-15 } & $\begin{array}{l}\text { Steric } \\
\text { effects }\end{array}$ & -- & -- & -- & Polymerisation & $\begin{array}{l}\text { Ethylene } \\
\text { polymerisation }\end{array}$ & $\begin{array}{l}\mathrm{T}=25^{\circ} \mathrm{C}, \mathrm{t}=10 \\
\min \end{array}$ & $\begin{array}{c}28.7 \mathrm{~kg} \\
\mathrm{PE} / \mathrm{mol} \mathrm{Ti} \cdot \mathrm{h}\end{array}$ & 139 \\
\hline & $\begin{array}{l}\text { Thermal } \\
\text { stability }\end{array}$ & 300 & 5.6 & 0.38 & Epoxidation & $\begin{array}{l}\text { Epoxidation of } \\
\text { cyclohexene, } \\
\text { CHP oxidant }\end{array}$ & $\begin{array}{l}\mathrm{T}=65^{\circ} \mathrm{C}, \\
\text { Cumene } \\
\text { hydroperoxide } \\
\text { (CHP) as } \\
\text { oxidant }\end{array}$ & TOF $=643$ & 130 \\
\hline \multirow{4}{*}{ Zr-SBA-15 } & $\begin{array}{l}\text { Electron } \\
\text { donating } \\
\text { groups }\end{array}$ & 665 & 5.8 & 0.99 & Polymerisation & $\begin{array}{l}\text { Ethylene } \\
\text { polymerisation }\end{array}$ & $\begin{array}{l}\mathrm{T}=70^{\circ} \mathrm{C}, \mathrm{P}=7 \\
\text { bar, } \mathrm{t}=0.5 \mathrm{~h}, \\
\text { catalyst }=200 \\
\mathrm{mg}\end{array}$ & $\begin{array}{c}0.38 \mathrm{~kg} \mathrm{PE} / \mathrm{g}- \\
\text { cat } \cdot \mathrm{h}\end{array}$ & 140 \\
\hline & $\begin{array}{l}\text { Ligand } \\
\text { approach }\end{array}$ & 558 & 6.4 & 0.89 & Cyanosilylation & $\begin{array}{l}\text { Cyanosilylation } \\
\text { of benzaldehyde }\end{array}$ & $\begin{array}{l}\text { Substrate }= \\
1 \mathrm{mmol} \text { in } 20 \\
\mathrm{~mL} \text { Toluene, } \mathrm{t}= \\
12 \mathrm{~h} \text { at RT }\end{array}$ & $\begin{array}{c}100 \% \\
\text { conversion }\end{array}$ & 134 \\
\hline & $\begin{array}{c}\mathrm{CO}_{2} \\
\text { adsorption }\end{array}$ & 230 & 7.8 & 0.61 & Adsorption & $\begin{array}{l}\text { Amine } \\
\text { functionalized } \\
\text { for } \mathrm{CO}_{2} \text { capture }\end{array}$ & $\begin{array}{l}\mathrm{T}=25^{\circ} \mathrm{C} \text { under } \\
\text { dry conditions, } \\
t=12 \mathrm{~h}\end{array}$ & $\begin{array}{lr}0.85 \quad \mathrm{mmol}^{2} \\
\mathrm{CO}_{2} \quad \mathrm{~g}^{-1} \\
\text { 400ppm } \mathrm{CO}_{2} \\
\text { with } \mathrm{Ar}\end{array}$ & $\begin{array}{l}142, \\
143\end{array}$ \\
\hline & Acidity & 515 & 5.0 & 0.56 & Esterification & $\begin{array}{l}\text { Esterification to } \\
\text { produce } \\
\text { biofuels }\end{array}$ & $\begin{array}{l}\mathrm{T}=70^{\circ} \mathrm{C}, \mathrm{t}=24 \\
\mathrm{~h} \text { at } 700 \mathrm{rpm}, \\
\text { solvent= EtOH }\end{array}$ & $\begin{array}{l}79 \% \text { yield } \\
\text { ethyl } \\
\text { levulinate }\end{array}$ & 144 \\
\hline Co-SBA-15 & $\begin{array}{l}\text { Oxidation } \\
\text { state }\end{array}$ & 298 & 13.8 & 1.03 & Epoxidation & $\begin{array}{l}\text { Epoxidation of } \\
\text { styrene using } \mathrm{O}_{2}\end{array}$ & $\begin{array}{l}\mathrm{T}=100^{\circ} \mathrm{C}, \mathrm{t}=8 \\
\mathrm{~h}, \mathrm{O}_{2}=15\end{array}$ & $\begin{array}{l}94 \quad \% \\
\text { conversion, }\end{array}$ & 131 \\
\hline
\end{tabular}




\begin{tabular}{|c|c|c|c|c|c|c|c|c|c|}
\hline & & & & & & & $\begin{array}{l}\mathrm{ml} / \mathrm{min}, \\
\text { catalyst }=0.3 \mathrm{~g}\end{array}$ & $\begin{array}{l}65 \% \text { epoxide } \\
\text { selectivity }\end{array}$ & \\
\hline \multirow[t]{2}{*}{$\begin{array}{c}\text { Mo-SBA- } \\
15\end{array}$} & $\begin{array}{c}\text { mixed } \\
\text { metal } \\
(\mathrm{Mo} / \mathrm{V})\end{array}$ & 327 & -- & -- & Oxidation & $\begin{array}{l}\text { Dehydrogenatio } \\
\mathrm{n} \text { of propane }\end{array}$ & $\mathrm{T}=420^{\circ} \mathrm{C}$ & $\begin{array}{l}10 \% \text { acrolein } \\
\text { selectivity } \\
(\mathrm{Mo} / \mathrm{V}=10)\end{array}$ & 136 \\
\hline & precursor & -- & -- & -- & Reduction & $\begin{array}{c}\mathrm{N}_{2} \text { reduction to } \\
\text { ammonia }\end{array}$ & $\begin{array}{l}\mathrm{T}=400{ }^{\circ} \mathrm{C}, \mathrm{P}=1 \\
\text { atm, flow rate } \\
40 \mathrm{ml} / \mathrm{min}, 3: 1 \\
\mathrm{H}_{2}: \mathrm{N}_{2} \text { ratio }\end{array}$ & $\begin{array}{l}3500 \mu \mathrm{mol} \mathrm{h}^{-} \\
{ }^{1} \mathrm{~g}_{\mathrm{Mo}^{-1} \mathrm{NH}_{3}}\end{array}$ & 137 \\
\hline
\end{tabular}

SBA-15 silica was impregnated with low molecular weight branched poly(ethyleneimine) (PEI) amine source which has accessible primary amine sites on chain ends. Heteroatoms are believed to be effective in creating amine-stabilizing sites. The catalyst materials were prepared by a simple impregnation of $\mathrm{PEI}$ onto the M-SBA-15 and retained their ordered mesoporosity and pore volumes after impregnation. Fig. 6 (A, B) displays the TEM images along with pore size distribution of SBA-15 and Zr-SBA-15, confirming the ordered hexagonal arrangement and uniform pore sizes required for adsorption. The adsorption capacity varied on changing the concentration and type of metal species doped within the framework. Zr-SBA15 with $\mathrm{Zr} / \mathrm{Si}$ content of 0.07 displayed a maximum adsorption capacity of $0.86 \mathrm{mmol} \mathrm{CO}_{2} \mathrm{~g}^{-1}$ followed by Ce-SBA-15 and TiSAB-15. The superior performance of $\mathrm{Zr}-\mathrm{SBA}-15$ was attributed to the uniform incorporation of $\mathrm{Zr}$ in the silica framework in comparison to $\mathrm{Ce}$ and $\mathrm{Ti}$ where $\mathrm{CeO}_{2}$ and $\mathrm{TiO}_{2}$ phases were also present. However, the inclusion of higher contents of $\mathrm{Zr}$ in the silica led to the reduced $\mathrm{CO}_{2}$ uptake which can be attributed to the poor structural properties such as decreased surface area, porosity, etc. Fig. 6 (C) displays that PEI/SBA-15 lost $34 \%$ of its original adsorption capacity and PEI/Zr-SBA-15 adsorbed $\mathrm{CO}_{2}$ reversibly with maintaining the overall adsorption capacity after 4 cycles. It was proposed that such silica-based adsorbents with optimal doping of $\mathrm{Zr}(\mathrm{Zr} / \mathrm{Si} \sim 0.07)$ offer strong interactions between $\mathrm{PEI}$ and $\mathrm{Zr}$ species and enhance the thermal stability and regenerability with increased efficiency of amines to capture $\mathrm{CO}_{2}$. All catalysts also retained its mesoporosity after the adsorption and hence can act as the promising candidates for practical $\mathrm{CO}_{2}$ capture applications.

Various kinds of solid acid catalysts have been reported for the esterification reaction to produce biofuels. Our group has reported the synthesis of sulfated Zr-SBA-15 which was used for the esterification of levulinic acid with ethanol to form ethyl levulinate. Levulinate esters are useful as fuel additives, solvents and can directly be used up to $5 \mathrm{wt} \%$ as diesel miscible biofuel. Sulfated Zr-SBA-15 displayed superior catalytic performances than the conventional sulfated $\mathrm{ZrO}_{2} \cdot{ }^{144} \mathrm{The}$ surface area and pore volume of SBA-15 decreased from 848 $\mathrm{m}^{2} \mathrm{~g}^{-1}$ and $1.56 \mathrm{~cm}^{3} \mathrm{~g}^{-1}$ to $515 \mathrm{~m}^{2} \mathrm{~g}^{-1}$ and $0.56 \mathrm{~cm}^{3} \mathrm{~g}^{-1}$ on $\mathrm{Zr}$ incorporation with $\mathrm{Si} / \mathrm{Zr}$ ratio of 10.7 , respectively. With higher $\mathrm{Zr}$ loadings, the mesoporous silica tends to degrade leading to a reduced mesoporosity. Optimal doping of $\mathrm{Zr}$ in the framework leads to the maximum product yield of $79 \%$ at $70{ }^{\circ} \mathrm{C}$ after $24 \mathrm{~h}$ of reaction time. The catalytic activity was correlated better with acid density more than the number of acid sites present in the catalyst. However, a decrease in the activity was observed for recycling experiments because of the leaching of $\mathrm{SO}_{4}{ }^{2-}$ ions in the alcohol medium. Aside from these, some recently reported works on single-site catalysts involving $\mathrm{Zr}, \mathrm{Cu}-\mathrm{Mg}, \mathrm{Pd}$ $\mathrm{C}, \mathrm{Mn}$ and Ti incorporated within the framework of SBA-15 have also been reported. ${ }^{145-151}$

\subsubsection{Mo-based single-site incorporation within the silica framework}

A very recent report by Trunschke's group studied the reactivity of molybdenum and vanadium metal oxides present in larger contents versus single-site for the selective oxidation reaction of propane. ${ }^{136}$ This mixed metal oxide supported on chemically inert mesoporous silica, SBA-15, was designed to study the mutual interaction of $\mathrm{Mo}$ and $\mathrm{V}$ present together in a monolayer with a Mo/ $\mathrm{V}$ ratio ranging from 10 and 1 . The Mo-V monolayer on the surface was prepared by two consecutive steps using limited amounts of ammonium heptamolybdate tetrahydrate and vanadium oxytriethoxide as the precursor solutions. The oxidative dehydrogenation of propane to acrolein was investigated at $673 \mathrm{~K}$. The best activity was displayed by MoV/SBA-15 (Mo/V = 10) with $10 \%$ acrolein selectivity. It was concluded that isolated $\mathrm{V}$ or Mo species exhibit improved acrolein selectivity because of the larger amount of electrophilic oxygen species. The existence of Mo on silica was mainly in the form of dioxo species $(\mathrm{Si}-\mathrm{O}-)_{2} \mathrm{Mo}(=\mathrm{O})_{2}$ and mixing of vanadium species with Mo prevents the $\mathrm{V}-\mathrm{O}-\mathrm{V}$ bond formation. The interaction between single vanadyl sites and the adjacent Mo sites is not strong, therefore the rate of oxidation reaction is very low in comparison to the bulk catalyst. However, the slow reaction rate facilitated the selectivity towards acrolein formation.

Another report on the Mo incorporation from Basset's group reports the low loading amounts of single-site Mo hydride species on silica for $\mathrm{N}_{2}$ reduction to $\mathrm{NH}_{3}$. The Mohydrides were synthesized from monopodal Mo-neopentyl precursor $\left[(\equiv \mathrm{Si}-\mathrm{O}-) \mathrm{Mo}\left(\equiv \mathrm{C}-\mathrm{t}^{\mathrm{B} u}\right)(\mathrm{Np})_{2}\right]$ at $300{ }^{\circ} \mathrm{C} .{ }^{137}$ It was observed that the rate of $\mathrm{NH}_{3}$ production increases on increasing the temperature with $1276 \mu \mathrm{mol} \mathrm{h}^{-1} \mathrm{gMo}^{-1} \mathrm{NH}_{3}$ at $400^{\circ} \mathrm{C}$ at an atmospheric pressure as shown in Fig. 4(A). To understand the mechanistic events occurring during reaction, DFT modeling was carried out. It was observed that $N_{2}$ gas is chemisorbed on the Mo centre with a Gibbs free energy of -15.6 kcal mol-1 as depicted in Fig. 4(B). Based on the calculations of 
all steps, the authors proposed that $\mathrm{MoH}_{\mathrm{x}}$ follows a non-distal associative mechanistic route for the conversion of $\mathrm{N}_{2}$ to $\mathrm{NH}_{3}$.

\subsubsection{Ti-based single-site incorporation within the silica framework}

Jones's group studied the designing of organometallic Tibased single-site catalysts isolated on the surface of aminefunctionalized silica by a new patterning methodology. In this approach, silica surface is at first functionalized by primary amine groups that can act as the scaffolds for the assembly of well-defined and isolated complexes on the surface. The constraint geometry catalysts (CGCs) are prepared by the stepwise loading of the organometallic complex on support material which causes the generation of multiple sites and leads to steric crowding on the support. Such Ti-SBA-15 based CGCs catalysts were found to be 10 times more active for ethylene polymerization than multisited catalysts prepared by traditional covalently anchored techniques due to the isolated nature of the sites. ${ }^{139}$

The single-site Ti-oxide moieties were incorporated within the channels of the SBA-15 and were modified by grafting of triethoxyfluorosilane (TEFS) as the silylation reagent. ${ }^{141}$ TEFSmodified Ti-SBA-15 displayed much higher catalytic performances in the epoxidation of cyclooctene to 1,2epoxycyclooctane using $\mathrm{H}_{2} \mathrm{O}_{2}$ as the oxidant than the unmodified Ti- SBA-15. 5 wt \% loading of TEFS onto Ti-SAB-15 leads to the highest TON for the epoxidation reaction in comparison to $0.0,2.0,10$ and $20 \mathrm{wt} \%$ of TEFS modified Ti-SBA15. The enhanced catalytic performance was attributed to the improved hydrophobicity on the surface of Ti-SBA-15. Tilley et al. has also further explored the synthesis of single-site Ti-SBA15 and Ti-MCM-41 catalysts with a similar strategy of using different organic complexes to react with surface hydroxyl groups and forming isolated species after calcination at higher temperatures. ${ }^{130}$ The Ti-oxide moieties in tetrahedral coordination within the silica framework was tested for the enhanced catalytic performance in the epoxidation of cyclohexene. Ti-SBA-15 was also found to be superior than $\mathrm{Ti}$ MCM-41 with turn over frequencies ranging from 500-1500 $\mathrm{h}^{-1}$. This was attributed to the much higher thermal stability and highest coverage of isolated, tetrahedral Ti centers in SBA-15.

\subsection{Immobilization of metal nanoparticles within the pore channels}

Metal NPs immobilized on mesoporous silica have gained much popularity in the field of heterogeneous catalysis as the active and reusable catalysts for a variety of catalytic reactions. ${ }^{152-159}$ The SBA-15 support material facilitates the high dispersion of metal NPs and easy diffusion of substrate molecules to the active sites. The large surface area and 2D hexagonal mesoporous structure stabilize the metal species and prevent them from leaching and aggregation.
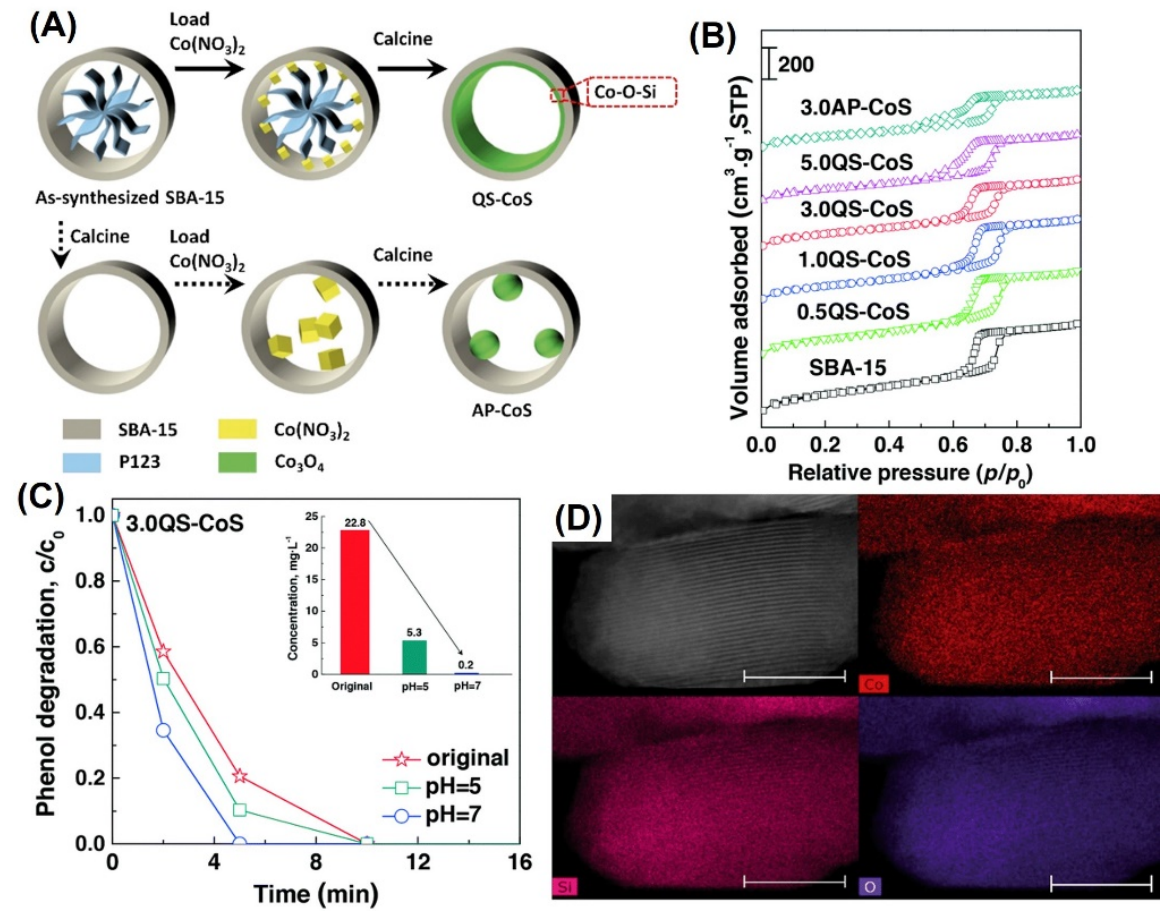

Fig. 5. (A) Quasi single cobalt sites and aggregated $\mathrm{CO}_{3} \mathrm{O}_{4}$ fabrication in the nanopores of $\mathrm{SBA}-15$, (B) $\mathrm{N}_{2}$ physisorption isotherms, (C) Degradation of phenol in constant pH value solution and (D) HAADF-STEM and elemental mapping of 3.0QS-CoS (Scale bars: $200 \mathrm{~nm}$ ). ([Catalyst $]_{0}=0.2 \mathrm{~g} \mathrm{~L}^{-1}$, [peroxymonosulfate $]_{0}=2.0 \mathrm{~g} \mathrm{~L}^{-1}$, [phenol $]_{0}=20 \mathrm{mg} \mathrm{L}^{-1}$ at $25{ }^{\circ} \mathrm{C}$. Reproduced with permission from ref. [138] Copyright 2018 The Royal Society of Chemistry 

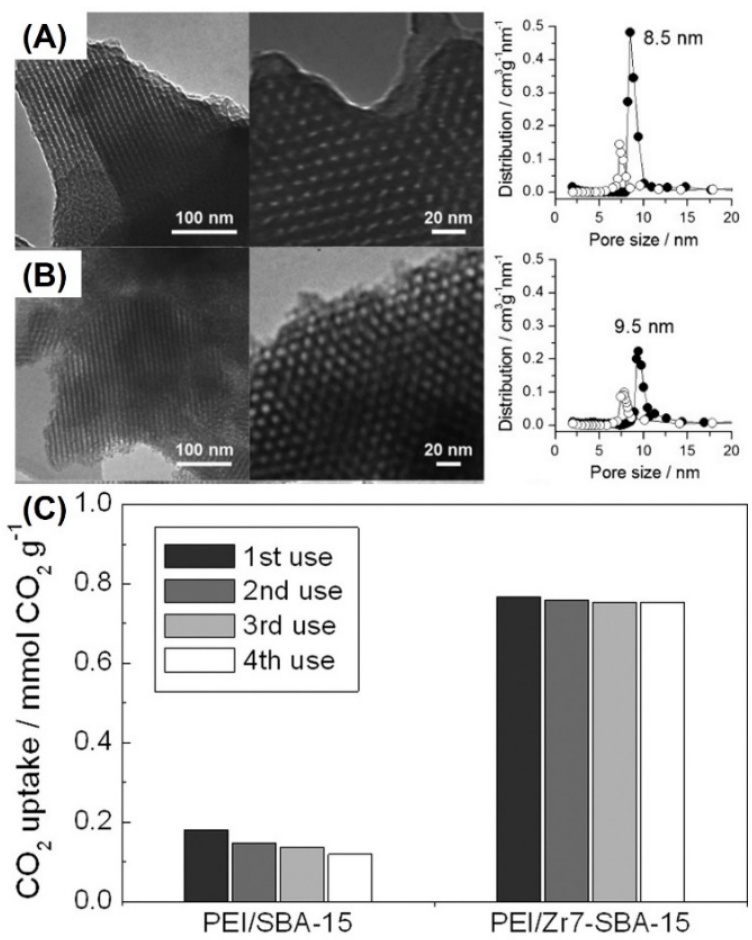

Adsorbents

Fig. 6. TEM images (side and top-view) and pore size distribution for (A) SBA-15, (B) ZrSBA-15. Reproduced with permission from ref. [143] Copyright $2012 \mathrm{Wiley-VCH}$. and (C) Temperature-swing multicycle $\mathrm{CO}_{2}$ adsorption-desorption testing of PEI/SBA-15 and $\mathrm{PEI} / \mathrm{Zr} 7-\mathrm{SBA}-15$. The $\mathrm{CO}_{2}$ adsorption capacity was measured at $25^{\circ} \mathrm{C}$ under dry conditions using simulated air $\left(400 \mathrm{ppm} \mathrm{CO}_{2}\right)$ and regeneration under Ar flow at $110^{\circ} \mathrm{C}$. Reproduced with permission from ref. [142] Copyright 2012 American Chemical Society.
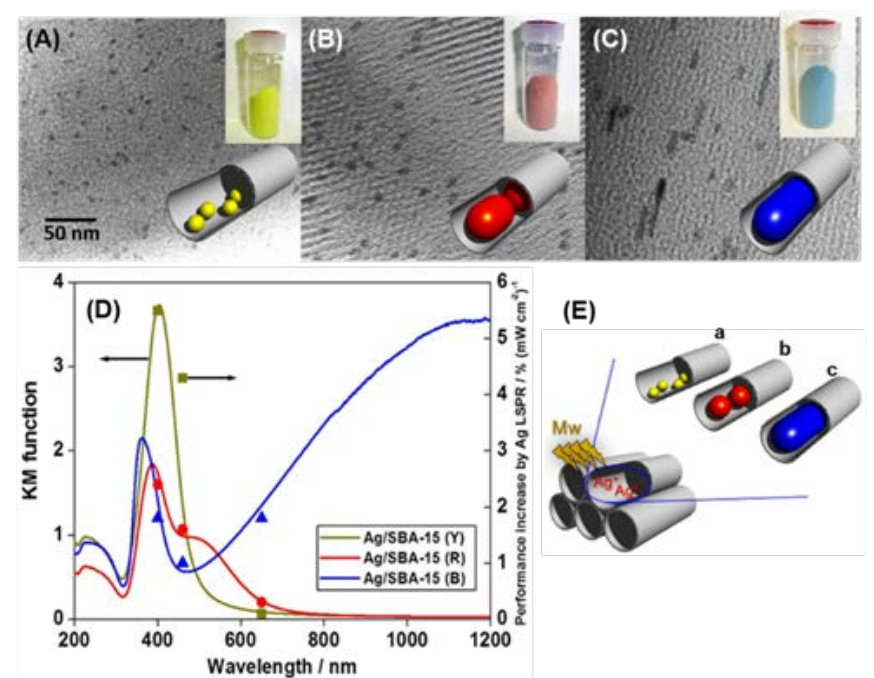

Fig. 7. TEM micrographs and photographs (insets) for (A) Ag/SBA-15 (Y), (B) Ag/SBA-15 (R), (C) Ag/SBA-15 (B), (D) UV-vis and wavelength dependence spectra and (E) Illustration of Ag NPs growth within the channels of mesoporous silica. Reproduced with permission from ref. [152] Copyright 2015 The Royal Society of Chemistry.
The different methods of preparation of NPs have significantly advanced in recent years with respect to controlling size, shape and morphology on SBA-15 support material. SBA-15 comes under the category of inert support material because of which the catalytic performance ability depends solely on the composition, size and morphology of NPs. The surface deposition of metal NPs on silica can be conventionally prepared by different methods as shown in Scheme 2; (1) impregnation of metal aqueous solution followed by reducing agent such as $\mathrm{H}_{2}$ or $\mathrm{NaBH}_{4}$, (2) deposition of colloidal suspension of metal NPs on SBA-15, (3) in situ incorporation of heteroatom during the synthesis of SBA-15 also known as co-precipitation and (4) microwave-assisted alcohol reduction method to deposit metal NPs within the mesoporous channels of silica. ${ }^{160-163}$ Using these methods of heteroatom incorporation, the framework structure of silica is usually remained unchanged which can be confirmed by a variety of characterization techniques, as will be discussed briefly in this section. A summary of different catalytic systems is shown in Table 4.

Our group has reported the synthesis of size and colorcontrolled Ag NPs within the mesoporous channels of silica, SBA-15. ${ }^{83,152,153}$ The NPs are prepared by controlling the irradiation time of microwave heating from 3 to 5 min leading to yellow, red and blue Ag NPs and nanorods. Fig. 7 (A-C \& E) displays the TEM micrograph and pictorial representation of three different morphologies of $\mathrm{Ag}$ represented as $\mathrm{Ag} / \mathrm{SBA}-15$ (Y), Ag/SBA-15 (R) and Ag/SBA-15 (B). The Ag/SBA-15 (B) blue nanorods were found to be grown parallel to the hexagonal mesoporous channels of SBA-15 with an aspect ratio of $6.1 \mathrm{~nm}$. The catalytic application was tested in the hydrogen production from ammonia borane. The small-sized Ag/SBA-15 (Y) displayed superior catalytic performance followed by $\mathrm{Ag} / \mathrm{SBA}-15(\mathrm{R})$ and Ag/SBA-15 (B). Under visible light irradiation $(\lambda>420 \mathrm{~nm})$, significant activity enhancements were observed owing to localized surface plasmon resonance (SPR) effect of Ag NPs. The enhancement followed the order; Ag/SBA-15 (B) > Ag/SBA-15 $(\mathrm{R})>\mathrm{Ag} / \mathrm{SBA}-15(\mathrm{Y})$. This trend can be related to the light absorption in the visible and infrared region of the spectrum as shown in Fig. 7 (D). Further, bimetallic combination of Ag with catalytically active metals ( $\mathrm{Pd}, \mathrm{Ru}, \mathrm{Pt}, \mathrm{Ni}, \mathrm{Co})$ was studied to explore enhanced catalytic activities with the assist of SPR effect of Ag NPs. ${ }^{160-164}$

Balan et al. reported the photo reduction of gold NPs on SBA-15 using free radical generator Irgacure 2959 for evaluating its efficiency in the benzyl alcohol oxidation reaction. A $51 \%$ conversion of alcohol with $91 \%$ selectivity for benzaldehyde at $100{ }^{\circ} \mathrm{C}$ for $4 \mathrm{~h}$ was obtained. The obtained results were found to be comparable of using Au NPs deposited on semiconductor $\mathrm{TiO}_{2}$ as a support material under visible light irradiations. ${ }^{159}$ 


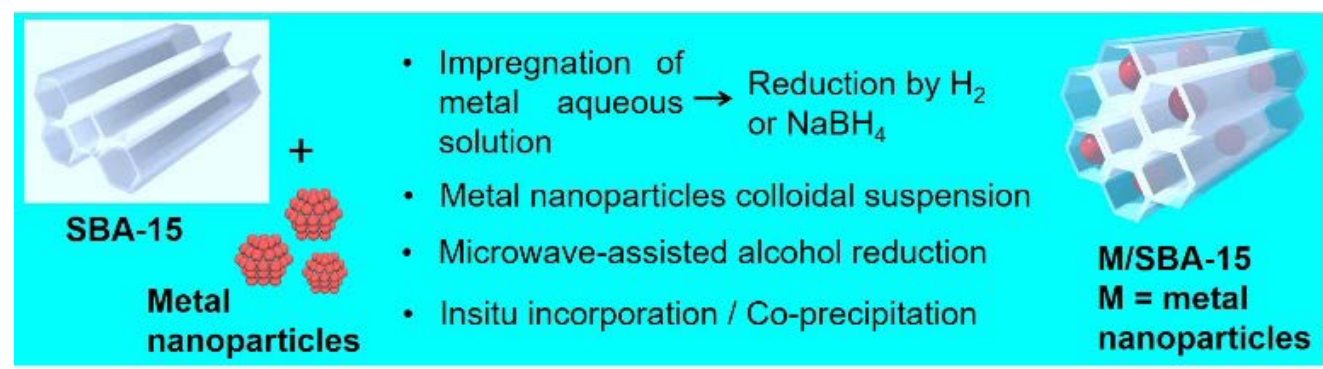

Scheme 2. Different methods of depositing metal nanoparticles on SBA-15.

Zhang et al. has reported Al-SBA-15 supported Ag catalysts for the selective oxidation of $\mathrm{CO}^{165}$ Al-incorporated mesoporous silica (aluminosilicate) have gained recent attention because of the presence of acidic and defect sites. AlSBA-15 framework led to the formation of highly dispersed Ag NPs displaying superior catalytic performances due to its octahedrally coordinated framework connected via oxygen atoms by suppressing the formation of $\mathrm{H}$-bonded $\mathrm{SiOH}$ groups. All Ag catalysts oxidized $\mathrm{CO}$ to $\mathrm{CO}_{2}$ with $98 \%$ conversion at $60^{\circ} \mathrm{C}$ and $\mathrm{Al}$-incorporated analog displayed similar conversions at $45^{\circ} \mathrm{C}$. A large amount of $\mathrm{Al}$ incorporation into the silica favored the formation of $\mathrm{Ag}_{2} \mathrm{O}$ species which led to a decrease in the overall activity of the catalyst.

Another interesting report published by Richards et al. carried out the intercalation of Pd NPs within the framework of SBA-15 (PdMS). ${ }^{166}$ Metal NPs often suffer from sintering or leaching, leading to stability issues. Silica support offers a stable and inert framework with tunable pore structure and mild acidity to encapsulate Pd NPs within the porous silica shell. A one-pot synthesis method using $\mathrm{PdCl}_{2}$ and a metal-directing agent was employed during the co-condensation process into the SBA-15. Pd encapsulation did not alter the ordered structure of SBA-15 and a slight decrease in the BET surface area was observed. XPS analysis revealed the presence of more oxidized Pd species in PdMS than in Pd/SBA-15 which was attributed to its proximity with silica leading to $\mathrm{Pd}-\mathrm{O}-\mathrm{Si}$ interactions. PdMS catalyst was catalytically active for the hydrodeoxygenation (HDO) reaction of phenol at higher temperature and pressure conditions. High-pressure conditions (from 10 to 30 bar) increased the conversions from 38 to $94 \%$ at $350{ }^{\circ} \mathrm{C}$, whereas low temperature was favorable for higher product selectivity (93\%) of cyclohexanol. Further, the PdMS catalyst could be easily regenerated which increased the lifetime and reduced the material cost for commercial applications.

A comparative research study has been performed for $\mathrm{Pt}$ NPs deposited on amine-functionalized SBA-15 and bare SBA15 for the catalytic reduction of bromate by hydrogen. ${ }^{167}$ Bromate $\left(\mathrm{BrO}_{3}{ }^{-}\right)$ions are the disinfection by-products formed by the treatment of wastewater containing bromide source products. The maximum permissible levels as stipulated by the World Health Organization (WHO) in drinking water is $0.01 \mathrm{mg} / \mathrm{L}$ because of its potential as carcinogens on the human body. Various physicochemical methods have been developed for bromate treatment in water such as reverse osmosis, ion exchange, electrodialysis and adsorption. In this report by Cui's group, a heterogeneous catalytic hydrogenation approach has been used to reduce bromate to bromide ions under mild reaction conditions. The average size of NPs in $4 \mathrm{wt} \% \mathrm{Pt} / \mathrm{SBA}-$ 15 and $\mathrm{Pt} / \mathrm{NH}_{2}$-SBA-15 was found to be 3.8-3.9 nm, depicting a similar dispersion of metal NPs in the presence or absence of amine functionalization. The amine functionalization significantly improved the bromate removal performance of 4 wt \% Pt/SBA-15 from $23.21 \mathrm{mg} \mathrm{min}^{-1} \mathrm{gcat}^{-1}$ to $32.87 \mathrm{mg} \mathrm{min}^{-1} \mathrm{~g}_{\mathrm{cat}}{ }^{-}$ 1 , respectively. This difference in the activity was justified by measuring the zeta potential at $\mathrm{pH}=7.0$ and the aminefunctionalized $\mathrm{Pt} / \mathrm{NH}_{2}$-SBA-15 exhibited a positive charge (4.21 $\mathrm{mV})$, while Pt/SBA-15 displayed a negative charge of $-22.05 \mathrm{mV}$. This might have resulted in an electrostatic attraction between the positively charged $\mathrm{NH}_{2}$-SBA-15 and bromate ions and hence leading to the enhanced catalytic reduction rates.

Table 4. Catalytic systems with metal NPs incorporated mesoporous silica

\begin{tabular}{|c|c|c|c|c|c|c|c|c|c|}
\hline \multirow{2}{*}{$\begin{array}{c}\text { Descriptor } \\
\text { (Metal } \\
\text { NPs) }\end{array}$} & \multirow[b]{2}{*}{ Sub-descriptor } & \multicolumn{3}{|c|}{ Physicochemical properties } & \multirow[b]{2}{*}{ Reaction type } & \multirow[b]{2}{*}{$\begin{array}{l}\text { Catalytic } \\
\text { reaction }\end{array}$} & \multirow[b]{2}{*}{$\begin{array}{l}\text { Reaction } \\
\text { conditions }\end{array}$} & \multirow[b]{2}{*}{$\begin{array}{c}\text { Catalytic } \\
\text { performan } \\
\text { ce }\end{array}$} & \multirow[b]{2}{*}{ Ref. } \\
\hline & & $\begin{array}{l}\text { Surfac } \\
\text { e area } \\
\left(\mathrm{m}^{2} / \mathrm{g}\right)\end{array}$ & $\begin{array}{l}\text { Pore } \\
\text { size } \\
(n m)\end{array}$ & $\begin{array}{c}\text { Pore } \\
\text { volume } \\
\left(\mathrm{cm}^{3} / \mathrm{g}\right)\end{array}$ & & & & & \\
\hline $\mathrm{Ag} / \mathrm{SBA}-15$ & $\begin{array}{l}\text { Morphology } \\
\text { controlled, } \\
\text { Microwave }\end{array}$ & 632 & 8.2 & 1.18 & $\begin{array}{l}\text { Dehydrogenat } \\
\text { ion }\end{array}$ & $\begin{array}{l}\mathrm{H}_{2} \text { generation } \\
\text { from }\end{array}$ & $\begin{array}{l}\text { Under Visible } \\
\text { light } \\
\text { irradiation, } \lambda\end{array}$ & $\begin{array}{l}100 \% \\
\text { conversion, }\end{array}$ & $\begin{array}{r}83 \\
152 \\
153 \\
\end{array}$ \\
\hline
\end{tabular}




\begin{tabular}{|c|c|c|c|c|c|c|c|c|c|}
\hline & $\begin{array}{l}\text { assisted } \\
\text { synthesis }\end{array}$ & & & & & $\begin{array}{l}\text { ammonia } \\
\text { borane }\end{array}$ & $\begin{array}{l}>420 \mathrm{~nm} \text { at } \\
\text { RT }\end{array}$ & $\begin{array}{l}0.94 \mathrm{~mol} \% \\
\mathrm{~min}^{-1}\end{array}$ & \\
\hline & $\begin{array}{l}\text { Acidic and } \\
\text { defect sites }\end{array}$ & 391 & 7.9 & 1.04 & Oxidation & $\begin{array}{l}\text { Selective } \\
\text { oxidation of } \\
\text { co }\end{array}$ & $\begin{array}{l}\text { Pre-treatment } \\
\text { with } \mathrm{O}_{2} \text { at } 500 \\
{ }^{\circ} \mathrm{C} \text { for } 2 \mathrm{~h}\end{array}$ & $\begin{array}{l}98 \% \\
\text { conversion }\end{array}$ & 165 \\
\hline & $\begin{array}{c}\text { Size-controlled } \\
\text { NPs }\end{array}$ & 621 & 7.0 & 0.9 & $\begin{array}{l}\text { Dehydrogenat } \\
\text { ion }\end{array}$ & $\begin{array}{l}\text { Hydrogen } \\
\text { production } \\
\text { from } \\
\text { ammonia } \\
\text { borane }\end{array}$ & $\begin{array}{l}\mathrm{T}=25^{\circ} \mathrm{C} \text { and } \\
\mathrm{P}=1 \mathrm{~atm}\end{array}$ & $\begin{array}{l}100 \% \\
\text { conversion, } \\
\text { TOF }=0.41 \\
\mathrm{~min}^{-1}\end{array}$ & 169 \\
\hline & $\begin{array}{c}\text { Bimetallic } \\
\text { combination } \\
\text { with Au }\end{array}$ & 800 & -- & -- & $\begin{array}{l}\text { Hydrogenatio } \\
n\end{array}$ & $\begin{array}{l}\text { Selective } \\
\text { hydrogenatio } \\
\text { n of butadiene }\end{array}$ & $\begin{array}{l}\mathrm{T}=120{ }^{\circ} \mathrm{C} \\
0.3 \% \\
\text { butadiene, } \\
30 \% \text { propene, } \\
20 \% \mathrm{H}_{2}, \text { flow } \\
\text { rate } \quad 50 \\
\mathrm{~mL} / \mathrm{min}\end{array}$ & $\begin{array}{l}\text { TOF }=5.6 \mathrm{x} \\
10^{-13} \mathrm{~s}^{-1}\end{array}$ & 176 \\
\hline & $\begin{array}{c}\text { Bimetallic } \\
\text { combination } \\
\text { with } \mathrm{Cu}\end{array}$ & 438 & 5.2 & 0.63 & Combustion & $\begin{array}{l}\text { Low- } \\
\text { temperature } \\
\text { soot } \\
\text { combustion }\end{array}$ & $\begin{array}{l}5 \% \mathrm{O}_{2} \text { and } \\
95 \% \mathrm{He}, 50 \\
\mathrm{~mL} / \mathrm{min} \text {, mass } \\
\text { ratio(catalyst/ } \\
\text { soot) = 10:1. }\end{array}$ & $\begin{array}{l}\mathrm{T}_{\text {ig }} \& \mathrm{~T}_{\mathrm{f}}= \\
225 \& 410 \\
{ }^{\circ} \mathrm{C}\end{array}$ & 177 \\
\hline \multirow{3}{*}{$\mathrm{Pd} / \mathrm{SBA}-15$} & $\begin{array}{c}\text { In situ } \\
\text { incorporation } \\
\text { within } \\
\text { framework }\end{array}$ & 802 & 5.6 & -- & $\begin{array}{l}\text { Hydrodeoxyge } \\
\text { nation }\end{array}$ & $\begin{array}{l}\text { Hydrodeoxyge } \\
\text { nation } \\
\text { reaction of } \\
\text { phenol }\end{array}$ & $\begin{array}{l}\mathrm{T}=200{ }^{\circ} \mathrm{C} \text { and } \\
\mathrm{P}=30 \text { bar, } \mathrm{t}= \\
1 \mathrm{~h} \\
\text { Phenol }=3 \\
\mathrm{mmol}\end{array}$ & $\begin{array}{l}93 \% \\
\text { product } \\
\text { selectivity }\end{array}$ & 166 \\
\hline & $\begin{array}{l}\text { Promotional } \\
\text { effect of } \mathrm{Mo}_{2} \mathrm{~N}\end{array}$ & 434 & 6.8 & 0.74 & $\begin{array}{l}\text { Hydrogenatio } \\
n\end{array}$ & $\begin{array}{l}\text { Hydrogenatio } \\
\mathrm{n} \text { of } p \text { - } \\
\text { nitrophenol to } \\
p \text { - } \\
\text { aminophenol } \\
\text { using } \mathrm{NaBH}_{4}\end{array}$ & $\begin{array}{l}\text { Catalyst }=10 \\
\mathrm{mg}, \mathrm{T}=25{ }^{\circ} \mathrm{C} \\
\text { and } \mathrm{P}=1 \mathrm{~atm}\end{array}$ & $\begin{array}{l}\text { rate } \\
\text { constant } k \\
=1.33 \mathrm{~min}^{-1}\end{array}$ & 172 \\
\hline & $\begin{array}{c}\text { Bimetallic } \\
\text { combination } \\
\text { with } \mathrm{Au}\end{array}$ & 529 & -- & -- & $\begin{array}{c}\text { Decompositio } \\
\mathrm{n}\end{array}$ & $\begin{array}{l}\mathrm{N}_{2} \mathrm{O} \\
\text { decompositio } \\
\mathrm{n} \text { reaction }\end{array}$ & $\mathrm{T}=400^{\circ} \mathrm{C}$ & $\begin{array}{l}100 \% \\
\text { conversion }\end{array}$ & 174 \\
\hline \multirow{2}{*}{ Pt/SBA-15 } & $\begin{array}{l}-\mathrm{NH}_{2} \text { amine- } \\
\text { functionalized }\end{array}$ & 463 & 6.8 & 0.67 & Reduction & $\begin{array}{l}\text { Catalytic } \\
\text { reduction of } \\
\text { bromate by } \\
\text { hydrogen }\end{array}$ & $\begin{array}{l}\mathrm{T}=25{ }^{\circ} \mathrm{C} \text {, } \\
\text { Initial } \\
\text { concentration } \\
=100 \mathrm{mg} / \mathrm{L}\end{array}$ & $\begin{array}{l}\text { Removal } \\
\text { efficiency = } \\
32.87 \mathrm{mg} \\
\mathrm{min}^{-1} \mathrm{~g}_{\mathrm{cat}}{ }^{-1} \\
\end{array}$ & 167 \\
\hline & $\begin{array}{l}-\mathrm{SO}_{3} \mathrm{H} \text { acid- } \\
\text { functionalized }\end{array}$ & 558 & 4.6 & 0.37 & $\begin{array}{l}\text { Dehydration- } \\
\text { transfer } \\
\text { hydrogenatio } \\
\mathrm{n}\end{array}$ & $\begin{array}{l}\text { Synthesis of } \\
\text { furfuryl } \\
\text { alcohol }\end{array}$ & $\begin{array}{l}T=130^{\circ} \mathrm{C}, \mathrm{t}=6 \\
\mathrm{~h}, \mathrm{P}=30 \mathrm{bar} \\
600 \mathrm{rpm}\end{array}$ & $\begin{array}{l}56 \% \\
\text { conversion } \\
\& 87 \% \\
\text { selectivity } \\
\end{array}$ & 168 \\
\hline \multirow[b]{2}{*}{$\mathrm{Ni} / \mathrm{SBA}-15$} & $\begin{array}{l}\mathrm{TiO}_{2} \text { surface } \\
\text { modification }\end{array}$ & 420 & -- & 0.80 & Oxidation & $\begin{array}{l}\text { Photocatalytic } \\
\text { hydrogen } \\
\text { evolution } \\
\text { from water }\end{array}$ & $\begin{array}{l}\text { Tungsten } \\
\text { electrodes } \\
\text { with ceramic } \\
\text { for plasma } \\
\text { generation }\end{array}$ & $\begin{array}{l}9.39 \mathrm{mmol} \\
\mathrm{h}^{-1} \mathrm{~g}^{-1}\end{array}$ & 171 \\
\hline & $\begin{array}{l}\text { Bimetallic } \\
\text { combination } \\
\text { with Co }\end{array}$ & 261 & 12.0 & -- & Dry reforming & $\begin{array}{l}\text { Dry reforming } \\
\text { of methane }\end{array}$ & $\begin{array}{l}\text { Catalyst }=20 \\
\mathrm{mg}, 40 \mathrm{~mL} \\
\mathrm{~min}^{-1} \mathrm{CH}_{4} \text { and } \\
\mathrm{CO}_{2}(1: 1), \mathrm{T}= \\
750^{\circ} \mathrm{C} \text { for } 42 \\
\text { h. }\end{array}$ & $\begin{array}{l}60 \% \\
\text { methane } \\
\text { conversion }\end{array}$ & 175 \\
\hline $\mathrm{Fe} / \mathrm{SBA}-15$ & $\begin{array}{c}\text { One-pot } \\
\text { hydrothermal } \\
\text { synthesis }\end{array}$ & 517 & 6.67 & -- & $\begin{array}{c}\text { Photocatalytic } \\
\text { degradation }\end{array}$ & $\begin{array}{l}\text { Removal of } \\
\mathrm{Cr}(\mathrm{VI}) \text { and } \\
\text { methylene } \\
\text { blue dye }\end{array}$ & $\begin{array}{l}\text { Visible light } \\
\text { irradiation, } \mathrm{t}= \\
3 \mathrm{~h}\end{array}$ & $\begin{array}{l}\text { photocataly } \\
\text { tic removal } \\
\text { efficiencies } \\
\text { of } 69 \% \mathrm{MB} \\
\text { and } 52 \% \mathrm{Cr} \\
\text { (VI) }\end{array}$ & 173 \\
\hline
\end{tabular}




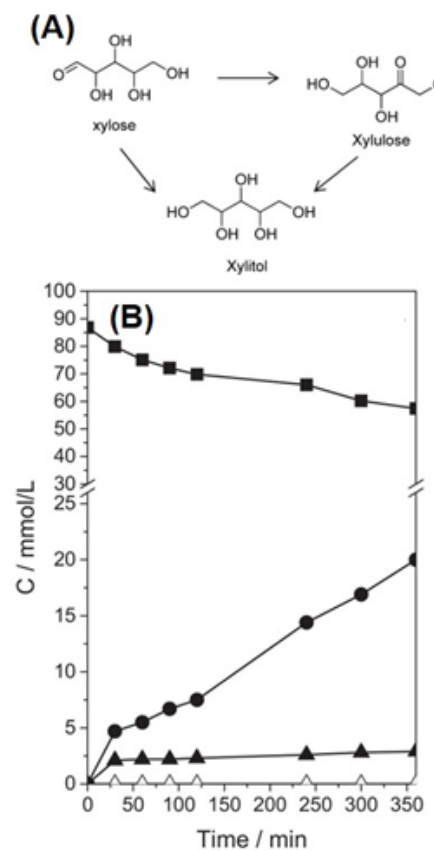

Fig. 8. (A) Reaction pathways of xylose conversion to furfuryl alcohol, (B) Reaction kinetics profile of Pt/SBA-15 and (C) Pt/SBA-15-SO ${ }_{3} \mathrm{H}$. xylose $(\boldsymbol{\bullet})$, xylitol $(\bullet)$, xylulose $(\mathbf{\Delta})$ and furfuryl alcohol $(\Delta)$. Reproduced with permission from ref. [168] Copyright 2017 Elsevier.

Fraga et al. reported the surface modification of SBA-15 by acidic $-\mathrm{SO}_{3} \mathrm{H}$ functional groups to study the aqueous-phase conversion of xylose to furfuryl alcohol. ${ }^{168}$ Furfuryl alcohol is utilized in the synthesis of various chemical resins and intermediates and is usually produced via a 2-step process of xylose dehydration and subsequent furfural hydrogenation. A simplified reaction pathway of xylose conversion to furfuryl alcohol is shown in Fig. 8 (A). In this report, authors have reported the one-pot synthesis of furfuryl alcohol from xylose using Pt NPs supported on acid-functionalized mesoporous silica. $\mathrm{N}_{2}$ physisorption analysis confirmed the preservation of the ordered 2D mesoporous structure after its post-synthetic modifications. Further, the stability of the sulphonyl functional groups was investigated by thermogravimetric measurements coupled with a mass spectrometer (TG-MS). Pt/SBA-15 and $\mathrm{Pt} / \mathrm{SBA}-15-\mathrm{SO}_{3} \mathrm{H}$ displayed xylose conversion of 34 and $65 \%$, respectively, after $6 \mathrm{~h}$ as shown in Fig. 8 (B, C). The obtained selectivity for furfuryl alcohol was found to be $87 \%$ for functionalized catalyst whereas no alcohol was formed when Pt/SBA-15 was used. These catalysts were found to be stable with respect to the ordered mesoporous framework, but acid groups leaching was found to be the major challenge for the pentose valorization process.
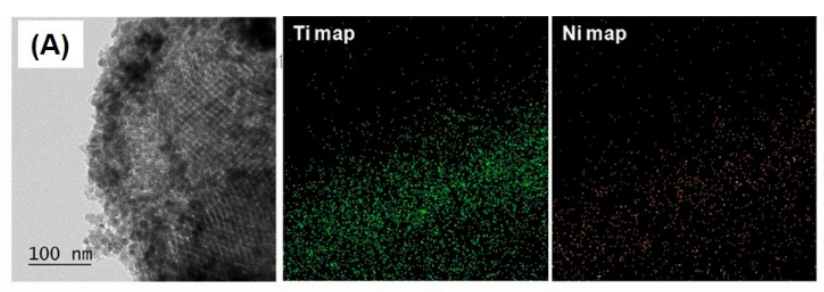

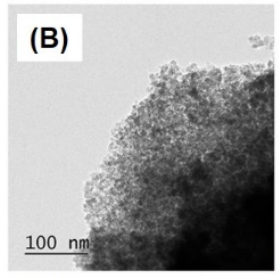

(C)
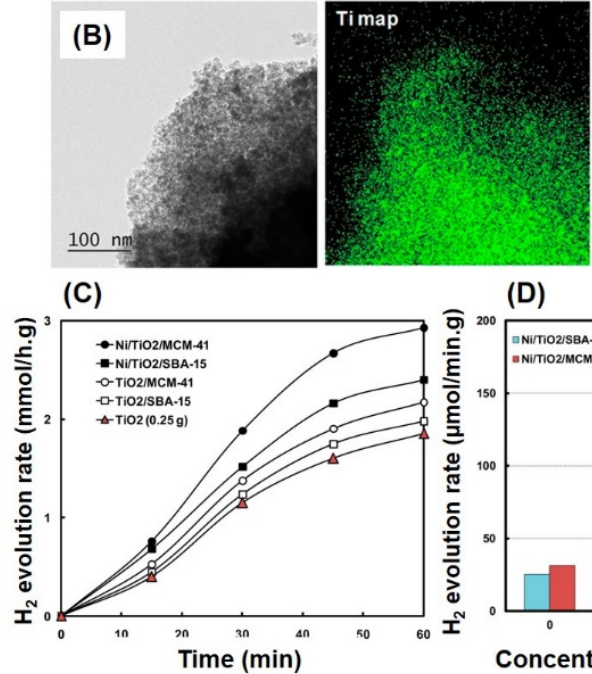

(D)

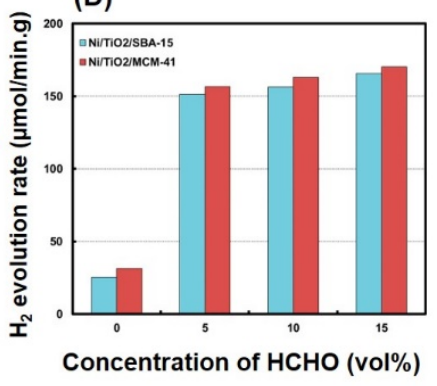

Fig. 9. TEM image and elemental mapping of (A) Ni/TiO $/ 2 / S B A-15$ and (B) $\mathrm{Ni} / \mathrm{TiO}_{2} / \mathrm{MCM}$ 41 (C) Rate of $\mathrm{H}_{2}$ evolution on metal oxide photocatalysts supported on mesoporous materials and (D) dependence of formaldehyde concentration in the hydrogen evolution rate. Reproduced with permission from ref. [171] Copyright 2017 American Chemical Society.

Another study from our group investigated the Ag NPs deposition on $\mathrm{CeO}_{2}$ modified SBA-15 support materials. The $\mathrm{Ag}$ NPs with tunable size and metal-support interactions were prepared by the microwave (MW) irradiation method using 1hexanol as the solvent and reductant. ${ }^{169,170}$ The NPs size increased from $1.9 \mathrm{~nm}$ to $3.9 \mathrm{~nm}$ on changing the different loading amounts of $\mathrm{CeO}_{2}$ from 0.5 to $2.0 \mathrm{wt} \%$ on SBA-15. In this study, the effects of particle size and metal support interactions were investigated by two model reactions namely ammonia borane (AB) dehydrogenation and 4-nitrophenol (NP) reduction. The catalytic activity results revealed that $\mathrm{Ag} / \mathrm{CeO}_{2}-$ SBA-15 catalyst prepared by MW displayed higher TOF values than those of $\mathrm{Ag} / \mathrm{SBA}-15$ and $\mathrm{Ag} / \mathrm{CeO}_{2}-\mathrm{SBA}-15$ prepared by the conventional oil-bath heating method. The high TOF values for the hydrogen production from $A B$ dehydrogenation $\left(0.41 \mathrm{~min}^{-1}\right)$ was attributed to the size of Ag NPs and both NPs size and metal-support interactions were explained for the reduction of 4-NP $\left(555 \mathrm{~min}^{-1}\right)$. The difference in the catalytic activity was explained due to the surface electronic structure of Ag NPs. The interaction of $\mathrm{Ag}$ with the $\mathrm{O}$ atoms of $\mathrm{CeO}_{2}$ assists in the easy adsorption of substrate molecules, leading to the higher TOF values in the catalytic reaction.

$\mathrm{S}-\mathrm{C}$. Jung et al. explored the surface modification of SBA-15 and MCM-41 by $\mathrm{TiO}_{2}$ followed by NPs deposition. ${ }^{171}$ The use of 
mesoporous materials provides support for fixation of higher loadings of $\mathrm{TiO}_{2}$ (above $50 \mathrm{wt} \%$ ) on its surface because of their large pore size and wide surface area values. After postmodification, the specific surface area and pore volume values were reduced significantly. Specifically, the pore volume of $\mathrm{TiO}_{2} / \mathrm{SBA}-15$ reduced by $37.5 \%$, indicating the pore occupancy of SBA-15 by $\mathrm{TiO}_{2}$ particles. In contrast, $\mathrm{MCM}-41$ has $\mathrm{TiO}_{2}$ particles mainly loaded on the surface because of its smaller pore size and higher exposed elements on its surface as investigated by TEM-EDS analysis. The amount of $\mathrm{TiO}_{2}$ content was higher on MCM-41 (58.4 wt \%) than SBA-15 (43.6 wt \%). This report utilizes supported Ni NPs for the challenging photocatalytic hydrogen evolution from water reaction. Fig. 9 (A, B) displays the TEM images and elemental mapping of prepared $\mathrm{Ni} / \mathrm{TiO}_{2} / \mathrm{SBA}-15$ and $\mathrm{Ni} / \mathrm{TiO}_{2} / \mathrm{MCM}-41$, suggesting the successful incorporation of Ni NPs without aggregation on $\mathrm{TiO}_{2}$ supported on mesoporous materials. The water splitting reaction is significant for exploiting the solar energy and converting into clean and renewable hydrogen energy. Liquid phase plasma irradiation has been used to generate hydrogen from the photodecomposition of water. Very few reports outline plasma reforming in liquid phase, because it is performed in gas phase for water treatment applications. Liquid phase plasma (LPP) reforming generates relatively high-density plasma which can be employed for decomposition of water into hydrogen. The hydrogen evolution by LPP was found to be the highest for $\mathrm{Ni} / \mathrm{TiO}_{2}$ photocatalyst as $\sim 2.2 \mathrm{mmol} \mathrm{h}^{-1} \mathrm{~g}^{-1}$ and it was further enhanced when mesoporous silica was used as the support material as shown in Fig. $\mathbf{9}$ (C). They also investigated the addition of formaldehyde as the additional source of hydrogen and sacrificial agent to increase the overall rate of hydrogen evolution. $\mathrm{Ni} / \mathrm{TiO}_{2} / \mathrm{MCM}-41$ photocatalysts displayed superior catalytic performance of $9.39 \mathrm{mmol} \mathrm{h}^{-1} \mathrm{~g}^{-1}$ with the addition of 5 vol\% formaldehyde solution in the reaction mixture. Similar results were observed with SBA-15 as the mesoporous support material as shown in Fig. 9 (D).

Another interesting research focused on exploiting the porous interconnected network of mesoporous silica to prepare highly efficient catalysts. This article is based on creating low loadings of Pd on SBA-15 by the promotional effect of ultra-small (2-3 $\mathrm{nm}) \mathrm{Mo}_{2} \mathrm{~N}$ particles anchored on silica. ${ }^{172}$ The small-sized $\mathrm{Mo}_{2} \mathrm{~N}$ was loaded by using $\mathrm{PMo}_{12}$ clusters (12-phosphomolybdic acid, $\mathrm{H}_{3} \mathrm{PMo}_{12} \mathrm{O}_{40}$ ) as the precursor to modify the surface of functionalized $\mathrm{NH}_{2}$-SBA-15. Subsequently, 1 wt \% of Pd NPs were loaded on $\mathrm{Mo}_{2} \mathrm{~N} / \mathrm{SBA}-15$ by reducing the precursor $\mathrm{PdCl}_{2}$ with $\mathrm{NaBH}_{4}$ aqueous solution. The structural resemblance of $\mathrm{Mo}_{2} \mathrm{~N}$ with noble metal allows the $\mathrm{Pd}$ to grow epitaxially to form Pd-Mo heterojunctions. The transfer of electrons between Mo and $\mathrm{Pd}$ and hence the heterojunction was confirmed by XPS by studying the shift in the binding energy values. The effect of $\mathrm{Mo}_{2} \mathrm{~N}$ as a co-catalyst for $\mathrm{Pd} N \mathrm{Ns}$ was tested in the hydrogenation of $p$-nitrophenol to $p$-aminophenol in the presence of $\mathrm{NaBH}_{4}$ as the hydrogen source. The rate constant $k$ of $\mathrm{Pd}(1 \mathrm{wt} \%)-\mathrm{Mo}_{2} \mathrm{~N} / \mathrm{SBA}-15$ was observed to be $1.33 \mathrm{~min}^{-1}$, which was higher than $1.09 \mathrm{~min}^{-1}$ on $\mathrm{Pd}(20$ wt \%)/SBA-15 and $0.005 \mathrm{~min}^{-1}$ on $\mathrm{Pd}(1 \mathrm{wt} \%) / \mathrm{SBA}-15$. These results describe the synergistic effect of $\mathrm{Pd}-\mathrm{Mo}$ to boost the rate of catalytic reaction. This report can be cited as a remarkable example of implementing support with a larger number of pores which not only assists in the uniform dispersion of metal species but also
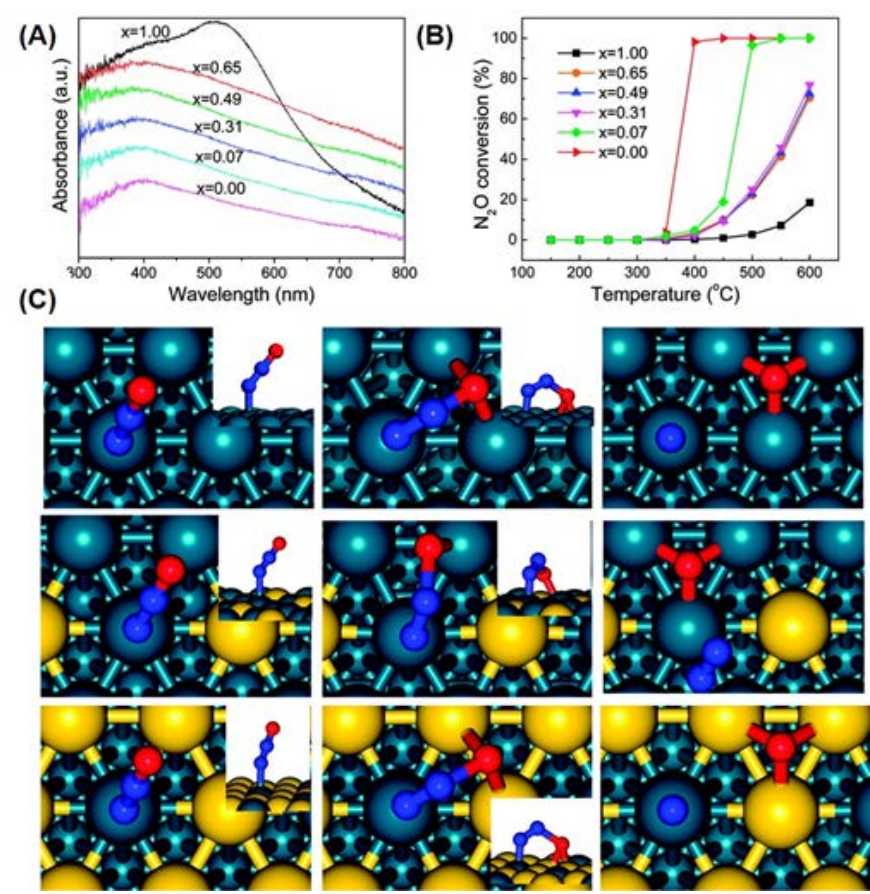

Fig. 10. (A) UV-vis spectra of $\mathrm{Au}_{x} \mathrm{Pd}_{1-x} / \mathrm{SBA}-15$ catalysts (B) Catalytic performance of $\mathrm{N}_{2} \mathrm{O}$ conversion vs reaction temperature over $\mathrm{Au}_{x} \mathrm{Pd}_{1-x} / \mathrm{SBA} 15$ catalysts and (C) Geometric structures of $\mathrm{N}_{2} \mathrm{O}$ adsorption and decomposition into $\mathrm{N}_{2}+\mathrm{O}_{\text {ad }}$ over $\mathrm{Pd}(111), \mathrm{Pd}_{3} \mathrm{Au} / \mathrm{Pd}$ (111) and $\mathrm{PdAu}_{3} / \mathrm{Pd}$ (111) surfaces. Reproduced with permission from ref. [174] Copyright 2012 American Chemical Society.

helps in the mass transport and diffusion of reactant and product molecules. Saad et $a l$. also explored the same reaction by employing triazole/triazine-functionalized Pd/SBA-15 catalyst with a reaction rate constant for $p$-nitrophenol reduction of $16.8 \times 10^{-3} \mathrm{~s}^{-1}$. $^{158}$

$\mathrm{Hu}$ et al. explored the $\mathrm{Fe}-\mathrm{TiO}_{2}$ deposition on silica support ( $\left.\mathrm{Fe}-\mathrm{TiO}_{2}-\mathrm{SBA}-15, \mathrm{FTS}\right)$ via a one-pot hydrothermal synthesis route. ${ }^{173}$ Literature survey revealed that Fe ions can replace the $\mathrm{Ti}^{4+}$ species from its lattice structure and create a new energy level in the bandgap of $\mathrm{TiO}_{2}$ for enhanced visible light absorbance. Bare $\mathrm{TiO}_{2}$ suffers aggregation of particles and hence can't be employed for efficient photocatalytic reactions. The fabrication of $\mathrm{TiO}_{2}$ particles on mesoporous silica leads to enhanced stability and control growth with relatively larger surface area values. The FTS samples contained mixed ratios of anatase and rutile $\mathrm{TiO}_{2}$ with a 2D hexagonal network of mesoporous silica. XRD peaks indexing to (100), (110) and (200) confirms the 2-D structure with $p 6 \mathrm{~mm}$ symmetry. Apart from the characteristic absorption of $\mathrm{TiO}_{2}$ in the UV regime, a small peak at $500 \mathrm{~nm}$ was observed in the UV-vis spectra due to the $d$-d transition of Fe species, ${ }^{2} T_{2 g} \rightarrow{ }^{2} A_{2 g}$. SEM indicated capsulelike morphology of SBA-15 and doping with $\mathrm{Ti}$ and Fe leads to roughening of the surface, preserving the ordered structure as confirmed by TEM and $\mathrm{N}_{2}$ physisorption. The removal of $\mathrm{Cr}(\mathrm{VI})$ and methylene blue (MB) dye was investigated using FTS (Fe/Si 
$=0.03$ ) based catalysts. An aqueous suspension containing both $\mathrm{MB}$ and $\mathrm{Cr}$ exhibited photocatalytic removal efficiencies of $69 \%$ $\mathrm{MB}$ and $52 \% \mathrm{Cr}(\mathrm{VI})$ which were much higher than these contaminants were tested individually. This was attributed to the simultaneous consumption of photogenerated electron and holes for oxidizing and reducing the contaminants. Further, the authors have proposed a creation of a new energy level in the $\mathrm{CB}$ and $\mathrm{VB}$ of $\mathrm{TiO}_{2}$, which assists in the separation of charge carriers. Chehimi's group reported the Ag/AMT-SBA-15 and Ag/Tr-SBA-15 where AMT and Tr represents 2-aminothiazole and aminopropyl-triazole groups, respectively for the reduction of methylene blue. ${ }^{157}$ Superior catalytic performance of $\mathrm{Ag} / \mathrm{Tr}$ SBA-15 was obtained with rate constants of $14.3 \times 10^{-3} \mathrm{~s}^{-1}$.

Li's group reported that highly dispersed Au-Pd bimetallic alloy NPs were prepared by the adsorption-reduction method on amine-functionalized SBA-15 support. ${ }^{174}$ Different atomic ratios of $\mathrm{Au}_{\mathrm{x}} \mathrm{Pd}_{1-\mathrm{x}} / \mathrm{SBA}-15$ were prepared with the total metal loading to be fixed at $2 \mathrm{wt} \%$ and an average NPs size ranging from 1.7-2.4 $\mathrm{nm}$ was observed. The absence of an absorption band in bimetallic catalysts confirms the presence of singlephase characteristics of bimetallic alloy catalysts as shown in Fig. 10 (A). The prepared catalysts were tested in the $\mathrm{N}_{2} \mathrm{O}$ decomposition reaction. The rate-determining step for $\mathrm{N}_{2} \mathrm{O}$ decomposition reaction is the desorption of oxygen adatoms and hence chemisorption studies were carried out by using AuPd/SBA-15 catalysts. Authors have observed that the $\mathrm{N}_{2} \mathrm{O}$ decomposition activity decreased on increasing the $\mathrm{Au} \%$ in the Au-Pd alloy catalysts in comparison to bare Pd/SBA-15 catalyst as summarized in Fig. 10 (B). DFT calculations were performed to investigate the mechanism for this reaction. Fig. 10 (C) shows the geometric structures of $\mathrm{N}_{2} \mathrm{O}$ adsorption and decomposition into $\mathrm{N}_{2}$ and $\mathrm{O}_{\text {ads }}$ over Pd and Au-Pd catalysts as determined by DFT calculations. The calculations indicated that the $\mathrm{Au}$ incorporation assists in the desorption of $\mathrm{O}_{2}$ but $\mathrm{Pd}$ acts as the active sites for the elementary step decomposition of $\mathrm{N}_{2} \mathrm{O}$ to $\mathrm{N}_{2}$ and oxygen adatoms. Therefore Au-Pd catalysts have a higher energy barrier than in Pd catalysts, leading to lower catalytic activities for the decomposition reaction.

Caballero's group has recently addressed the process of dry reforming of methane using $\mathrm{Ni}$ and $\mathrm{Co}$ metal NPs deposited on SBA-15 catalysts at $750{ }^{\circ} \mathrm{C}$ for $42 \mathrm{~h} .{ }^{175}$ The reaction is of interest because it utilizes two of the harmful greenhouse gases, methane and $\mathrm{CO}_{2}$ and transforms them into hydrogen and carbon monoxide as shown in equation $1 .{ }^{156}$ Steam reforming of methane, which utilizes methane and water converts them into hydrogen and $\mathrm{CO}$ is also shown in equation 2.

Dry reforming of methane (DRM)

$$
\mathrm{CH}_{4}+\mathrm{CO}_{2} \rightarrow 2 \mathrm{H}_{2}+2 \mathrm{CO}
$$

Steam reforming of methane (SRM)

$$
\mathrm{CH}_{4}+\mathrm{H}_{2} \mathrm{O} \rightarrow 3 \mathrm{H}_{2}+\mathrm{CO}
$$

The catalysts, $\mathrm{Ni} / \mathrm{SBA}-15, \mathrm{Ni}-\mathrm{Co} / \mathrm{SBA}-15$ and $\mathrm{Co} / \mathrm{SBA}-15$ were studied and the catalytic performances were completely dependent on the type of metal used for the dry reforming reaction. Ni/SBA-15 displayed superior catalytic performance in the $60 \%$ methane conversion during $48 \mathrm{~h}$ of DRM reaction whereas Co/SBA-15 found to be completely inactive for this reaction. The bimetallic NiCo/SBA-15 catalyst displayed dual behavior with an initial methane conversion of $35 \%$ but loses its activity completely after $5 \mathrm{~h}$ of reaction time. The monometallic NPs maintain its size and distribution after the reaction, also justifying their stable catalytic performances. The bimetallic NPs as evidenced by the TEM images increased their NPs size from 6 to $8 \mathrm{~nm}$ after the reaction. The difference in the NPs size before and after the reaction was correlated to the interaction between metal NPs and SBA-15 support material. Monometallic NPs maintain strong metal-support interaction and hence maintain their size even after the reaction, unlike the bimetallic NPs. Erdogan et al. reported high conversion of $73 \%$ methane and $89 \% \mathrm{CO}_{2}$ at $750{ }^{\circ} \mathrm{C}$ using $\mathrm{Ni}-\mathrm{Co} / \mathrm{SBA}-15$ catalysts $(\mathrm{Ni}: \mathrm{Co}=4){ }^{156}$

Jongh et al. have recently utilized the SBA-15 support material to deposit nanosized Ag-Au bimetallic NPs to investigate the selective hydrogenation of butadiene. ${ }^{176}$ The size of the monometallic and bimetallic NPs was found to be 2$4 \mathrm{~nm}$ which were deposited within the $8 \mathrm{~nm}$ wide mesopores of silica. The absorption maximum peak of Au/SBA-15, Ag/SBA-15, Au3Ag1/SBA-15 and Au2Ag1/SBA-15 catalysts was observed at 390,510 and 500 and $485 \mathrm{~nm}$ which are characteristic of surface plasmon resonance. These catalysts were then tested in the hydrogenation of butadiene at temperatures from 50 to $300{ }^{\circ} \mathrm{C}$. The main products obtained were 1-butene, cis-2-butene and trans-2-butene in the order of decreasing concentrations. The presence of butane was found to be below the detection limit for all the catalysts. The bimetallic ( $\mathrm{Au}-\mathrm{Ag}$ ) and $\mathrm{Au}$ catalyst displayed higher selectivity, whereas Ag had no effect on the selectivity of the reaction. The TOF value of $5.6 \times 10^{-13} \mathrm{~s}^{-1}$ calculated at $120^{\circ} \mathrm{C}$ was found to be highest for Au2Ag1/SBA15 catalyst followed by $5.4 \times 10^{-13} \mathrm{~s}^{-1}$ and $4.4 \times 10^{-13} \mathrm{~s}^{-1}$ for Au3Ag1/SBA-15 and Au/SBA-15 catalysts, respectively. Ag/SBA15 displayed negligible conversion of the substrate at similar temperature conditions. The slow reaction rates for $\mathrm{Ag}$ catalysts, despite lower activation barrier, was attributed to the lower concentration of butadiene molecules adsorbing on the surface of Ag NPs.

Another interesting study employing the use of SBA-15 as the support material was published by Yuan et al. for investigating the low-temperature soot combustion performance of Ag-Cu NPs deposited on SBA-15. ${ }^{177}$ The size of bimetallic $\mathrm{Ag}-\mathrm{Cu}$ alloy NPs was observed to be $2.6 \mathrm{~nm}$ which was smaller than the size of monometallic Ag/SBA-15 (3.7 nm) catalyst. The $\mathrm{Cu}$ addition in the $\mathrm{Ag}$ catalysts displayed synergistic catalysis of soot combustion by increasing the active oxygen species on the surface of NPs. Blank mesoporous silica was found to combust the soot at $\mathrm{T}_{\text {ig }}$ and $\mathrm{T}_{f}$ of $500^{\circ} \mathrm{C}$ and $660^{\circ} \mathrm{C}$, respectively, which were lower than those of soot alone $\left(\mathrm{T}_{\mathrm{ig}}=\right.$ $535^{\circ} \mathrm{C}, \mathrm{T}_{\mathrm{f}}=695^{\circ} \mathrm{C}$ ), evidencing the significance of easy-diffusion induced by SBA-15. As expected, lower combustion temperatures were obtained for the mono and bimetallic catalysts. Amongst different ratios of Ag-Cu catalysts prepared, the superior catalytic performance was shown by $5 \mathrm{wt} \%$ of $\mathrm{Ag}_{1^{-}}$ $\mathrm{Cu}_{0.1} / \mathrm{SBA}-15$ ( 1 and 0.1 are the atomic ratios of $\mathrm{Ag}$ and $\mathrm{Cu}$ ) at $\mathrm{T}_{\mathrm{ig}}$ and $T_{f}$ of 225 and $410{ }^{\circ} \mathrm{C}$ respectively. The observed synergistic catalytic performance of $\mathrm{Ag}$ and $\mathrm{Cu}$ was explained by a charge transfer promotion between $\mathrm{Cu}$ and $\mathrm{Ag}$ which favors $\mathrm{O}_{2}$ 
adsorption on the surface of the NPs. The higher density of active oxygen species was concluded to be the main factor in displaying superior catalytic performances of bimetallic NPs.

\subsection{Immobilization of metal oxides within the pore channels}

This section describes the recent advancements of different metal oxide functionalized SBA-15 catalysts explored in different catalytic reactions, also summarized in Table 5. ${ }^{178-180}$ For example; recent research from our group investigated $\mathrm{ZrO}_{2}$ species deposition on silica for the catalytic conversion reaction of levulinic acid (LA) and its esters to $\gamma$-Valerolactone (GVL). ${ }^{181,182} \mathrm{GVL}$, a precursor producing various industrially valuable chemicals like olefins, fuel-additive, polymers and other value-added chemicals, is synthesized from biomassderived LA and its esters utilizing alcohol as the $\mathrm{H}$-donor via catalytic transfer hydrogenation (CTH) process. The catalyst was synthesized by the in-situ hydrolysis of zirconium $n$-butoxide $\left(\mathrm{Zr}\left(\mathrm{O}^{n} \mathrm{Bu}\right)_{4}\right), 70 \%$ in $n$-butanol) on oxide support in an organic solvent. It was observed that supported $\mathrm{ZrO}_{2}$ catalysts displayed superior catalytic performances than the bulk $\mathrm{ZrO}_{2}$ using the same reaction conditions. $10 \mathrm{wt} \%$ of $\mathrm{ZrO}_{2}$ on SBA-15 afforded a superior yield of $88 \% \mathrm{GVL}$ and $98 \%$ conversion at $150{ }^{\circ} \mathrm{C}$ for 2 h. From XAFS analysis as shown in Fig. 11 (A), it was revealed that the highly dispersed $\mathrm{Zr}^{4+}$ species of low coordination number ( $\mathrm{C} . \mathrm{N} .=4.5)$ with reduced $\mathrm{Zr}-\mathrm{O}$ distance $(\mathrm{R}=2.12 \AA$ ) on silica surface are the dominant species for this reaction and high surface area silica assist in providing the suitable environment for generating such active species. In contrast, the bulk $\mathrm{ZrO}_{2}$ and silica with higher loading levels of $\mathrm{ZrO}_{2}$ displayed C.N. of 7.1 and $\mathrm{Zr}-\mathrm{O}$ distance of $2.16 \AA$ and thus indicating the formation of aggregated $\mathrm{ZrO}_{2}$ species. A plot of catalytic activities against the C.N. of Zr atoms is shown in Fig. 11 (B). Further in-situ FTIR and
TPD measurement analysis were employed to propose the reaction mechanistic pathway. The supported catalyst was found to be stable and reusable for up to 5 catalytic cycles, whereas the bulk $\mathrm{ZrO}_{2}$ lost most of its activity in the same number of catalytic cycles. The loss of activity was attributed to the strong adsorption of residue species on the surface of catalyst inhibiting the access of new substrate molecules to the active $\mathrm{Zr}$ species.

Another study addresses the CaP coating on $\mathrm{TiO}_{2} / \mathrm{SBA}-15$ composite which was prepared by a sol-gel process and used as a photocatalyst for methylene blue dye degradation. ${ }^{183}$ An illustrative scheme of the preparation of $\mathrm{CaP}$ coated $\mathrm{TiO}_{2} / \mathrm{SBA}$ 15 has been presented in Fig. 12 (A). CaP coating displayed positive results in enhancing the pore occupancy and efficient degradation of the dye molecules than the pristine $\mathrm{TiO}_{2} / \mathrm{SBA}$ 15. A series of catalysts were reported by tuning the mass ratios of $\mathrm{Ca}$ and $\mathrm{P}$ in the photocatalyst varying from 4.6 to $18.7 \mathrm{wt} \%$. The $\mathrm{N}_{2}$ physisorption analysis results confirmed the type IV curve characteristic of highly ordered mesoporous structure even after $\mathrm{CaP}$ incorporation. The coating of $\mathrm{CaP}$ enhances the pore occupancy for MB dye molecules, implying the affinity of the CaP phase for the dye molecules. A time-dependent degradation efficiency (Fig. 12 (B)) and removal efficiency arising from adsorption, degradation and sum of both (total) for $\mathrm{TiO}_{2} / \mathrm{SBA}-15, \mathrm{CaP}_{\mathrm{x}} @ \mathrm{TiO}_{2} / \mathrm{SBA}-15(\mathrm{x}=4.6,9.4$ and 18.7$)$ and mixture of hydroxyapatite $\left(\mathrm{Ca}_{10}\left(\mathrm{PO}_{4}\right)_{6}(\mathrm{OH})_{2}\right.$, HAp) with $\mathrm{TiO}_{2} / \mathrm{SBA}-15$, is shown in Fig. 12 (C). Under UV-light irradiation, the dye degradation efficiency was significantly enhanced due to the higher pore occupancy and uniform combination of adsorption site (CaP) and degradation site $\left(\mathrm{TiO}_{2}\right)$ in the photocatalyst.

Table 5. Catalytic systems with metal oxides deposited mesoporous silica, SBA-15

\begin{tabular}{|c|c|c|c|c|c|c|c|c|c|}
\hline \multirow[b]{2}{*}{$\begin{array}{l}\text { Descriptor } \\
\text { (Metal } \\
\text { Oxides) }\end{array}$} & \multirow[b]{2}{*}{$\begin{array}{c}\text { Sub- } \\
\text { descriptor }\end{array}$} & \multicolumn{3}{|c|}{ Physicochemical properties } & \multirow[b]{2}{*}{ Reaction Type } & \multirow[b]{2}{*}{$\begin{array}{l}\text { Catalytic } \\
\text { reaction }\end{array}$} & \multirow[b]{2}{*}{$\begin{array}{l}\text { Reaction } \\
\text { conditions }\end{array}$} & \multirow[b]{2}{*}{$\begin{array}{c}\text { Catalytic } \\
\text { performanc } \\
\text { e }\end{array}$} & \multirow[b]{2}{*}{ Ref. } \\
\hline & & $\begin{array}{l}\text { Surfac } \\
\text { e area } \\
\left(\mathrm{m}^{2} / \mathrm{g}\right) \\
\end{array}$ & $\begin{array}{l}\text { Pore } \\
\text { size } \\
(\mathrm{nm}) \\
\end{array}$ & $\begin{array}{c}\text { Pore } \\
\text { volume } \\
\left(\mathrm{cm}^{3} / \mathrm{g}\right)\end{array}$ & & & & & \\
\hline $\begin{array}{c}\mathrm{ZrO}_{2} / \mathrm{SBA}- \\
15\end{array}$ & $\begin{array}{l}\text { Synthesis } \\
\text { by in-situ } \\
\text { hydrolysis }\end{array}$ & 810 & 7.7 & 1.03 & $\begin{array}{l}\text { Catalytic } \\
\text { transfer } \\
\text { hydrogenatio } \\
\mathrm{n}\end{array}$ & $\begin{array}{l}\text { Synthesis of } y^{-} \\
\text {Valerolactone } \\
(\mathrm{GVL})\end{array}$ & $\begin{array}{l}\text { Catalyst: } 40 \mathrm{mg}, \\
\text { 2-PrOH }=10 \mathrm{~mL}, \\
\mathrm{~T}=150^{\circ} \mathrm{Ct}=3 \mathrm{~h}\end{array}$ & $\begin{array}{l}91 \% \text { GVL } \\
\text { yield \& } 99.5 \\
\% \\
\text { conversion }\end{array}$ & $\begin{array}{l}181, \\
182\end{array}$ \\
\hline \multirow{2}{*}{$\begin{array}{c}\mathrm{TiO}_{2} / \mathrm{SBA}- \\
15\end{array}$} & $\begin{array}{l}\text { CaP coating } \\
\text { by sol-gel } \\
\text { process }\end{array}$ & 434 & 7.0 & 0.59 & $\begin{array}{l}\text { Photocatalytic } \\
\text { degradation }\end{array}$ & $\begin{array}{l}\text { Photocatalytic } \\
\text { degradation } \\
\text { of methylene } \\
\text { blue dye }\end{array}$ & $\begin{array}{l}\text { Catalyst: } 20 \mathrm{mg} \text {, } \\
\text { UV-light } \\
\text { irradiation }(\lambda=360 \\
\left.\mathrm{nm}, 5 \mathrm{~mW} / \mathrm{cm}^{2}\right)\end{array}$ & $\begin{array}{l}\text { Dye } \\
\text { degradation } \\
\text { efficiency = } \\
45 \%\end{array}$ & 183 \\
\hline & $\begin{array}{l}\text { Monometal } \\
\text { lic Au } \\
\text { incorporati } \\
\text { on }\end{array}$ & 431 & -- & -- & Oxidation & $\begin{array}{l}\text { Low- } \\
\text { temperature } \\
\text { CO oxidation } \\
\text { reaction }\end{array}$ & $\begin{array}{l}\mathrm{T}=\quad 180 \quad{ }^{\circ} \mathrm{C}, \\
\text { catalyst: } 65 \mathrm{mg} \text {, } \\
\text { gas flow rate }=60 \\
\mathrm{~mL} / \mathrm{min}\end{array}$ & $\begin{array}{l}\text { initial rate } \\
10.4 \times 10^{3} \\
\mathrm{~mol}^{-1} \mathrm{~g}^{-1} \mathrm{~s}^{-1}\end{array}$ & 187 \\
\hline \multirow{2}{*}{$\begin{array}{c}\mathrm{CuO} / \mathrm{SBA}- \\
15\end{array}$} & $\begin{array}{l}\text { Size- } \\
\text { controlled } \\
\text { particles }\end{array}$ & 433 & 7.9 & -- & Oxidation & $\begin{array}{ll}\begin{array}{l}\text { Oxidation of } \\
\text { propene }\end{array} & \text { to } \\
\text { propylene } & \\
\text { oxide } & \\
\end{array}$ & $\begin{array}{l}5 \% \text { propene and } 5 \\
\% \text { oxygen } \\
\text { balanced by } \mathrm{He} \text {, } \\
\mathrm{T}=350^{\circ} \mathrm{C}, \mathrm{t}=12 \mathrm{~h}\end{array}$ & $\begin{array}{l}2.7 \quad \% \\
\text { selectivity of } \\
\text { PO }\end{array}$ & 184 \\
\hline & $\begin{array}{l}\text { Wet } \\
\text { impregnati } \\
\text { on method }\end{array}$ & 508 & -- & 0.45 & $\begin{array}{c}\text { Partial } \\
\text { oxidation }\end{array}$ & $\begin{array}{l}\text { Conversion of } \\
\text { methane to } \\
\text { methanol }\end{array}$ & $\mathrm{T}=200^{\circ} \mathrm{C}, \mathrm{t}=3 \mathrm{~h}$ & $\begin{array}{l}30.2 \mu \mathrm{molg}^{-1} \\
\text { yield of } \\
\text { methanol }\end{array}$ & 185 \\
\hline
\end{tabular}




\begin{tabular}{|c|c|c|c|c|c|c|c|c|c|}
\hline & $\begin{array}{l}\text { of } \\
\text { synthesis }\end{array}$ & & & & & & & & \\
\hline & $\begin{array}{l}\text { Bimetallic } \\
\text { combinatio } \\
n \text { with NiO }\end{array}$ & 389 & 6.59 & 0.57 & Epoxidation & $\begin{array}{l}\text { Epoxidation of } \\
\text { styrene using } \\
\text { TBHP as } \\
\text { oxidant }\end{array}$ & $\begin{array}{l}\text { Catalyst= } 0.0129 \\
\mathrm{mmol} \mathrm{CuO}, \quad 3 \\
\mathrm{mmol} \text { styrene, } 5 \\
\mathrm{mmol} \quad \mathrm{TBHP}, \\
\mathrm{CH}_{3} \mathrm{CN}=5 \mathrm{~mL}, \mathrm{~T}= \\
80{ }^{\circ} \mathrm{C}, \mathrm{t}=6 \mathrm{~h}, \\
\text { nitrobenzene as } \\
\text { the internal } \\
\text { standard }\end{array}$ & $\begin{array}{l}100 \quad \% \\
\text { conversion } \\
\text { and } 92 \% \\
\text { selectivity of } \\
\text { epoxide }\end{array}$ & 192 \\
\hline & $\begin{array}{l}\text { Bimetallic } \\
\text { combinatio } \\
\mathrm{n} \text { with } \mathrm{ZnO}\end{array}$ & 676 & 5.7 & 0.7 & $\begin{array}{c}\text { Hydrogenatio } \\
n\end{array}$ & $\begin{array}{l}\text { Synthesis of } \\
\text { methanol }\end{array}$ & $\begin{array}{l}\text { Catalyst }=50 \mathrm{mg}, \\
\mathrm{T}=220^{\circ} \mathrm{C}, 72 \% \mathrm{H}_{2}, \\
10 \% \\
\mathrm{CO}, 4 \% \mathrm{CO}_{2} \text { in } \mathrm{He}, \\
\mathrm{P}=8 \text { bar }\end{array}$ & $\begin{array}{l}\text { reaction } \\
\text { rate }=1.90 \\
\mu \mathrm{molh}^{-1} \mathrm{~g}^{-1}\end{array}$ & 193 \\
\hline $\begin{array}{c}\mathrm{WO}_{3} / \mathrm{SBA}- \\
15\end{array}$ & $\begin{array}{l}\text { Wet } \\
\text { impregnati } \\
\text { on method } \\
\text { of synthesis }\end{array}$ & 498 & 6.31 & 0.86 & Oxidation & $\begin{array}{l}\text { Oxidative } \\
\text { removal of } \\
4,6- \\
\text { dimethyldibe } \\
\text { nzothiophene } \\
\text { (DMDBT) }\end{array}$ & $\begin{array}{l}\text { Catalyst }=30 \mathrm{mg}, \\
\mathrm{T}=60^{\circ} \mathrm{C},[4,6 \\
\text { DBDBT }]=300 \mathrm{ppm}\end{array}$ & $\begin{array}{l}99 \% \\
\text { removal } \\
\text { efficiency }\end{array}$ & 186 \\
\hline $\begin{array}{c}\mathrm{NbO} / \mathrm{SBA}- \\
15\end{array}$ & $\begin{array}{l}\text { Coordinati } \\
\text { on } \\
\text { geometry } \\
\text { and Lewis } \\
\text { acidity }\end{array}$ & 733 & -- & -- & Esterification & $\begin{array}{l}\text { Biodiesel } \\
\text { production }\end{array}$ & $\begin{array}{c}\text { Catalyst }=50 \mathrm{mg}, \\
\mathrm{T}=60^{\circ} \mathrm{C}, 10 \mathrm{mmol} \\
\text { of propionic acid }\end{array}$ & $\begin{array}{c}16 \% \\
\text { conversion }\end{array}$ & 188 \\
\hline $\begin{array}{c}\mathrm{FeO}_{x} / \mathrm{SBA}- \\
15\end{array}$ & $\begin{array}{l}\text { Structural } \\
\text { symmetry }\end{array}$ & 601 & 5.7 & 0.75 & Oxidation & $\begin{array}{l}\text { Selective } \\
\text { oxidation of } \\
\mathrm{CH}_{4} \text { to } \mathrm{HCHO}\end{array}$ & $\begin{array}{l}\text { Catalyst }=200 \mathrm{mg}, \\
\mathrm{T}=625^{\circ} \mathrm{C}, \mathrm{P}\left(\mathrm{CH}_{4}\right) \\
=\mathrm{P}\left(\mathrm{O}_{2}\right)=33.8 \mathrm{kPa}\end{array}$ & $\begin{array}{l}5.0 \% \\
\text { conversion } \\
\text { and } 1.9 \% \\
\mathrm{HCHO} \text { yield }\end{array}$ & 194 \\
\hline \multirow[b]{2}{*}{$\begin{array}{c}\mathrm{MnO}_{\mathrm{x}} / \mathrm{SBA}- \\
15\end{array}$} & $\begin{array}{l}\mathrm{Pd} \quad \mathrm{NPs} \\
\text { deposition }\end{array}$ & 289 & 9.3 & 0.68 & $\begin{array}{l}\text { Dehydrogenat } \\
\text { ion }\end{array}$ & $\begin{array}{c}\text { Formic acid } \\
\text { (HCOOH) } \\
\text { dehydrogenat } \\
\text { ion } \\
\end{array}$ & $\begin{array}{l}\text { Catalyst }=55 \mathrm{mg}, \\
\mathrm{T}=25^{\circ} \mathrm{C}, \mathrm{HCOOH}= \\
0.19 \mathrm{~mL}, \quad \mathrm{H}_{2} \mathrm{O}= \\
10 \mathrm{~mL}\end{array}$ & $\begin{array}{l}\text { TOF }=593 \\
\text { mol catalyst } \\
{ }^{1} \mathrm{~h}^{-1}\end{array}$ & 206 \\
\hline & $\begin{array}{l}\text { Morpholog } \\
y- \\
\text { controlled } \\
\text { (rod, } \\
\text { hexagonal } \\
\& \quad \text { fiber) } \\
\text { synthesis }\end{array}$ & 275 & 4.3 & 0.42 & Oxidation & $\begin{array}{l}\text { Toluene } \\
\text { oxidation }\end{array}$ & $\begin{array}{l}\text { Catalyst }=200 \mathrm{mg} \text {, } \\
\mathrm{T}=230{ }^{\circ} \mathrm{C} \text {, Flow } \\
\text { rate }=50 \mathrm{~mL} / \mathrm{min} \\
\text { with } \quad 500 \mathrm{ppm} \\
\text { toluene }+20 \% \\
\mathrm{O}_{2} / \mathrm{Ar} \text { balance }\end{array}$ & $\begin{array}{l}90 \% \text { (rod), } \\
80 \% \\
\text { (hexagonal), } \\
60 \% \text { (fiber) } \\
\text { conversion }\end{array}$ & 207 \\
\hline
\end{tabular}
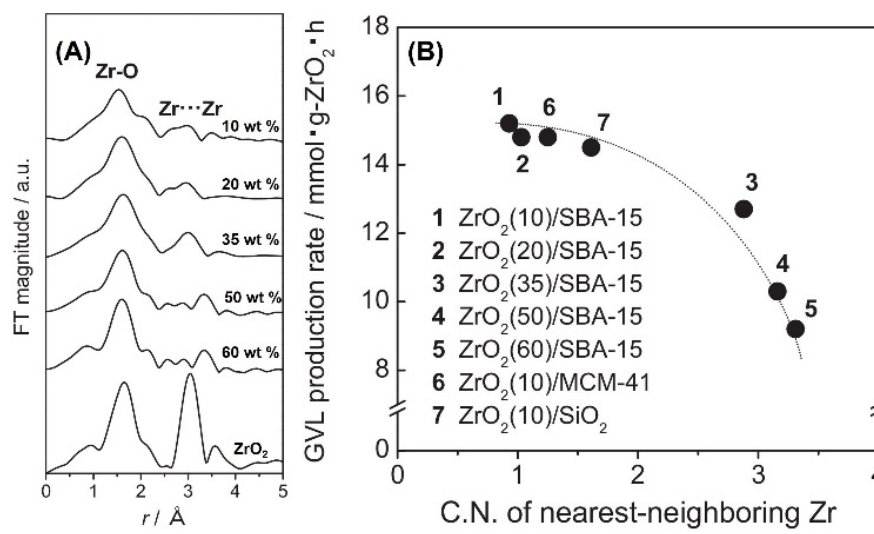

This journal is (C) The Royal Society of Chemistry 20xx
Fig. 11. (A) FT-EXAFS spectra of $\mathrm{ZrO}_{2} / \mathrm{SBA}-15$ with varied $\mathrm{ZrO}_{2}$ content and (B) Relationship of C.N. of Zr atoms and catalytic activities in the GVL production over silicasupported ZrO2 catalysts. Reproduced with permission from ref. [182] Copyright 2017 Elsevier.

T. Ressler et al. explored the CuO deposition on SBA-15 with different loadings of $\mathrm{Cu}$ for investigating the selective oxidation of propene to propylene oxide (PO) with gaseous oxygen. ${ }^{184}$ The present methods of $\mathrm{PO}$ production involve the use of hazardous chlorine and expensive hydroperoxides, also leading to the formation of many by-products. PO is an important chemical intermediate for various industries including polyurethane plastics and polyester resins. Cu catalysts exhibit good selectivity for $\mathrm{PO}$ in comparison to $\mathrm{Ag}$ or Au-based catalysts. In this report, $\mathrm{Cu}$ loading was varied from 1.1-19.4 wt \% resulting 
in different sizes of $\mathrm{CuO}$ particles on SBA-15. The surface area of SBA-15 was observed to be $756 \mathrm{~m}^{2} \mathrm{~g}^{-1}$ and it decreased significantly upon increasing the $\mathrm{Cu}$ loadings. The possible products observed in the propene oxidation reaction were $\mathrm{CO}_{2}$, $\mathrm{CO}$, acrolein, acetaldehyde, PO and others. During the initial course of the reaction, catalysts with 1.1 and $3.7 \mathrm{wt} \% \mathrm{Cu}$ loadings displayed negligible selectivity towards PO. The PO selectivity increased with $\mathrm{Cu}$ loading and maximum selectivity of $2.7 \%$ for CuO/SBA-15 (19.4 wt \%) was observed after $12 \mathrm{~h}$ of reaction time.

Thomas et al. investigated the catalytic conversion of methane to methanol for the first-time using $\mathrm{Cu}$ based catalysts supported on mesoporous silica SBA-15. ${ }^{185}$ Previously reported studies highlight the use of $\mathrm{Cu} /$ zeolites system to be the most promising catalyst for this process under mild reaction conditions. This paper utilizes the SBA-15 to form ultra-small nanoclusters of $\mathrm{CuO}$ which are uniformly dispersed within the framework. The catalyst (2.7 wt \%) was prepared by wet impregnation using $\mathrm{Cu}^{\prime \prime}$ acetylacetonate and $\mathrm{Cu}^{\prime \prime}$ acetate precursor solutions and labelled Cu-AA/SBA-15 and Cu-OA/SBA15 , respectively. The catalysis was initiated by activating the catalyst in oxygen at $550{ }^{\circ} \mathrm{C}$ and interacting the samples with methane at $200{ }^{\circ} \mathrm{C}$. Activated methane was converted to methanol after treatment with water. $30.2 \mu$ molg $^{-1}$ of methanol was formed with Cu-AA/SBA-15 and a smaller yield of 11.1 $\mu$ molg $^{-1}$ methanol was formed with $\mathrm{Cu}-\mathrm{OA} / \mathrm{SBA}-15$. Large-sized CuO particles $(30-60 \mathrm{~nm})$ deposited on silica were found to be inactive for this reaction. The ordered structure of SBA-15 is particularly advantageous for this reaction because it led to the formation of highly dispersed $\mathrm{CuO}$ nanoclusters with a uniform narrow-sized distribution. Moreover, the active site for the zeolite-based system has not been completely defined and CuO/SBA-15 system can be considered as the simple model to accelerate further studies on supported $\mathrm{CuO}$ species exploring the challenging direct conversion of methane to methanol.

Wang's group, for the first time, studied the structural oxygen defects and Lewis acidity in $\mathrm{WO}_{3} / \mathrm{SBA}-15$ prepared by the impregnation method using ammonium metatungstate hydrate as the precursor. ${ }^{186}$ The structural defects have been studied by theoretical simulation and acid sites by in situ Fourier-transform infrared (FTIR) technique. The catalysts with different loadings of $\mathrm{WO}_{3}$ (5-25 wt \%) on SBA-15 exhibited type IV isotherm with $\mathrm{H} 1$ hysteresis loop. The surface area of parent SBA-15 $\left(609 \mathrm{~m}^{2} \mathrm{~g}^{-1}\right)$ decreased to $396 \mathrm{~m}^{2} \mathrm{~g}^{-1}$ on increasing the loadings of $\mathrm{WO}_{3}$ to $25 \mathrm{wt} \%$. The surface chemical bonds and metal oxidation states were further characterized by Raman and XPS analysis. The oxidative removal of 4,6dimethyldibenzothiophene (DMDBT) in $n$-hexadecane was investigated as the model reaction to test the prepared catalysts. The superior catalytic performance was displayed by $15-25$ wt $\% \mathrm{WO}_{3}$ and was efficient in $99 \%$ removal of 4,6DMDBT at $60^{\circ} \mathrm{C}$. This report serves as an example of developing catalysts with defects and acid sites to oxidize sterically hindered organosulfur compounds.
(A)

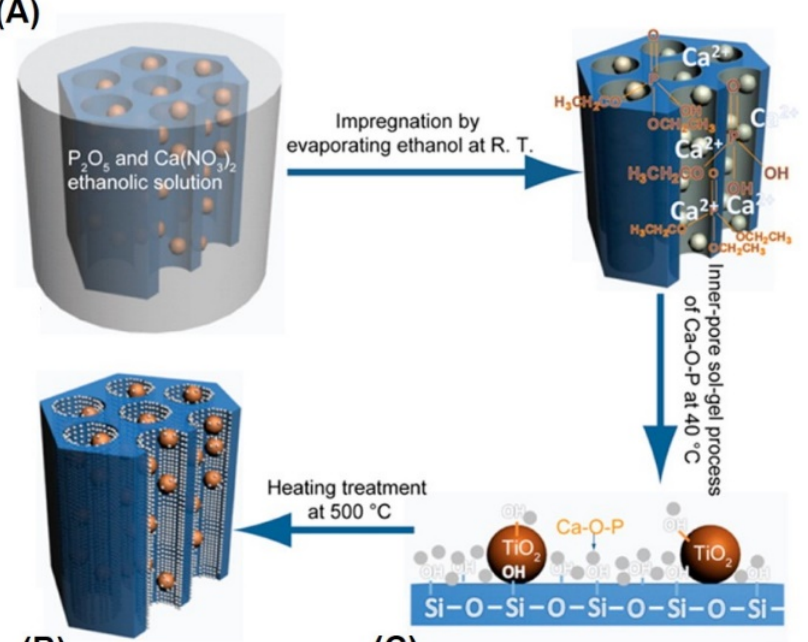

(B)

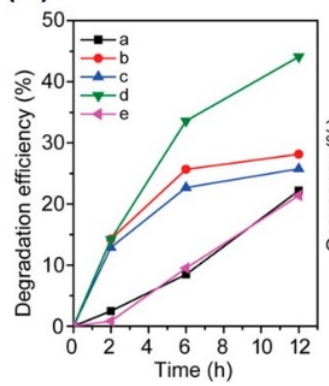

(C)

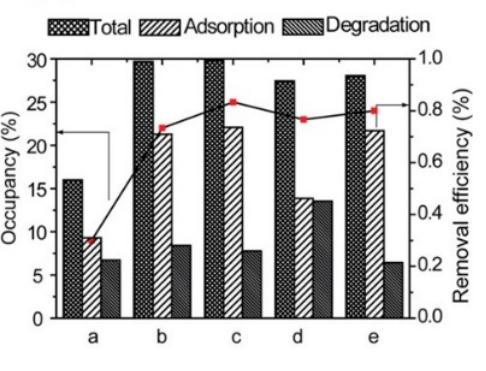

Fig. 12. (A) Schematic illustration of $\mathrm{CaP}$ coating in the mesoporous channels of $\mathrm{TiO}_{2} /$ SBA-15 by inner-pore sol-gel method, (B) Degradation efficiency as a function of time and (C) Degradation efficiency of methylene blue dye on (a) $\mathrm{TiO}_{2} / \mathrm{SBA}-15$, (b-d) $\mathrm{CaP}_{\mathrm{x}} @ \mathrm{TiO}_{2} / \mathrm{SBA}-15$ with increasing weight percentage $\mathrm{x}=4.6,9.4$ and 18.7 and (e) mixture $\mathrm{HAp}_{9.4}+\mathrm{TiO}_{2} / \mathrm{SBA}-15$. Reproduced with permission from ref. [183] Copyright 2013 American Chemical Society.

Behm et al. have investigated the effect of mesoporous silica in the $\mathrm{Au} / \mathrm{TiO}_{2}$ system for studying the low-temperature $\mathrm{CO}$ oxidation reaction. ${ }^{187}$ The surface of SBA-15 was coated with varying amounts of $\mathrm{TiO}_{2}$ monolayer and further $\mathrm{Au}$ NPs were deposited to develop Au/SBA-15-xTi catalytic system. The examples cited in the literature based on $\mathrm{Au} / \mathrm{TiO}_{2}$ system suffer from deactivation due to the accumulation of carbonate species on the interface of support and metal NPs leading to poisoning of the active sites. Many reported studies are focused on studying the activity of catalysts but not actually explaining the reason for the deactivation of the catalyst. Surface modification of SBA-15 was done by grafting procedure in which the precursor $\mathrm{Ti}\left(\mathrm{O}^{\mathrm{i} P r}\right)_{4}$ in dry toluene was added to the pre-treated SBA-15 followed by calcination at $500^{\circ} \mathrm{C}$. Au NPs were prepared by deposition-precipitation method to form Au/SBA-15-xTi catalysts $(x=0,7,12,15,17)$. These materials were tested in the $\mathrm{CO}$ oxidation activity at three different temperatures $\left(30^{\circ} \mathrm{C}\right.$, $80{ }^{\circ} \mathrm{C}$ and $180^{\circ} \mathrm{C}$ ) over $1000 \mathrm{~min}$. The activity was found to increase on increasing the Ti content in the catalyst whereas $\mathrm{Au} / \mathrm{SBA}-15$ displayed the least activity. This was explained due to (i) large-sized NPs $(6.1 \mathrm{~nm})$ of Au/SBA-15 in comparison to small-sized NPs (3.0-4.3 nm) of Au/SBA-15-xTi catalysts, (ii) inert nature of unmodified SBA-15 which doesn't provide active oxygen species needed for oxidation at the Au-support 
interface or (iii) other effects arising from the different composition of the support material. The authors have attributed the reasons for quick deactivation of the catalysts to the accumulation of adsorbed water leading to deactivation at lower temperatures like $30^{\circ} \mathrm{C}$. At higher temperatures $\left(180^{\circ} \mathrm{C}\right)$ where the molecularly adsorbed water is completely absent, they speculated a reversible reactive modification of the $\mathrm{TiO}_{x}$ deposit layer during $\mathrm{CO}$ oxidation.

Nakagaki's group has investigated a series of niobia functionalized mesoporous silica (Nb/SBA-15) solid catalysts. ${ }^{188}$ SBA-15 has been used to stabilize highly dispersed niobium species on the surface to carry out the efficient catalytic reaction. $\mathrm{Nb} / \mathrm{SBA}-15$ has been explored in a variety of chemical reactions from various research groups in Knoevenage condensation, biodiesel production and sucrose hydrolysis. ${ }^{189}$ 191 Despite such interest, these catalysts have never been explored for the esterification reaction. In this report, authors have explored the esterification of propanoic acid with methanol to study its potential for biodiesel production and further studied the significance of Lewis acidity in the catalytic activity. The $\mathrm{N}_{2}$ physisorption analysis confirmed the surface area of parent SBA-15 as $750 \mathrm{~m}^{2} \mathrm{~g}^{-1}$ and it decreased to $500 \mathrm{~m}^{2} \mathrm{~g}$ ${ }^{1}$ for the highest loading of $32 \mathrm{wt} \% \mathrm{Nb} / \mathrm{SBA}-15$. The UV-vis spectra displayed 2 strong absorption bands at $220 \mathrm{~nm}$ and 330 $\mathrm{nm}$ attributing to tetrahedral and octahedral $\mathrm{Nb}$ oxide species, respectively, coordinated with silica support material. $2 \mathrm{wt} \%$ of $\mathrm{Nb} / \mathrm{SBA}-15$ displayed the superior catalytic performance for the esterification reaction at $60^{\circ} \mathrm{C}$. This was supported by the TEM and acidity measurement studies which showed the highly dispersed $\mathrm{Nb}$ species possessing high acid content. Further, catalyst retains the stability after three runs due to the
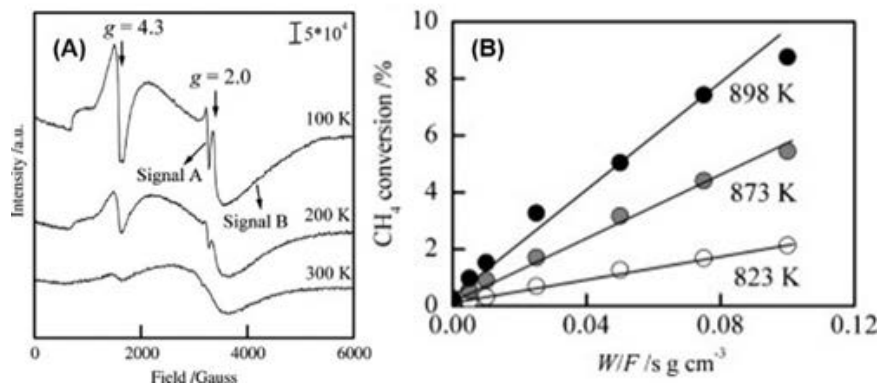

Fig. 13. (A) EPR spectra of $0.05 w \mathrm{wt} \% \mathrm{FeOx} / \mathrm{SBA}-15$ at different temperatures, (B) Catalytic conversion vs effect of contact time over $0.05 \mathrm{wt} \% \mathrm{FeOx} / \mathrm{SBA}-15$ catalyst at 823,873 and 898 K. Conditions: $\mathrm{W}=0.01-0.20 \mathrm{~g}, \mathrm{P}\left(\mathrm{CH}_{4}\right)=\mathrm{P}\left(\mathrm{O}_{2}\right)=33.8 \mathrm{kPa}, \mathrm{F}=120 \mathrm{~cm}^{3} \mathrm{~min}^{-1}$. Reproduced with permission from ref. [194] Copyright 2008 Elsevier.

formation of $\mathrm{Si}-\mathrm{O}-\mathrm{Nb}$ bonds between $\mathrm{Nb}$ precursor and surface silanol groups of the silica support.

In continuation of grafting different metal oxides on SBA-15, $M$. Yang et al. investigated the dispersion of bimetallic oxides within the channels of mesoporous silica by a post-grafting method. ${ }^{192}$ Prior to metal oxide deposition, the surface was modified by amine functional groups which assisted in the easy adsorption of precursors under ultrasonic conditions. The presence of $\mathrm{NiO}$ improves the dispersion of $\mathrm{CuO}-\mathrm{NiO}$ and hence improving the catalytic activity. XPS analysis concluded that the presence of $\mathrm{NiO}$ enhances the surface content of $\mathrm{CuO}$, and shifts in the binding energy values suggested the interaction between $\mathrm{Cu}$ and $\mathrm{Ni}$. These bimetallic oxides were tested in the epoxidation of styrene using tert-butyl hydroperoxide (TBHP) as the oxidant in acetonitrile at $80^{\circ} \mathrm{C}$. CuO-NiO/SBA-15 displayed $73 \%$ catalytic conversion of styrene with $83 \%$ selectivity for styrene oxide which was much higher than the results obtained by CuO/SBA-15 and NiO/SBA-15. This result was explained due to the synergistic interaction between $\mathrm{NiO}$ - promoted $\mathrm{CuO}$ system. Interestingly, small amounts of $\mathrm{Na}_{2} \mathrm{CO}_{3}$ addition leads to the $100 \%$ conversion of styrene and $92 \%$ selectivity of styrene epoxide. The authors further successfully tested the scope and adaptability of the catalysts by investigating different olefins and reaction rate follows the trend; trans-stilbene> trans- $\beta$-methylstyrene $>$ norbornene $>$ cis-Cyclooctene. This was accounted for the presence of electron-donating groups for making the double bonds more reactive in the epoxidation reaction.

Another similar bimetallic combination of metal oxide on mesoporous silica was synthesized by Grünert et al. for exploring the catalytic synthesis of methanol at 8 bar. ${ }^{193} \mathrm{CuO}$ and $\mathrm{ZnO}$ species were immobilized within the pores of SBA-15 and reduced under two different conditions (standard: $\mathrm{H}_{2}, 513$ $\mathrm{K}$ and severe: $\mathrm{CO} / \mathrm{H}_{2}, 673 \mathrm{~K}$ ). In all cases with different loadings of $\mathrm{Cu}$ and $\mathrm{Zn}$, a severe reduction method showed a superior reaction rate of $1.90 \mu \mathrm{molh}^{-1} \mathrm{~g}^{-1}$. This was attributed to the creation of oxygen deficiency in $\mathrm{ZnO}$ which interacts with surface $\mathrm{Cu}$ but also forms CuZn alloy NPs in small amounts. The promotional effect of $\mathrm{Cu}$ by $\mathrm{Zn}$ takes place via $\mathrm{Zn}^{2+}$ ions interacting with $\mathrm{Cu}$ surface to form undetectable amounts of CuZn alloy NPs.

As already discussed in the previous section about the merits of using SBA-15 as the support material, this report also emphasizes on the use of SBA-15 as catalyst support for selective oxidation reactions. ${ }^{194}$ The confinement effect of ordered mesoporous channels allows the uniform dispersion of $\mathrm{Fe}$ species and assists in controlling their growth to $\mathrm{FeO}_{x}$ nanoclusters. The surface inertness of SBA-15 and larger pore diameter $(\sim 6 \mathrm{~nm})$ makes it an ideal candidate for selective oxidation of $\mathrm{CH}_{4}$ to $\mathrm{HCHO}$. The parent SBA-15 displayed very low conversions of $0.3 \%$ at $898 \mathrm{~K} .0 .05$ wt $\%$ of $\mathrm{FeO}_{x}$ on SBA-15 enhanced the catalytic conversion to $5.0 \%$ with an $\mathrm{HCHO}$ yield of $1.9 \%$ at similar reaction conditions. The diffuse reflectance UV-vis spectra of catalysts with Fe loadings $<0.1 \mathrm{wt} \%$, a single absorption band at $250 \mathrm{~nm}$ was observed arising due to the ligand to metal charge transfer transition of $\mathrm{Fe}^{3+}$ species. EPR technique was typically found to be useful to study the type and state of active Fe species in the system as shown in Fig. 13 (A). The presence of $\mathrm{g}$ signal at 2.0 and 4.3 is attributed to the presence of three types of $\mathrm{Fe}$ species in $\mathrm{FeO}_{x} / \mathrm{SBA}-15$ i.e. isolated distorted tetrahedral $\mathrm{Fe}^{3+}$, isolated $\mathrm{Fe}^{3+}$ with high symmetry and $\mathrm{Fe}_{\mathrm{m}} \mathrm{O}_{\mathrm{n}}$ clusters. These active sites act as the active centers for $\mathrm{O}_{2}$ activation to generate active oxygen species for $\mathrm{CH}_{4}$ oxidation to $\mathrm{HCHO}$. Kinetic studies revealed that $\mathrm{CH}_{4}$ conversion increased on increasing the contact time (expressed as W/F: the ratio of catalyst weight (W) to the flow rate (F) (Fig. 13 (B)), however, the $\mathrm{HCHO}$ selectivity decreased 
with contact time or reaction temperature. The same research group has also investigated the catalytic performance using various transition metal oxide clusters, $\mathrm{MO}_{\mathrm{x}} / \mathrm{SBA}-15$ where $\mathrm{M}$ denotes $\mathrm{V}, \mathrm{Cr}, \mathrm{Mn}$, Fe, Co, Ni, $\mathrm{Cu}, \mathrm{Zn}, \mathrm{Mo}$ and $\mathrm{W}$ for $\mathrm{HCHO}$ formation. Other groups have also concluded the use of SBA-15 as the suitable support material for $\mathrm{CH}_{4}$ oxidation using $\mathrm{Mo}, \mathrm{V}$ or Fe oxides as the active metal oxides on silica. ${ }^{195-200}$

There are reports based on synthesizing iron-doped SBA-15 to introduce magnetic properties in the catalytic systems for easy recovery and separation. ${ }^{201,202}$ Vasile et al. studied the $\alpha$ $\mathrm{Fe}_{2} \mathrm{O}_{3}$ incorporated mesoporous silica, $\mathrm{MCM}-41$ displaying weak ferromagnetism at room temperature with slender hysteresis. The catalyst displayed $96 \%$ degradation efficiency of methylene blue dye and could be easily recovered by magnetic separation por centrifugation. ${ }^{203}$ Malakooti et al. explored the synthesis of $\mathrm{Fe}_{2} \mathrm{O}_{3} / \mathrm{SBA}-15$ in situ during the hydrothermal synthesis of SBA15 mesoporous silica. The magnetic property of silica was studied by measuring the hysteresis loop using vibrating sample magnetometer (VSM). The magnetization value of $40 \mathrm{emu} / \mathrm{g}$ was found to be strong enough to separate the catalysts from the reaction mixture using an external magnet. Further, the catalyst displayed superior catalytic performance in the oxidation of alcohols, sulfides and olefins along with stability and easy separation. ${ }^{204}$ Erdem et al. synthesized sulfonic acid functionalized SBA-15 containing superparamagnetic $\mathrm{Fe}_{3} \mathrm{O}_{4}$ NPs with particle size smaller than usual magnetic $\mathrm{Fe}_{2} \mathrm{O}_{3} \mathrm{NPs}^{205}$

Many research groups have studied the effect of different metals, composition and surface chemistry of supports for designing the catalysts for efficient formic acid ( $\mathrm{HCOOH})$ dehydrogenation. ${ }^{206} \mathrm{HCOOH}$ is considered as one of the most promising candidates for hydrogen storage materials because of its high hydrogen content (4.3 wt \%) and non-toxic nature. It can decompose in two different pathways as shown in equations 3 and 4.

\section{Dehydrogenation}

$\mathrm{HCOOH} \leftrightarrow \mathrm{H}_{2}+\mathrm{CO}_{2} \quad \Delta G=-48.4 \mathrm{~kJ} \mathrm{~mol}^{-1}$

Dehydration

$$
\mathrm{HCOOH} \leftrightarrow \mathrm{H}_{2} \mathrm{O}+\mathrm{CO} \quad \Delta G=-28.5 \mathrm{~kJ} \mathrm{~mol}^{-1}
$$

The catalyst $\mathrm{Pd}-\mathrm{MnO}_{\mathrm{x}} / \mathrm{NH}_{2}$-mesoporous silica in which $\mathrm{MnO}_{x}$ acts as the promotor for inhibiting $\mathrm{CO}$ production in the dehydration reaction. D-W. Lee et al. focused on tuning the pore structure of mesoporous silica for achieving superior catalytic performances in the hydrogen generation. Different mesoporous silica materials like KIE-6, MCM-41 and SBA-15 have been explored as a support and further KIE-6-a, b, $c$ and $d$ were prepared with different size of silica nanosphere in the framework by simply controlling the precursor concentration in the synthesis scheme. KIE-6 offers 3D disordered wormhole mesostructure whereas SBA-15 and MCM-41 have 2D ordered hexagonal structure with cylindrical pores. The pore size of KIE-

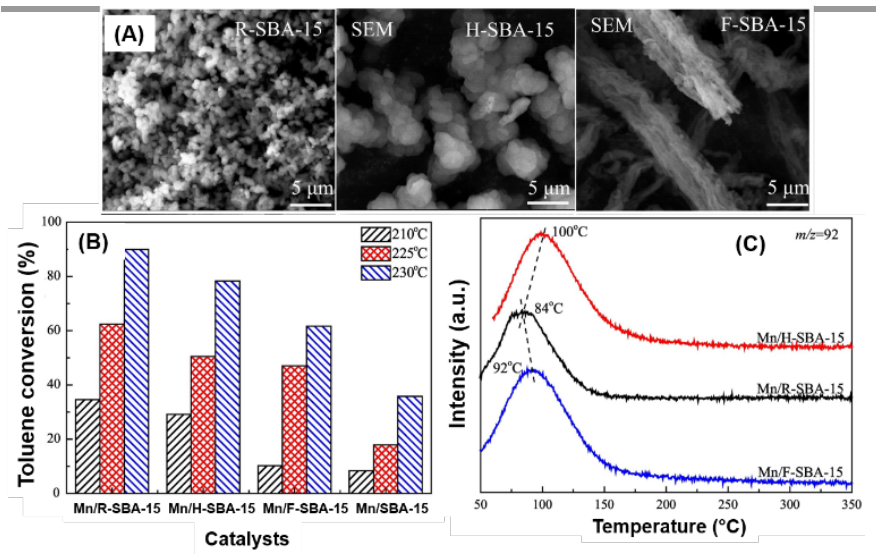

Fig. 14. (A) Scanning electron microscopy (SEM) images of three different morphology of SBA-15, R-SBA-15 (rod), H-SBA-15 (hexagonal) and F-SBA-15 (fiber), (B) Conversion of toluene at three different temperatures $\left(210,225\right.$ and $230^{\circ} \mathrm{C}$ for Mn/SBA-15 catalysts and (C) Temperature programmed desorption of toluene over different Mn/SBA-15 catalysts. $m / z$; mass-to-charge ratio. Reproduced with permission from ref. [207] Copyright 2018 Elsevier.

6 increased from 3.0 to $10.0 \mathrm{~nm}, \mathrm{SBA}-15$ with $5.8 \mathrm{~nm}$ and MCM41 displaying bimodal pore size distribution of small mesopores of $2.3 \mathrm{~nm}$ and larger pores of $64.0 \mathrm{~nm}$ arising from the interstitial voids. The catalytic performance of supported Pd and $\mathrm{MnO}_{x}$ NPs immobilized on amine-functionalized mesoporous silica was investigated at $25{ }^{\circ} \mathrm{C}$. The catalysts prepared on support $\mathrm{NH}_{2}$-SBA-15 displayed lowest catalytic performance and $\mathrm{NH}_{2}$ - $\mathrm{KIE}-6$-c gave the highest activity with TOF $593 \mathrm{~mol}^{\text {catalyst }}{ }^{-1} \mathrm{~h}^{-1}$. It was deduced that 3D interconnected pore structure is preferable for better mass transfer of liquid phase formic acid than 2D cylindrical structure. Considering the similar morphology and surface area of support materials, larger pore size and pore volume would be beneficial to achieve superior catalytic performances.

$\mathrm{Q}$ 's group explored the synthesis of different morphologies of mesoporous silica i.e. $\operatorname{rod}(\mathrm{R})$, hexagonal $(\mathrm{H})$ and fiber $(\mathrm{F})$ like SBA-15 as a support material for $\mathrm{MnO}_{\mathrm{x}}$ deposition. ${ }^{207}$ The morphology of SBA-15 was controlled by varying different factors like aging time, $\mathrm{ZrOCl}_{2}$ addition, stirring speed and time from 24 to $48 \mathrm{~h}$. Mn was further deposited by precipitation method using $\mathrm{Mn}\left(\mathrm{NO}_{3}\right)_{2}$ as the precursor solution to form Mn/R-SBA-15, Mn/H-SBA-15 and Mn/F-SBA-15. SEM and TEM images confirmed the structural differences in the morphology and size of particles as shown in Fig. 14 (A). Mn catalyst supported on rod-like morphology displayed superior catalytic performance for toluene oxidation following the order; Mn/RSBA-15 > Mn/H-SBA-15 > Mn/F-SBA-15> Mn/commercial SBA15 (Fig. 14 (B)). Further, temperature-programmed desorption (TPD) measurement was carried out to display the interaction of toluene with catalysts as shown in Fig. 14 (C). The lowest desorption temperature of $\mathrm{Mn} / \mathrm{R}-\mathrm{SBA}-15$ suggested the easy diffusion of toluene molecules since rods have more mesochannel openings which assist in the adsorption of reactants.

3.4 Miscellaneous species incorporated in SBA-15 
After exploring the effect of heteroatom deposition (such as metal oxides, metal NPs and single-site heteroatoms within the framework), this section compiles the recent reports investigating the variety of species immobilized on SBA-15 such as transition metal-based complexes, fullerene, zeolites and metal-organic frameworks (MOFs) as also summarized in Table 6.

Metal-organic frameworks (MOFs) have gained significant attention in the recent past due to their promising and diverse applications in catalysis, drug delivery, gas separation and so on. However, their poor stability towards moisture hinders their applications commercially. Even traces of water can disrupt the metal-coordination bonding and destabilize the framework. As we have already discussed the applications and advantages of mesoporous silica, this study explores the MOFs incorporation within the nanopores of silica to reduce the crystal size and enhance the mass-transport ability. Sun's group reported a double solvent strategy whereby the interfacial tension between non-polar solvent and polar solution (with MOF precursor) directs the precursor to enter hydrophilic mesopores of silica as illustrated in Fig. 15 (A). ${ }^{208}$ Fig. 15 (B, C) displays the SEM and TEM images of MOF-5, MOF-5@SBA-15 and SBA-15 materials along with STEM image and elemental mapping of $\mathrm{Si}$, $\mathrm{O}$ and $\mathrm{Zn}$ for the MOF-5@SBA-15 composite. As evident from the STEM image, mesoporous silica preserved its hexagonal ordered structure and shape of the pores even after MOF incorporation. The MOF-5@SBA-15 composite was found to be more hydro-stable and preserved the symmetry of silica support. The prepared composite was tested in the FriedelCrafts alkylation reaction of benzyl bromide with toluene. SBA15 was found to be inactive, MOF- 5 displayed $61 \%$ conversion and MOF-5@SBA-15 composite reached $100 \%$ conversion in 3 $h$ as shown in Fig. 15 (D). This observation suggests the effect of confining MOF-5 within the nanopores of SBA-15 for achieving significantly higher catalytic performances. The stability tests showed $85 \%$ conversion after three cycling steps which is slightly lower than the fresh catalyst. The authors have also explored the possibility of confining other MOFs (i.e. HKUST-1 and ZIF-8) by double solvent strategy. We found this report particularly interesting because it sheds light on combining nanomaterials to form composites with improved stability and catalytic applications.

Zhang et al. studied the morphology-controlled mesoporous silica by confining Au NPs on zeolite containing silica, ZSM5/SBA-15 (ZSBA). ${ }^{209} \mathrm{Au} / \mathrm{ZSM}-5$ seeds were added along with the dropwise addition of TEOS (Si source) in the typical synthesis of SBA-15 to obtain hexagonal prism Au/ZSBA-HP. The addition of glycerol gave rod $\mathrm{Au} / \mathrm{ZSBA}-\mathrm{RD}$ and $\mathrm{ZrOCl}_{2} \cdot 8 \mathrm{H}_{2} \mathrm{O}$ addition led to the synthesis of platelet Au/ZSBA-PL. For reference, Au/SBA-15 was also prepared by the incipient impregnation method. The average size of Au NPs on morphology-controlled ZSBA-15 was measured to be 4-4.5 $\mathrm{nm}$, whereas Au/SBA-15 formed larger NPs size of $9.3 \mathrm{~nm}$. The pseudo-first-order kinetics of nitrophenol reduction reaction follows the trend; $\mathrm{Au} / \mathrm{ZSBA}-\mathrm{PL}>$ $\mathrm{HP}>\mathrm{RD}$ with the highest reaction rate constant of $0.14 \mathrm{~min}^{-1}$.

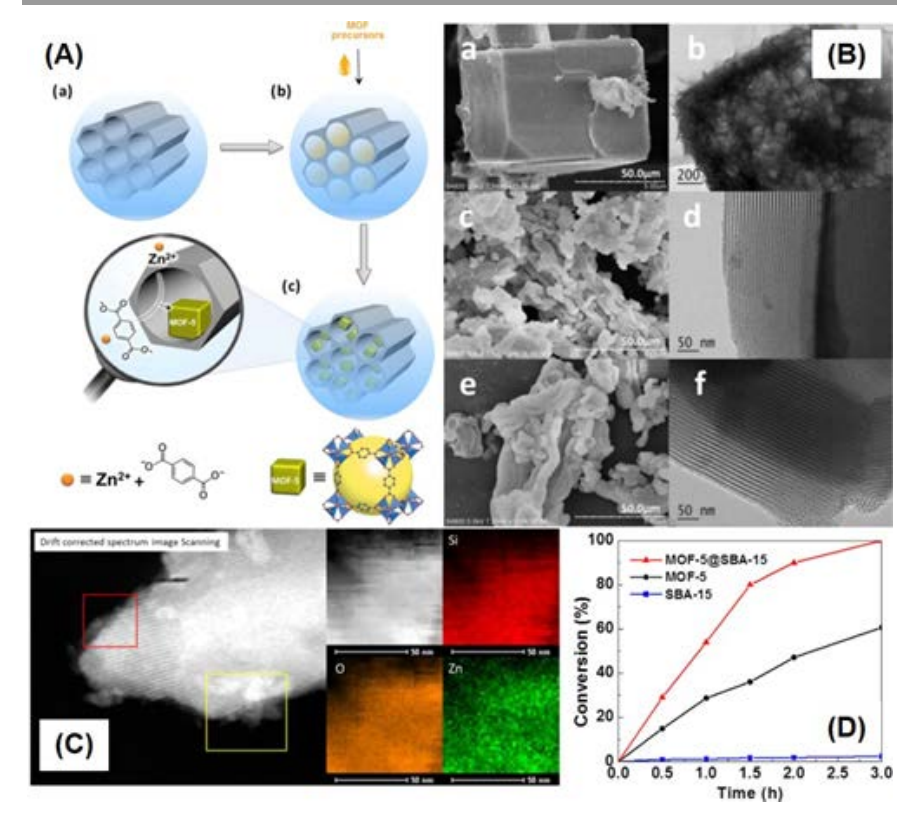

Fig. 15. (A) MOF incorporation in SBA-15 using double-solvent strategy, (B) SEM and TEM micrographs of (a, b) MOF-5, (c, d) MOF-5@SBA-15, (e, f) SBA-15, (C) STEM image of MOF-5@SBA-15 with elemental mapping and (D) Conversion of Friedel-Crafts alkylation of benzyl bromide with toluene. Reproduced with permission from ref. [208] Copyright 2018 American Chemical Society.

Different catalytic activities were explained due to difference in the pore size and length of mesochannels of the support materials. The larger pore diameter $(6.7 \mathrm{~nm})$ and shorter mesochannel length $(210 \mathrm{~nm})$ of platelet support $(\mathrm{PL})$ leads to the better diffusion and superior catalytic performance than rod (RD) and hexagonal prism (HP) catalysts.

To overcome the drawbacks of homogeneous catalysts such as stability and separation from reaction media, organometallic complexes have been immobilized onto solid support materials through the covalent bond formation. ${ }^{210}$ Such metal complexes grafted on support materials have been proven to reduce metal leaching and prevent contamination of products thereby enhancing the catalytic activity and selectivity in contrast to homogeneous complexes. ${ }^{211-218}$ In the study reported by Yang's group, the local structure of Rh complex (Wilkinson's complex, $\left.\mathrm{RhCl}\left(\mathrm{PPh}_{3}\right)_{3}\right)$ was immobilized on amine-functionalized SBA-15 as illustrated in Fig. 16 (A). The surface differences before and after grafting were studied by solid-state NMR $\left({ }^{13} \mathrm{C},{ }^{29} \mathrm{Si}\right.$ and $\left.{ }^{31} \mathrm{P}\right)$, XPS and EXAFS (Fig. 16 (B, C)) analysis. This deposition led to the positive effects in the catalysis of $\mathrm{C}$ - heteroatom bond formation for the addition of alkynes with thiols or sulfonic acid. The product selectivity (regio- and stereo-) dependent on the local structure of Rh complex grafted on mesoporous silica.

Another interesting report addressing the issue of reusability and recovering of the homogenous catalyst after the reaction by heterogenizing the molecular catalyst. ${ }^{219}$ An inorganic Fe-based complex, tetrairon (III)-substituted polyoxotungstate $\left[\mathrm{Fe}_{4}\left(\mathrm{H}_{2} \mathrm{O}\right)_{2}\left(\mathrm{P}_{2} \mathrm{~W}_{15} \mathrm{O}_{56}\right)_{2}\right]^{12-} \quad\left(\mathrm{Fe}_{4} \mathrm{POM}\right)$ is instrumental in carrying out photocatalytic water oxidation reaction under visible light irradiation with $\mathrm{O}_{2}$ yield of $48 \%$ and 
Table 6. Catalytic systems with miscellaneous species incorporated in mesoporous silica, SBA-15

\begin{tabular}{|c|c|c|c|c|c|c|c|c|c|}
\hline \multirow[b]{2}{*}{$\begin{array}{l}\text { Descriptor } \\
\text { (Hybrids) }\end{array}$} & \multirow{2}{*}{$\begin{array}{c}\text { Sub- } \\
\text { descriptor }\end{array}$} & \multicolumn{3}{|c|}{$\begin{array}{c}\text { Physicochemical } \\
\text { properties }\end{array}$} & \multirow{2}{*}{$\begin{array}{l}\text { Reaction } \\
\text { Type }\end{array}$} & \multirow[b]{2}{*}{$\begin{array}{l}\text { Catalytic } \\
\text { reaction }\end{array}$} & \multirow{2}{*}{$\begin{array}{l}\text { Reaction } \\
\text { conditions }\end{array}$} & \multirow{2}{*}{$\begin{array}{c}\text { Catalytic } \\
\text { performan } \\
\text { ce }\end{array}$} & \multirow[b]{2}{*}{ Ref. } \\
\hline & & $\begin{array}{c}\text { Surface } \\
\text { area } \\
\left(\mathrm{m}^{2} / \mathrm{g}\right)\end{array}$ & $\begin{array}{l}\text { Pore } \\
\text { size } \\
(\mathrm{nm}) \\
\end{array}$ & $\begin{array}{c}\text { Pore } \\
\text { volume } \\
\left(\mathrm{cm}^{3} / \mathrm{g}\right)\end{array}$ & & & & & \\
\hline MOF-5/SBA-15 & $\begin{array}{l}\text { Double- } \\
\text { solvent } \\
\text { strategy }\end{array}$ & 571 & 8 & 0.68 & $\begin{array}{l}\text { Substituti } \\
\text { on }\end{array}$ & $\begin{array}{l}\text { Friedel Crafts } \\
\text { alkylation } \\
\text { reaction }\end{array}$ & $\begin{array}{l}\text { Catalyst }=100 \\
\mathrm{mg}, \mathrm{T}=80^{\circ} \mathrm{C}, \\
\mathrm{t}=3 \mathrm{~h}\end{array}$ & $\begin{array}{c}100 \% \\
\text { conversion }\end{array}$ & 208 \\
\hline ZSM/SBA-15 & $\begin{array}{l}\text { Morphology } \\
\text { controlled } \\
\text { (prism, rod } \\
\text { and platelet) }\end{array}$ & 685 & 6.7 & 0.85 & $\begin{array}{l}\text { Hydrogen } \\
\text { ation }\end{array}$ & $\begin{array}{l}\text { Hydrogenation } \\
\text { of } p \text { - } \\
\text { nitrophenol ( } p \text { - } \\
\text { NP) to } p \text { - } \\
\text { aminophenol }\end{array}$ & $\begin{array}{lr}25 \quad \mu \mathrm{L} & \text { of } \\
0.01 \mathrm{M} \quad p-\mathrm{NP} \\
\text { and } 0.01 \quad \mathrm{M} \\
\mathrm{NaBH}_{4} \text { as } \\
\text { reducing } \\
\text { agent }\end{array}$ & $\begin{array}{l}\text { Rate } \\
\text { constant } k= \\
0.14 \quad \mathrm{~min}^{-1} \\
\text { (platelet) } \\
0.05 \mathrm{~min}^{-1} \\
\text { (prism) and } \\
0.02 \mathrm{~min}^{-1} \\
\text { (rod) }\end{array}$ & 209 \\
\hline $\begin{array}{c}\mathrm{Rh} \\
\text { complex/SBA- } \\
15\end{array}$ & $\begin{array}{c}\text { Amine } \\
\text { functionalizat } \\
\text { ion }\end{array}$ & 315 & 5.8 & 0.43 & Addition & $\begin{array}{l}\text { C-heteroatom } \\
\text { bond } \\
\text { formation for } \\
\text { the addition of } \\
\text { alkynes }\end{array}$ & $\begin{array}{l}\text { Catalyst }=50 \\
\mathrm{mg}, \mathrm{t}=24 \mathrm{~h}, \\
\mathrm{~T}=25{ }^{\circ} \mathrm{C}, \\
\text { Solvent: } \\
\text { dichloroetha } \\
\text { ne }\end{array}$ & $96 \%$ yield & 210 \\
\hline $\begin{array}{c}\mathrm{Fe}_{4} \mathrm{POM} \\
\text { complex/SBA- } \\
15\end{array}$ & $\begin{array}{c}\text { Amine } \\
\text { functionalizat } \\
\text { ion }\end{array}$ & -- & -- & -- & Oxidation & $\begin{array}{l}\text { Photocatalytic } \\
\text { water } \\
\text { oxidation }\end{array}$ & $\begin{array}{l}16 \mathrm{~mW} \text { LED }(\lambda \\
>\quad 420 \mathrm{~nm}), \\
1.0 \quad \mathrm{mM} \\
{\left[\mathrm{Ru}(\mathrm{bpy})_{3}\right] \mathrm{Cl}_{2},} \\
5.0 \quad \mathrm{mM} \\
\mathrm{Na}_{2} \mathrm{~S}_{2} \mathrm{O}_{8}, \quad 80 \\
\mathrm{mM} \text { sodium } \\
\text { borate buffer } \\
\text { (pH 9.0) }\end{array}$ & $\begin{array}{c}\text { Quantum } \\
\text { yield }=24 \%\end{array}$ & 219 \\
\hline $\begin{array}{c}\mathrm{Ir} \\
\text { complex/SBA- } \\
15\end{array}$ & $\begin{array}{c}\text { Phosphoresc } \\
\text { ence } \\
\text { intensity }\end{array}$ & 959 & 7.1 & 1.35 & Oxidation & $\begin{array}{l}\text { Photocatalytic } \\
\text { oxidation of } \\
\text { trans-stilbene } \\
\text { and 1- } \\
\text { naphthol using } \\
\mathrm{O}_{2}\end{array}$ & $\begin{array}{l}\text { Catalyst }=20 \\
\mathrm{mg}, \mathrm{CH}_{3} \mathrm{CN}= \\
10 \mathrm{~mL}, \\
\text { substrate = } \\
0.04 \text { mmol, } \\
\mathrm{O}_{2}=1 \text { atm, t= } \\
24 \mathrm{~h}, \lambda>420 \\
\mathrm{~nm}\end{array}$ & $\begin{array}{l}\text { TON = } 8 \\
\text { (trans- } \\
\text { stilbene) } \\
\text { and TON= } 79 \\
\text { (1-naphthol) }\end{array}$ & 220 \\
\hline $\mathrm{C}_{60} / \mathrm{SBA}-15$ & $\begin{array}{c}\text { Photo- } \\
\text { assisted Ru } \\
\text { deposition }\end{array}$ & 433 & 8.3 & 0.80 & $\begin{array}{l}\text { Dehydrog } \\
\text { enation }\end{array}$ & $\begin{array}{l}\text { Hydrogen } \\
\text { production } \\
\text { from ammonia } \\
\text { borane }\end{array}$ & $\begin{array}{l}\mathrm{T}=25^{\circ} \mathrm{C}, \mathrm{t}= \\
0.5 \mathrm{~h}\end{array}$ & $\begin{array}{l}100 \quad \% \\
\text { conversion, } \\
\text { TOF = } 370 \\
\text { min }^{-1}\end{array}$ & 224 \\
\hline
\end{tabular}

Quantum yield of $24 \% . \mathrm{Na}_{2} \mathrm{~S}_{2} \mathrm{O}_{8}$ and $\left[\mathrm{Ru}(\mathrm{bpy})_{3}\right] \mathrm{Cl}_{2}$ were used as sacrificial electron acceptor and photosensitizer, respectively. The photocatalytic water oxidation cycle in the presence of photosensitizer and electron acceptor is shown in Fig. 17 (A). In order to reuse the catalysts, the $\mathrm{Fe}_{4} \mathrm{POM}$ was immobilized on amine-functionalized SBA-15 by electrostatic interactions. The $\mathrm{O}_{2}$ evolution was significantly enhanced by increasing the concentration of $\mathrm{Fe}_{4} \mathrm{POM}$ in the reaction mixture from 0 to $3.0 \mu \mathrm{M}$ and then decreased for $5.0 \mu \mathrm{M}$ as shown in Fig. 17 (B). SBA-15 immobilized $\mathrm{Fe}_{4} \mathrm{POM}$ could be easily recovered from the reaction mixture and used several times without any loss of activity (Fig. 17 (C)). This report can prove to be the one amongst the very few reports for designing the recyclable water oxidation catalyst using a homogeneous POM catalyst. 
Our group has also reported the anchoring of Ir based complex [Ir(Mebib)(ppy)Cl] (Mebib: bis(Nmethylbenzimidazolyl)pyridine, ppy: phenylpyridine) on the amine functionalized mesoporous materials (SBA-15, MCM-48 and MCM-41) for photocatalytic oxidation of trans-stilbene and 1-naphthol. The intensity of phosphorescence emission at 530 $\mathrm{nm}$ increases in the following order MCM- $41<\mathrm{MCM}-48<\mathrm{SBA}-$ 15 , which follows the same trend in the catalytic activity. ${ }^{220}$ $[\mathrm{Pt}(\mathrm{tpy}) \mathrm{Cl}] \mathrm{Cl}$ (tpy: terpyridine) complex was also anchored on amine-functionalized mesoporous silica materials for liquid phase oxidation of styrene and $\mathrm{H}_{2}$ evolution reaction in the presence of ethylenediaminetetraacetic acid (EDTA) as the sacrificial electron donor. ${ }^{221,222}$

The typical synthesis of mesoporous silica, SBA-15 usually involves the use of strong acid such as $\mathrm{HCl}$ to hydrolyze and condense the silica species. This report from Yu's group explores the acid-free synthesis of SBA-15 and investigated the Fe incorporated SBA-15 which is usually difficult due to easy cleavage of $\mathrm{Fe}-\mathrm{O}-\mathrm{Si}$ bonds. ${ }^{223}$ The synthesis was initiated by using TEOS- $\mathrm{P}_{123}-\mathrm{H}_{2} \mathrm{O}$ system under UV-light $\left(3 \mathrm{Wm}^{-2}\right)$ irradiation forming $\mathrm{OH}$ radicals at $313 \mathrm{~K}$. An ordered structure with type IV isotherm in the $\mathrm{N}_{2}$ physisorption confirmed the 2D-hexagonal mesoporous structure. The synthesis of Fe-SBA-15 was also investigated by using Fenton reagent which gives $\cdot \mathrm{OH}$ radicals and acts as the source of introducing Fe into the system. Low angle XRD, TEM and $\mathrm{N}_{2}$ physisorption further confirmed the ordered mesostructure with rope-like morphology. The presence of hydroxyl radicals was confirmed by electron

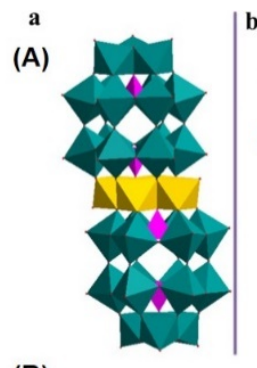

(B)

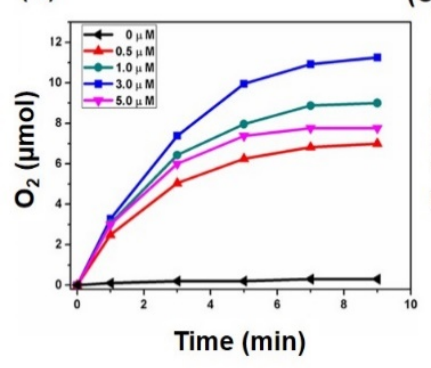

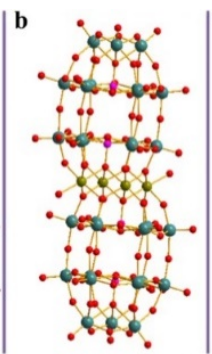

(C)

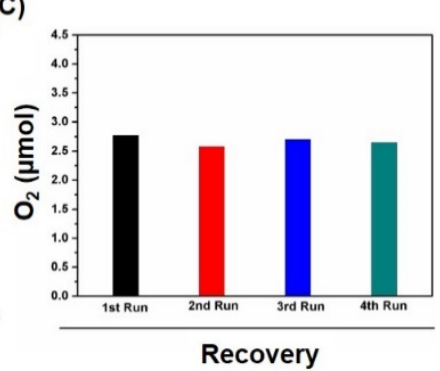

Fig. 17. (A) (a) Polyhedral and (b) ball-and-stick representation of $\mathrm{Fe}_{4} \mathrm{POM}$. Color scheme $\left[\mathrm{Fe}_{4} \mathrm{O}_{14}\left(\mathrm{H}_{2} \mathrm{O}\right)_{2}\right]$ polyhedra (yellow); $\mathrm{Fe}$ (cyan), W (dark blue), $\mathrm{O}$ (red). (c) The photocatalytic water oxidation cycle in the presence of catalyst, photosensitizer and electron acceptor, (B) Reaction kinetics of $\mathrm{O}_{2}$ evolution at different concentration of $\mathrm{Fe}_{4} \mathrm{POM}$ under light irradiation conditions and (C) Stability tests in the $\mathrm{O}_{2}$ evolution reaction using SBA-15-apts-Fe ${ }_{4} \mathrm{POM}$ catalyst. Conditions: $16 \mathrm{~mW}$ LED lamp equipped with a cut off filter $(\lambda \geq 420 \mathrm{~nm})$; total reaction volume is $10 \mathrm{~mL}$ and overall volume is $\sim 23.3 \mathrm{~mL}$; catalyst concentration $(0-5.0 \mu \mathrm{M}), 1.0 \mathrm{mM}\left[\mathrm{Ru}(\mathrm{bpy})_{3}\right] \mathrm{Cl}_{2}, 5.0 \mathrm{mM} \mathrm{Na}_{2} \mathrm{~S}_{2} \mathrm{O}_{8}, 80$ $\mathrm{mM}$ sodium borate buffer (initial $\mathrm{pH}$ 9.0); vigorous agitation using a magnetic stirrer. Reproduced with permission from ref. [219] Copyright 2018 Elsevier. paramagnetic resonance (EPR) signals which were measured in situ after irradiating the mixture for $1 \mathrm{~min}$. Unlike conventional synthesis, this radical route is environment-friendly, simple and facile for the preparation of ordered mesoporous silica with high surface area.

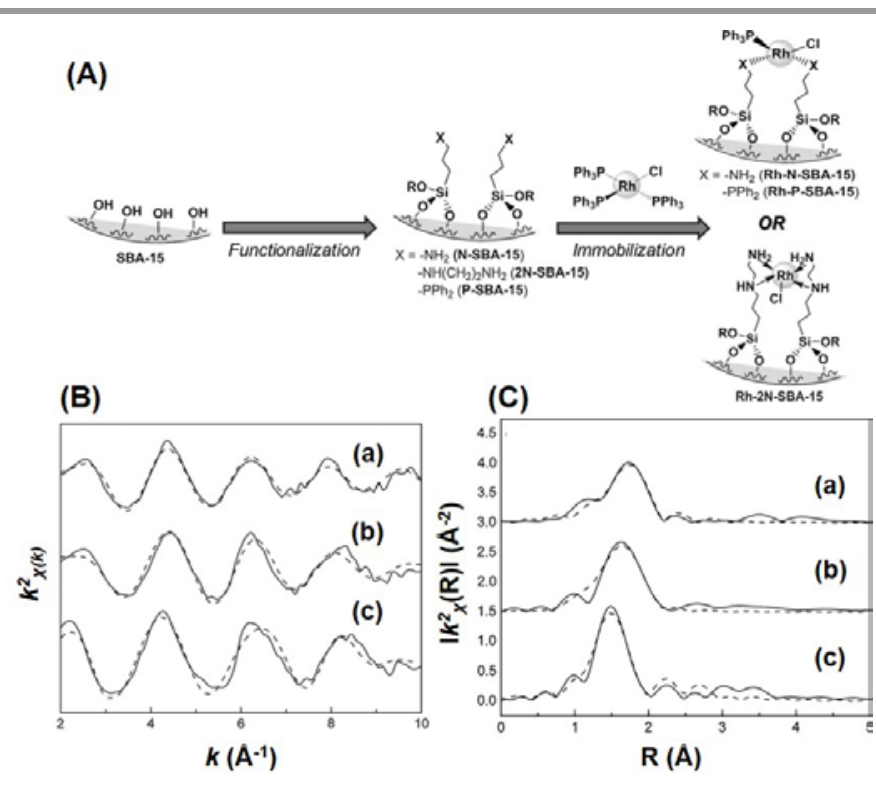

Fig. 16. (A) Illustration of immobilizing Rh complexes on functionalized SBA-15, (B) $k^{2}$ weighted and (C) Fourier-transform of Rh $K$-edge EXAFS spectra of Rh-based SBA-15 catalysts for (a) Rh-P-SBA-15, (b) Rh-N-SBA-15 and (c) Rh-2N-SBA-15. Reproduced with permission from ref. [210] Copyright 2018 Elsevier.
In this report from our group, fullerene $\left(C_{60}\right)$ was introduced within the mesopores of SBA-15, which can act as the anchoring site to reduce the ionic Ru species to uniformly dispersed $\mathrm{Ru}$ metal NPs. ${ }^{224}$ Upon light irradiation, fullerene $C_{60}$ gets excited and provides a reduction site for $\mathrm{Ru}^{3+}$ ions within the mesopores of SBA-15. The average size of Ru NPs in $\mathrm{Ru} / \mathrm{C}_{60}(10) / \mathrm{SBA}-15$ was $4.8 \mathrm{~nm}$, while $\mathrm{Ru} / \mathrm{SBA}-15$ displayed a bimodal size distribution of $4 \mathrm{~nm}$ for NPs deposited within the mesopores and $10 \mathrm{~nm}$ for the aggregated NPs formed on the external surface. The catalytic performance was tested in the hydrogen production from ammonia borane. The highest TOF values calculated after $5 \mathrm{~min}$ of reaction time was observed to be $370 \mathrm{~min}^{-1}$ for $\mathrm{Ru} / \mathrm{C}_{60}(20) / \mathrm{SBA}-15$, which was 2.2 times higher than that of the $\mathrm{Ru} / \mathrm{SBA}-15$. The enhanced catalytic activity was explained due to the highly dispersed small-sized Ru NPs with the effect arising from $\mathrm{C}_{60}$ molecules. This research study concludes the unique application of $\mathrm{C}_{60}$ molecules as the site for NPs reduction.

\section{Conclusions and future perspectives}

The discovery of SBA-15 has stimulated research studies on 'host-guest' chemistry within the channels of SBA-15 for its potential applications in catalysis, adsorption, drug-delivery, sensors and nanomaterial fabrication. In this review, we have concluded a detailed and systematic evaluation of heteroatom doped mesoporous silica for their recently published catalytic 
applications. We must emphasize here that most of the encountered reviews in this field report the overview, new synthetic methods, specific metal based catalysis (for example; Au-based or Pt-based) or targeting a particular catalytic reaction (for example; oxidation, hydrogenation, coupling and so on), while very limited examples are based on evaluating functionalized mesoporous silica and their catalytic performance, which is closely aligned with specific descriptors, for a variety of emerging applications for wider readership. In this paper, we specifically review the advanced methods of designing functionalized mesoporous silica, SBA-15. A vast variety of catalytic applications on SBA-15 have been summarized with a view to linking design strategies of mesoporous silica-based materials. The structure-property links of the catalytic systems has been summarized (in Tables 3-6) by correlating their physicochemical properties, reaction conditions and catalytic performances. To the best of our knowledge, we have not encountered a review paper, which specifically links catalytic descriptors with advances in synthesis, particularly relating to emerging applications.

Heterogeneous catalysis is one of the most extensively studied applications of the designed materials. The SBA-15 based composite materials are promising heterogeneous catalysts because of their excellent and versatile catalytic applications in oxidation, reduction, coupling, photodegradation and adsorption processes. Recent years have seen significant growth in using mesoporous silica support materials such as MCM-41, MCM-48, SBA-15, SBA-16 and HMS. SBA-15 has proven to be the better catalyst support material because of its noteworthy and desirable properties such as two-dimensional (2D) hexagonal porous structure, high surface area, tunable pore diameter and strong pore wall leading to thermal and mechanical stability.

This review puts an emphasis on the synthesis and tuning of the morphology of SBA-15 followed by its surface functionalization by different functional groups. Functionalization of SBA-15 makes it more stable and active particularly for organic reactions than the pure SBA-15. A brief discussion on heteroatom incorporation in SBA-15 has been compiled by citing the recently published articles in this field by exploring the variety of catalytic reactions like epoxidation of alkenes, biodiesel production, $\mathrm{NH}_{3}$ synthesis, pollutant degradation, $\mathrm{CO}_{2}$ adsorption, esterification, $\mathrm{CH}_{4}$ reforming, soot combustion, water splitting and so on. Heteroatom incorporation includes developing single-site catalysts ( $\mathrm{Ti}, \mathrm{Zr}$, $\mathrm{Mo}, \mathrm{Co}$ ) within the framework, metal NPs ( $\mathrm{Ni}, \mathrm{Mn}, \mathrm{Co}, \mathrm{Ag}, \mathrm{Au}$, $\mathrm{Pd}, \mathrm{Pt}, \mathrm{Ru}$ ) within the mesopores of silica and developing metal oxides $\left(\mathrm{CuO}, \mathrm{TiO}_{2}, \mathrm{WO}_{3}, \mathrm{NiO}, \mathrm{ZnO}, \mathrm{Fe}_{2} \mathrm{O}_{3}\right)$ on the surface of SBA15. The surface modification of SBA-15 allows not only the regeneration of the catalysts but also superior catalytic performances in comparison to the homogeneous analogues. The critical issue of leaching of metal complexes in homogeneous catalysis can be resolved and reused for 6-7 cycles without any loss of activity. This can be attributed to the creation of new geometries and modified electronic states in a confined nanospace upon immobilization on the silica surface.
Also, increased stability due to site isolation and higher substrate density around the active site contributes to the enhanced catalytic performance. Further, the increased accessibility of substrate molecules because of enhanced diffusion rates further adds on to the higher catalytic performance of SBA-15 catalysts. The different morphology of metal incorporated SBA-15 has also been included along with the recent study on intercalating metal NPs in the walls of silica for enhanced catalytic applications than the conventionally prepared catalyst. Incorporation of miscellaneous species in silica, for example, metal-organic frameworks (MOFs), zeolites and fullerene has also been briefly discussed.

From our perspective, there are several ideas for future research direction in this field. Several studies have reported the inherent stability and recyclability of supported catalysts, however, some functionalized silica supported metal NPs undergo sintering, changes in the morphology and particle size, depending on the type of reaction conditions, synthetic procedure and nature of metal. Further, detailed research coupled with theoretical calculations are required to study and predict the behavior of such catalytic systems. Despite the rapid advancements in nanotechnology, development of sophisticated methods for synthesizing M-SBA-15 catalysts (M: transition metal deposited on the surface or doped within the framework) are needed for applications beyond laboratory scale. The challenges for designing easy and inexpensive M-SBA15 catalysts are the high energy consumption and increased cost of surface modification for obtaining catalysts with significantly high catalytic activity, selectivity and stability. Moreover, in order to control and understand the growth mechanism of metal NPs on mesoporous support materials, it is essential to develop synthetic protocols by varying the parameters like reducing agent, solvent, temperature and pressure conditions. Finally, in order to make a paradigm shift towards more sustainable applications of M-SBA-15, it is important to explore photocatalytic approaches by employing solar light irradiation for enhanced activities in real applications like water splitting, waste-water treatment and solar fuel generation. An example of pioneering Ag-SBA-15 catalysts with unique visible-light sensitivity for hydrogen generation can be envisaged. ${ }^{160,164}$ More facile preparative approaches need to be developed for M-SBA-15 hybrid catalysts that are not only costeffective but also environmentally benign, with retention of superior catalytic performance and stability.

We expect that the research works summarized here will stimulate further interest in this fast-moving field and assist in the development of functionalized SBA-15 as the support material. For better results, it is important to study new and different methods of synthesis for modifying SBA-15 with different functional groups to obtain improved structural, textural and physicochemical properties, with a view to addressing the catalytic descriptors that we have outlined in this review. The descriptors that we have summarized in this review could be instrumental in scoping future research direction of using mesoporous SBA-15 as a novel support material for industrial applications. Future research could be tailored, not only explore new applications, but also find new strategies to 
stabilize heteroatoms on silica for preparing novel catalysts to address emerging catalytic applications.

\section{Conflicts of interest}

There are no conflicts to declare.

\section{Acknowledgements}

The present work was partially supported by Grants-in-Aid for Scientific Research (Nos. 19K15311, 26220911, 18K14056, $19 \mathrm{H} 00838$ ) from the Japan Society for the Promotion of Science (JSPS) and MEXT. YK, KM and HY thank MEXT program "Element Strategy Initiative" (No. JPMXP0112101003). This work was supported by the International Joint Research Promotion Program of Osaka University. PV would like to acknowledge the Royal Society-Newton International Fellowship (NIF \R1\180185) for her postdoctoral research funding at the University of Southampton, UK.

\section{Notes and references}

1 Z. Wu and D. Zhao, Chem. Commun., 2011, 47, 3332-3338.

2 F. Schüth and W. Schmidt, Adv. Eng. Mater., 2002, 4, 269-279.

3 Y. Wei, D. Jin, T. Ding, W-H. Shih, X. Liu, S.Z.D. Cheng and Q. Fu, Adv. Mater., 1998, 3, 313-316.

4 J.M. Kim and G.D. Stucky, Chem. Commun., 2000, 1159-1160.

5 S-H. Wu, C-Y. Mou and H-P. Lin, Chem. Soc. Rev., 2013, 42, 3862-3875.

6 M.D. Jones, R. Raja, J.M. Thomas, B.F.G. Johnson, D.W. Lewis, J. Rouzaud and K.D.M. Harris, Angew. Chem. Int. Ed., 2003, 42, 4326-4331.

7 C. Perego and R. Millini, Chem. Soc. Rev., 2013, 42, 3956-3976.

8 R. Raja, J.M. Thomas, M.D. Jones, B.F.G. Johnson and D.E.W. Vaughan, J. Am. Chem. Soc., 2003, 125, 14982-14983.

9 A. Corma, V. Fornés, M-Triguero and S.B. Pergher, J. Catal. 1999, 186, 57-63.

10 S.H. Newland, D.J. Xuereb, E. Gianotti, L. Marchese, R. Rios and R. Raja, Catal. Sci. Technol., 2015, 5, 660-665.

11 A.L. Doadrio, E.M.B. Sousa, J.C. Doadrio, J.P. Pariente, I.IBarba, M.V-Regí, J. Control. Release, 2004, 97, 125-132.

12 J. C. Doadrio, E.M.B. Sousa, I.I-Barba, A.L. Doadrio, J.PPariente and M.V-Regí, J. Mater. Chem., 2006, 16, 462-466.

13 S. Wang, Microporous Mesoporous Mater., 2009, 117, 1-9.

14 A. Szegedi, M. Popova, I. Goshev and J. Mihály, J. Solid State Chem., 2011, 184, 1201-1207.

15 T-L. Chew, A.L. Ahmad and S. Bhatia, Adv. Colloid Interface Sci., 2010, 153, 43-57.

16 Z. Li, J.C. Barnes, A. Bosoy, J. F. Stoddart and J.I. Zink, Chem. Soc. Rev., 2012, 41, 2590- 2605.

17 Y. Bai, H. Yang, W. Yang, Y. Li and C. Sun, Sens. Actuators $B$ Chem., 2007, 124, 179-186.

18 M. Hasanzadeh, N. Shadjou, M. de la Guardia, M. Eskandani and P. Sheikhzadeh, Trends Anal. Chem., 2012, 33, 117129.

19 C-H. Huang, K-P. Chang, H-D. Ou, Y-C. Chiang and C-F. Wang, Microporous Mesoporous Mater., 2011, 141, 102-109.

20 Q. Hu, J.J. Li, Z.P. Hao, L.D. Li and S. Z. Qiao, Chem. Eng. J., 2009, 149, 281-288

21 M. Hartmann and A. Vinu, Langmuir, 2002, 18, 8010-8016.

22 R. Raja, T. Khimyak, J.M. Thomas, S. Hermans and B.F.G. Johnson, Angew. Chem. Int. Ed., 2001, 40, 4638-4642.
23 J.M. Thomas and R. Raja, J. Organomet. Chem., 2004, 689, 4110-4124.

24 S-H. Wu, Y. Hung and C-Y. Mou, Chem. Commun., 2011, 47, 9972-9985.

25 X.S. Zhao, X. Y. Bao, W. Guo and F.Y. Lee, Mater. Today, 2006 , 9, 32-39.

26 J.M. Thomas and R. Raja, Acc. Chem. Res., 2008, 41, 708-720.

27 J.M. Thomas, B.F.G. Johnson, R. Raja, G. Sankar and P.A. Midgley, Acc. Chem. Res., 2003, 36, 20-30.

28 Y-J. Han, J.M. Kim and G.D. Stucky, Chem. Mater., 2000, 12 2068-2069.

29 R.M. Rioux, H. Song, J.D. Hoefelmeyer, P. Yang and G.A. Somorjai, J. Phys. Chem. B, 2005, 109, 2192-2202.

30 J. Sun and X. Bao, Chem. Eur. J., 2008, 14, 7478-7488.

31 J.S. Beck, J.C. Vartuli, W.J. Roth, M.E. Leonowicz, C.T. Kresge, K.D. Schmitt, C.T.-W. Chu, D.H. Olson, E.W. Sheppard, S.B. McCullen, J.B. Higgins and J.L. Schlenker, J. Am. Chem. Soc., 1992, 114, 10834-10843.

32 P. Yang, D. Zhao, B.F. Chmelka, G.D. Stucky, Chem. Mater., 1998, 10, 2033-2036.

33 H. Wang and C-J. Liu, Appl. Catal. B, 2011, 106, 672-680.

34 X-K. Li, W-J. Ji, J. Zhao, S-J. Wang and C-T. Au, J. Catal., 2005, 236, 181-189.

35 P. Liu, C-Y. Zhou, S. Xiang and C-M. Che, Chem. Commun., 2010, 46, 2739-2741.

36 Y-F. Han, F. Chen, Z. Zhong, K. Ramesh, L. Chen and E. Widjaja, J. Phys. Chem. B, 2006, 110, 24450-24456.

37 Z. Ma and S. Dai, Nano Res., 2011, 4, 3-32.

$38 \mathrm{~V}$-T. Hoang, Q. Hunag, M. Eić, T-O. Do and S. Kaliaguine, Langmuir, 2005, 21, 2051-2057.

39 C-M. Wu, M. Rathi, S.P. Ahrenkiel, R.T. Koodali and Z. Wang Chem. Commun., 2013, 49, 1223-1225.

40 X. Xu, H. Xu, F. Kapteijn and J.A. Moulijn, Appl. Catal. B, 2004 53, 265-274.

41 J. Dhainaut, J-P. Dacquin, A.F. Lee and K. Wilson, Green Chem., 2010, 12, 296-303

42 B. Naik, S. Hazra, V.S. Prasad and N.N. Ghosh, Catal. Commun., 2011, 12, 1104-1108.

43 Y. Jiang and Q. Gao, J. Am. Chem. Soc., 2006, 128, 716-717.

44 P. Shah, A.V. Ramaswamy, K. lazar and V. Ramaswamy, Appl. Catal. A, 2004, 273, 239-248.

45 T. Kamegawa, D. Yamahana and H. Yamashita, J. Phys. Chem. C, 2010, 114, 15049-15053.

46 Y. Li, Z. Feng, R.A. van Santen, E.J.M. Hensen and C. Li, J. Catal. 2008, 255, 190-196.

47 S. Lin, L. Shi, M.M.L. R. Carrott, P.J.M. Carrott, J. Rocha, M.R. Li and X.D. Zhou, Microporous Mesoporous Mater., 2011, 142, 526-534.

48 S-Y. Chen, L-Y. Jang and S. Cheng, Chem. Mater., 2004, 16, 4174-4180.

49 V.L. Zholobenko, A.Y. Khodakov, M.I-Clerc, D. Durand and I. Grillo, Adv. Colloid Interface Sci., 2008, 142, 67-74.

50 F-S. Xiao, Catal. Surv. Asia, 2004, 8, 151-159.

51 B. Albela and L. Bonneviot, New J. Chem., 2016, 40, 4115 4131

52 N. Rahmat, A.Z. Abdullah and A.R. Mohamed, Am. J. Appl. Sci. $2010,7,1579-1586$.

53 V. Chaudhary and S. Sharma, J. Porous Mater., 2017, 24, 741749.

54 G.M. Ziarani, S. Rohani, A. Ziarati and A. Badiei, RSC Adv. 2018, 8, 41048-41100

55 M. Nasrollahzadeh, M. Atarod, M. Alizadeh, A. Hatamifard and S.M. Sajadi, Curr. Org. Chem., 2017, 21, 708-749.

56 T. Joseph, S.S. Deshpande, S.B. Halligudi, A. Vinu, S. Ernst and M. Hartmann, J. Mol. Catal. A-Chem., 2003, 206, 13-21.

57 S.L. Suib, J. Přech, J. Čejka, Y. Kuwahara, K. Mori and H. Yamashita, Mater. Today, 2020, 32, 244-259. 
58 I. Toreci, F.H. Tezel, Y. Yong and A. Sayari, Adsorpt. Sci. Technol., 2006, 24, 79-99.

59 V.F. Vavsari, G.M. Ziarani and A. Badiei, RSC Adv., 2015, 5, 91686-91707.

60 L-F. Gutiérrez, S. Hamoudi and K. Belkacemi, Catalysts, 2011, 1, 97-154.

61 J. Zhu, T. Wang, X. Xu, P. Xiao and J. Li, Appl. Catal. B, 2013, 130, 197-217.

62 G.J. de A.A. S-Illia, E.L. Crepaldi, D. Grosso and C. Sanchez, Curr. Opin. Colloid Interface Sci., 2003, 8, 109-126.

63 D.P. Serrano, J. Aguado and J.M. Escola, ACS Catal., 2012, 2, 1924-1941.

64 E.N. Kusumawati and T. Sasaki, Chem. Rec., 2019, 1, 1-12.

65 M. Crucianelli, B.M. Bizzarri and R. Saladino, Catalysts, 2019, 9, 984-1014.

66 M. Kosmulski, E. Mczka and L. Ruchomski, Colloids Interfaces, 2018, 2, 59-87.

67 H. Wu, G. Pantaleo, A.M. Venezia and L.F. Liotta, Catalysts, 2013, 3, 774-793.

68 G.M. Ziarani, Z. Hassanzadeh, P. Gholamzadeh, S. Asadi and A. Badiei, RSC Adv., 2016, 6, 21979-22006.

69 H. Balcar and J. Čejka, Catalysts, 2019, 9, 743-761.

70 R. Schlögl, Angew. Chem. Int. Ed., 2015, 54, 3465-3520.

71 K.K. Sharma and T. Asefa, Angew. Chem. Int. Ed., 2007, 119, 2937-2940.

72 L.J. Broadbelt and R.Q. Snurr, Appl. Catal. A, 2000, 200, 23-46.

73 M. Boutonnet, S. Lögdberg and E.E. Svensson, Curr. Opin. Colloid Interface Sci., 2008, 13, 270-286.

74 J.R.H. Ross, Heterogeneous Catalysis Fundamentals and Applications Elsevier, Amsterdam, 2012, 232p, ISBN 9780444533630.

75 J. Liang, Z. Liang, R. Zou and Y. Zhao, Adv. Mater., 2017, 29, 1701139-1701160.

76 J.A. Melero, G.D. Stucky, R. van Grieken and G. Morales, J. Mater. Chem., 2002, 12, 1664-1670.

77 R.K. Zeidan, S-J. Hwang and M.E. Davis, Angew. Chem. Int. Ed., 2006, 45, 6332-6335.

78 B. Karimi, S. Abedi, J.H. Clark and V. Budarin, Angew. Chem. Int. Ed., 2006, 118, 4894-4897.

79 G. Dosseh, Y. Xia and C. A-Simionesco, J. Phys. Chem. B, 2003, 107, 6445-6453.

80 B. Grunberg, T. Emmler, E. Gedat, I. Shenderovich, G.H. Findenegg, H-H. Limbach and G. Buntkowsky, Chem. Eur. J., 2004, 10, 5689-5696.

81 PR. Selvakannan, K. Mantri, J. Tardio and S.K. Bhargava, J. Colloid Interface Sci., 2013, 394, 475-484.

82 H. Yamashita, K. Mori, Y. Kuwahara, T. Kamegawa, M. Wen, P. Verma and M. Che, Chem. Soc. Rev., 2018, 47, 8072-8096.

83 K. Mori, P. Verma, R. Hayashi, K. Fuku and H. Yamashita, Chem. Eur. J., 2015, 21, 11885-11893.

84 H. Yamashita and K. Mori, Chem. Lett., 2007, 36, 348-353.

85 H. Yamashita, K. Mori, S. Shironita and Y. Horiuchi, Catal. Surv. Asia, 2008, 12, 88-100.

86 P.S-Winkel, P. Yang, D.I. Margolese, B.F. Chmelka, G.D. Stucky, Adv. Mater.,1999,11, 303-307.

87 D. Zhao, P. Yang, B.F. Chmelka, G.D. Stucky, Chem. Mater., 1999, 11, 1174-1178.

88 P. Yang, T. Deng, D. Zhao, P. Feng, D. Pine, B.F. Chmelka, G.M Whitesides, G.D. Stucky, Science, 1998, 282, 2244-2246.

89 M. Kruk and M. Jaroniec, Chem. Mater., 2000, 12, 1961-1968.

90 D. Zhao, J. Sun, Q. Li and G.D. Stucky, Chem. Mater., 2000, 12, 275-279.

91 D. Zhao, J. Feng, Q. Huo, N. Melosh, G.H. Fredrickson, B.F. Chmelka, G.D. Stucky, Science, 1998, 279, 548-552.

92 D. Zhao, Q. Huo, J. Feng, B.F. Chmelka, G.D. Stucky, J. Am. Chem. Soc., 1998, 120, 6024-6036.

93 D. Zhao, P. Yang, N. Melosh, J. Feng, B.F. Chmelka, G.D. Stucky, Adv. Mater., 1998, 10, 1380-1385.
94 a) P.S-Winkel, W.W. Lukens, D. Zhao, P. Yang, B.F. Chmelka and G.D. Stucky, J. Am. Chem. Soc., 1999, 121, 254-255, b) SJ. Reich, A. Svidrytski, A. Höltzel, J. Florek, F. Kleitz, W. Wang, C. Kübel, D. Hlushkou and U. Tallarek, J. Phys. Chem. C, 2018, 122, 12350-12361.

95 a) M. Kruk and L. Cao, Langmuir, 2007, 23, 7247-7254, b) A. Katiyar, S. Yadav, P.G. Smirniotis and N.G. Pinto, J. Chromatogr. A, 2006, 1122, 13-20.

96 Y. Yin, Z-F Yang, Z-H. Wen, A-H. Yuan, X-Q. Liu, Z-Z. Zhang and H. Zhou, Sci. Rep., 2017, 7, 4509-4519.

97 S. Molaei, T. Tamoradi, M. Ghadermazi and A.GChoghamarani, Appl. Organomet. Chem., 2019, 33, e4649.

98 J. Lee, K. Kim, I.S. Chang, M-G Kim, K-S. Ha, E.Y. Lee, J. Lee and C. Kim, J. Mol. Liq., 2016, 215, 154-160.

99 L. Wang, L. Zhang, H. Li, Y. Ma and R. Zhang, Compos. B Eng., 2019, 156, 88-94.

100 A.R-Gómez, F. Platero, A. Caballero and G. Colón, Mol. Catal., 2018, 445, 142-151.

101 D. Pečar and A. Goršek, React. Kinet. Mech. Cat., 2019, 128, 991-1003.

102 Z. Bahrami, A. Badiei and G.M. Ziarani, J. Nanopart. Res., 2015, 12, 125-137.

103 A.B-Sedjerari, J.D.A. Pelletier, E.A-Hamad, L. Emsley and JM. Basset, Chem. Commun., 2012, 48, 3067-3069.

104 G. Zhang, P. Zhao, Y. Xu, Z. Yang, H. Cheng and Y. Zhang, ACS Appl. Mater. Interfaces, 2018, 10, 34340-34354.

105 R. de la S. Valdés, J. Agúndez, C.M-Álvarez and J.P Pariente, Catal. Today, https://doi.org/10.1016/j.cattod.2019.09.014.

106 J.P.V. Damasceno, C. M. Maroneze, M. Strauss, F.A. Sigoli and I. O. Mazali, New. J. Chem., 2016, 40, 6636-6642.

107 V. Morales, M.N. Idso, M. Balabasquer, B. Chmelka and R.A.G-Muñoz, J. Phys. Chem. C, 2016, 120, 16887-16898.

108 A.V. Bordoni, M.V. Lombardo, A.E. Regazzoni, G.J.A.A.SIllia and A. Wolosiuk, J. Colloid Interface Sci., 2015, 450, 316324.

109 J.D. Webb, T. Seki, J.F. Goldston, M. Pruski and C.M. Crudden, Microporous Mesoporous Mater., 2015, 203, 123 131.

110 Y.S-Vicente, L.A. Stevens, C. Pando, M.J. Torralvo, C.E. Snape, T.C. Drage and A. Cabañas, Chem. Eng. J., 2015, 264, 886-898.

111 M.J. Tenorio, J. Morère, C. Carnerero, M.J. Torralvo, C. Pando and A. Cabañas, Microporous Mesoporous Mater., 2018, 256, 147-154.

112 M. Jin, Z. Guo, X. Ge and Z. Lv, Reac. Kinet. Mech. Cat., 2018, 125, 1139-1157.

113 P. Bhanja, A. Modak, S. Chatterjee and A. Bhaumik, ACS Sustainable Chem. Eng., 2017, 5, 2763-2773.

114 H. Yamashita, Y. Ichihashi, M. Anpo, M. Hashimoto, C. Louis and M. Che, J. Phys. Chem., 1996, 100, 16041-16044.

115 H. Yamashita, K. Yoshizawa, M. Ariyuki, S. Higashimoto, M. Che and M. Anpo, Chem. Commun., 2001, 435-436.

116 K. Mori, T. Araki, S. Shironita, J. Sonoda and H. Yamashita, Catal. Lett., 2009, 131, 337-343.

117 K. Mori, K. Sugihara, Y. Kondo, T. Takeuchi, S. Morimoto and H. Yamashita, J. Phys. Chem. C, 2008, 112, 16478-16483.

118 K. Mori, Y. Kondo, S. Morimoto and H. Yamashita, J. Phys. Chem. C, 2008, 112, 397-404.

119 Y. Sohn, W. Huang and F. Taghipour, Appl. Surf. Sci., 2017, 396, 1696-1711.

120 S. Higashimoto, Y. Hu, R. Tsumura, K. lino, M. Matsuoka, H. Yamashita, Y. G. Shul, M. Che and M. Anpo, J. Catal., 2005, 235, 272-278.

121 K. Mori and H. Yamashita, Phys. Chem. Chem. Phys., 2010, 12, 14420-14432. 
122 S. Higashimoto, M. Matsuoka, H. Yamashita, M. Anpo, O. Kitao, H. Hidaka, M. Che and E. Giamello, J. Phys. Chem. B 2000, 104, 10288-10292.

123 J. M. Thomas and G. Sankar, Acc. Chem. Res., 2001, 34, $571-581$

124 N. U. Zhanpeisov, M. Matsuoka, H. Yamashita and M. Anpo, J. Phys. Chem. B, 1998, 102, 6915-6920.

125 H. Yamashita, S. Kawasaki, Y. Ichihashi, M. Harada, M. Takeuchi, M. Anpo, G. Stewart, M. A. Fox, C. Louis and M. Che, J. Phys. Chem. B, 1998, 102, 5870-5875.

126 Y. Horiuchi, K. Mori, N. Nishiyama and H. Yamashita, Chem. Lett., 2008, 37, 748-749.

127 K. Mori, Y. Miura, S. Shironita and H. Yamashita, Langmuir, 2009, 25, 11180-11187.

128 S. Okada, S. Ikurumi, T. Kamegawa, K. Mori and H. Yamashita, J. Phys. Chem. C, 2012, 116, 14360-14367.

129 C. Nozaki, C.G. Lugmair, A.T. Bell and T. D. Tilley, J. Am. Chem. Soc., 2002, 124, 13194-13203.

130 J. Jarupatrakorn, T.D. Tilley, J. Am. Chem. Soc., 2002, 124 8380-8388.

131 H. Cui, Y. Zhang, Z. Qiu, L. Zhao and Y. Zhu, Appl. Catal. B, 2010, 101, 45-53.

132 Z. Lou, R. Wang, H. Sun, Y. Chen and Y. Yang, Microporous Mesoporous Mater., 2008, 110, 347-354.

133 P. Verma, Y. Kuwahara, K. Mori and H. Yamashita, Chem. Eur. J., 2017, 23, 3616-3622.

134 W. Xu, B. Yu, Y. Zhang, X. Chen, G. Zhang and Z. Gao, Appl. Surf. Sci., 2015, 325, 227-234.

135 W. Xu, Y. Li, B. Yu, J. Yang, Y. Zhang, X. Chen, G. Zhang and Z. Gao, J. Solid State Chem., 2015, 221, 208-215.

$136 \mathrm{~T}$. Fu, Y. Wang, A. Wernbacher, R. Schlögl and A. Trunschke, ACS Catal., 2019, 9, 4875-4886.

137 L.M. Azofra, N. Morlanés, A. Poater, M.K. Samantaray, B. Vidjayacoumar, K. Albahily, L. Cavallo and J-M. Basset, Angew. Chem. Int. Ed., 2018, 57, 15812-15816.

138 Y. Yin, H. Wu, L. Shi, J. Zhang, X. Xu, H. Zhang, S. Wang, M. Sillanpääd and H. Sun, Environ. Sci. Nano, 2018, 5, 2842-2852.

139 M.W. McKittrick and C.W. Jones, J. Am. Chem. Soc., 2004, 126, 3052-3053.

140 J.S. Lee, J-H. Yim, J-K. Jeon, Y. S. Ko, Catal. Today, 2012, $185,175-182$.

141 T. Kamegawa, N. Suzuki, K. Tsuji, J. Sonoda, Y. Kuwahara, K. Mori and H. Yamashita, Catal. Today, 2011, 175, 393-397.

142 Y. Kuwahara, D-Y. Kang, J.R. Copeland, N.A. Brunelli, S.A. Didas, P. Bollini, C. Sievers, T. Kamegawa, H. Yamashita and C. W. Jones, J. Am. Chem. Soc., 2012, 134, 10757-10760.

143 Y. Kuwahara, D-Y. Kang, J.R. Copeland, P. Bollini, C. Sievers, T. Kamegawa, H. Yamashita and C. W. Jones, Chem. Eur. J., 2012, 18, 16649-16664

144 Y. Kuwahara, T. Fujitani and H. Yamashita, Catal. Today 2014, 237, 18-28.

145 A. Mavrogiorgou, M. Baikousi, V. Costas, E. Mouzourakis, Y. Deligiannakis, M.A. Karakassides and M. Louloudi, J. Mol. Catal. Chem., 2016, 413, 40-55.

146 S. Garg, K. Soni, T.A. Prabhu, K.S. Rama Rao and G.M. Dhar Catal. Today, 2016, 216, 128- 136

147 X. Dong, J. Lu, Y. Yu and M. Zhang, Phys. Chem. Chem. Phys., 2018, 20, 12970-12978.

148 M. Ogura, R.G-Nicolas, D. Brouri, S. Casale, J. Blanchard, K.A. Cychosz, M. Thommes and C. Thomas, Microporous Mesoporous Mater., 2016, 225, 440-449.

149 J. Zhang, M. Zhang, X. Wang, Q. Zhang, F. Song, Y. Tan and Y. Han, New. J. Chem., 2017, 41, 9639-9648.

150 Y-Y. Meng, Q-D. An, Z-Y. Xiao, S-R. Zhai and Z. Shi, Microporous Mesoporous Mater., 2018, 266, 64-74.

151 A.I. Acatrinei, M.A. Hartl, J. Eckert, E. H. L. Falcao, G. Chertkov and L.L. Daemen, J. Phys. Chem. C, 2009, 113, 1563415638.
152 P. Verma, Y. Kuwahara, K. Mori and H. Yamashita, J. Mater. Chem. A, 2015, 3, 18889-18897.

153 K. Fuku, R. Hayashi, S. Takakura, T. Kamegawa, K. Mori and H. Yamashita, Angew. Chem. Int. Ed., 2013, 52, 7446-7450.

154 P. Verma, M. Navlani-García, Y. Kuwahara, K. Mori and H. Yamashita, J. Chem. Sci., 2017, 129, 1661-1669.

155 S. Sadjadi, M.M. Heravi and M. Ebrahimizadeh, J. Porous Mater., 2018, 25, 779-788.

156 B. Erdogan, H. Arbag and N. Yasyerli, Int. J. Hydrog. Energy 2018, 43, 1396-1405.

157 A. Saad, Y. Snoussi, M. Abderrabba and M.M. Chehimi, RSC Adv., 2016, 6, 57672-57682.

158 A. Saad, C. Vard, M. Abderrabba and M.M. Chehimi, Langmuir, 2017, 33, 7137-7146.

159 a) N.H. Le, S.H-Garreau, M. Bonne, C.M-Sayago, B. Louis, B. Lebeau and L. Balan, Microporous Mesoporous Mater., 2020, 295, 109952-109964; b) P. Verma, K. Mori, Y. Kuwahara, S. J. Cho and H. Yamashita, Catal. Today, 2019, https://doi.org/10.1016/j.cattod.2019.10.014.

160 P. Verma, Y. Kuwahara, K. Mori and H. Yamashita, Bull. Chem. Soc. Jpn., 2019, 92, 19-29.

161 P. Verma, Y. Kuwahara, K. Mori and H. Yamashita, J. Mater. Chem., A 2016, 4, 10142-10150.

162 P. Verma, Y. Kuwahara, K. Mori and H. Yamashita, Catal. Sci. Technol., 2017, 7, 2551-2558.

163 P. Verma, K. Yuan, Y. Kuwahara, K. Mori and H. Yamashita, Appl. Catal. B, 2018, 223, 10-15.

164 P. Verma, Y. Kuwahara, K. Mori and H. Yamashita, Current Developments in Photocatalysis and Photocatalytic Materials, ed. X. Wang, M. Anpo and X. Fu, Elsevier, Amsterdam, 2020, ch. 22 , pp. 353-368.

165 X. Zhang, H. Dong, Y. Wang, N. Liu, Y. Zuo and L. Cui, Chem. Eng. J., 2016, 283, 1097-1107.

166 S.H. Gage, J. Engelhardt, M.J. Menart, C. Ngo, G. J. Leong, Y. Ji, B.G. Trewyn, S. Pylypenko and R.M. Richards, ACS Omega, 2018, 3, 7681-7691.

167 Z. Zhang, J. Cheng, Y. Luo, W. Shi, W. Wang, B. Zhang, R. Zhang, X. Bao, Y. Guo and F. Cui, Catal Commun., 2018, 105, 11-15.

168 S.J. Canhaci, R.F. Perez, L.E.P. Borges and M.A. Fraga, Appl. Catal. B Environ., 2017, 207, 279-285.

169 X. Qian, Y. Kuwahara, K. Mori and H. Yamashita, Chem Eur J., 2014, 20, 15746-15752.

170 P. Verma, Y. Kuwahara, K. Mori and H. Yamashita, Catal. Today, 2019, 324, 83-89.

171 S. Jeong, K-H. Chung, H. Lee, H. Park, K-J. Jeon, Y-K. Park and S-C. Jung, ACS Sustainable Chem. Eng., 2017, 5, 36593666.

172 X. Cheng, D. Wang, J. Liu, X. Kang, H. Yan, A. Wu, Y. Gu, C. Tian and H. Fu, Nanoscale, 2018, 10, 22348-22356.

173 F. Chang, M. Jiao, Q. Xu, B. Deng and X. Hu, Appl. Surf. Sci., 2018, 435, 708-717.

174 X. Wei, X-F. Yang, A-Q Wang, L. Li, X-Y. Liu, T. Zhang, C-Y. Mou and J. Li, J. Phys. Chem. C, 2012, 116, 6222-6232.

175 A.R. Gomez, R. Pereñiguez and A. Caballero, Catal. Today, 2018, 307, 224-230.

176 N. Masoud, L. Delannoy, C. Calers, J-J. Gallet, F. Bournel, K.P. de Jong, C. Louis and P.E. de Jongh, ChemCatChem, 2017, 9, 2418-2425

177 Z. Wen, X. Duan, M. Hu, Y. Cao, L. Ye, L. Jiang and Y. Yuan, J. Environ. Sci., 2018, 64, 122-129.

178 R. Malhotra and A. Ali, Renew. Energy, 2019, 133, 606619.

179 M.A. Gondal, M.A. Suliman, M.A. Dastageer, G-K. Chuah, C. Basheer, D. Yang and A. Suwaiyan, J. Mol. Catal. A-Chem. 2016, 425, 208-216. 
180 A.F.S. Filho, J.F.C. Filho, M.S. Lima, L.M. Carvalho, L.K.R Silva, J.S. Costa, T.C.M. Dantas and G.E. Luz Jr, Water Air Soil Pollut., 2018, 229, 268-284.

181 Y. Kuwahara, W. Kaburagi and T. Fujitani, Bull. Chem. Soc. Jpn., 2014, 87, 1252-1254.

182 Y. Kuwahara, W. Kaburagi, Y. Osada, T. Fujitani and H. Yamashita, Catal. Today, 2017, 281, 418-428.

183 X. Qian, T. Kamegawa, K. Mori, H. Li and H. Yamashita, J. Phys. Chem. C, 2013, 117, 19544-19551.

184 M. Diekmann, G. Koch, M. König and T. Ressler, ChemCatChem, 2018, 10, 5459-5467.

185 H.V. Le, S. Parishan, A. Sagaltchik, H. Ahi, A. Trunschke, R. Schomäcker and A. Thomas, Chem. Eur. J., 2018, 24, 12592 12599.

186 J. Gonzalez, J.A. Wang, L.F. Chen, M.E. Manriquez and J.M. Dominguez, J. Phys. Chem. C, 2017, 121, 23988-23999.

187 G. Kučerová, J. Strunk, M. Muhler and R.J. Behm, J. Catal., 2017, 356, 214-228.

188 A. Silva, K. Wilson, A.F. Lee, V.C. dos Santos, A.C.C. Bacilla, K.M. Mantovani and S. Nakagaki, Appl. Catal. B, 2017, 205, 498-504.

189 J.J. Creasey, C.M.A. Parlett, J.C. Manayil, M.A. Isaacs, K. Wilson and A.F. Lee, Green Chem., 2015, 17, 2398-2405.

190 V. Calvino-Casilda, M. Olejniczak, R.M. Martín-Aranda and M. Ziolek, Microporous Mesoporous Mater., 2016, 224, 201-207.

191 M. Olejniczak and M. Ziolek, Microporous Mesoporous Mater., 2014, 196, 243-253.

192 Y. Tang, H. Gao, M. Yang, G. Wang, J. Li, H. Zhang and Z. Tao, New J. Chem., 2016, 40, 8543-8548.

193 D. Großmann, K. Klementiev, I. Sinev and W. Grünert ChemCatChem, 2017, 9, 365-372.

194 Q. Zhang, Y. Li, D. An and Y. Wang, Appl. Catal. A, 2009, 356, 103-111.

195 W. Yang, X. Wang, Q. Guo, Q. Zhang and Y. Wang, New J. Chem., 2003, 27, 1301-1303.

196 B. Lin, X. Wang, Q. Guo, W. Yang, Q. Zhang and Y. Wang, Chem. Lett., 2003, 32, 860-861.

197 V. Fornés, C. López, H.H. López and A. Martínez, Appl. Catal. A, 2003, 249, 345-354.

198 X. Wang, Y. Wang, Q. Tang, Q. Guo, Q. Zhang and H. Wan, J. Catal., 2003, 217, 457-467.

199 Y. Lou, Q. Tang, H. Wang, B. Chia, Y. Wang and Y. Yang, Appl. Catal. A, 2008, 350, 118-125.

200 Y. Li, S. Chen, Q. Zhang and Y. Wang, Chem. Lett., 2006, 35, 572-573.

201 Y. Wang, J. Ren, Z. Liu, Y. Wang, Y. Guo, Y. Guo and G. Lu, J. Colloid Interf. Sci., 2008, 326, 158-165.

202 Y. Snoussi, S. Bastide, M. Abderraba and M.M. Chehimi, Ultrason. Sonochem., 2018, 41, 551-561.

203 I. Ursachi, A. Stancu and A. Vasile, J. Colloid Interf. Sci., 2012, 377, 184-190.

204 H. Atashin and R. Malakooti, J. Saudi Chem. Soc., 2017, 21, S17-S24.

205 S. Erdem, B. Erdem and B.M. Öksüzoğlu, Anadolu Univ. J. Sci. Technology Appl. Sci. Eng., 2018, 19, 514-522.

206 M-H. Jin, D. Oh, J-H. Park, C-B. Lee, S-W. Lee, J-S. Park, KY. Lee and D-W. Lee, Sci. Rep., 2016, 6, 33502-33514.

207 Y. Qin, Z. Qu, C. Dong, Y. Wang and N. Huang, J. Environ. Sci., 2019, 76, 208-216.

208 J. Kou and L-B. Sun, ACS Appl. Mater. Interfaces, 2018, 10 12051-12059.

209 D. Gao, X. Zhang, X. Dai, Y. Qin, A. Duan, Y. Yu, H. Zhuo, H. Zhao, P. Zhang, Y. Jiang and Z. Zhao, Nano Research, 2016, 9, 3099-3115.

210 Y. Yang, J.W. Chang, R.M. Rioux, J. Catal., 2018, 365, 4354.
211 A.J. Sandee, J.N.H. Reek, P.C.J. Kamer and P.W.N.M. van Leeuwen, J. Am. Chem. Soc., 2001, 123, 8468-8476.

212 C. Merckle and J. Blumel, Adv. Synth. Catal., 2003, 345, 584-588.

213 S.-G. Shyu, S.-W. Cheng and D.-L. Tzou, Chem. Commun., 1999, 2337-2338.

214 Q. Peng, Y. Yang and Y. Yuan, J. Mol. Catal. A Chem., 2004, 219, 175-181.

215 W. Zhou and D. He, Green Chem., 2009, 11, 1146-1154.

216 S.C. Bourque, F. Maltais, W.-J. Xiao, O. Tardif, H. Alper, P. Arya and L.E. Manzer, J. Am. Chem. Soc., 1999, 121, 30353038.

217 F. Marras, J. Wang, M.-O. Coppens and J.N.H. Reek, Chem Commun., 2010, 46, 6587-6589.

218 Y. Yang and R.M. Rioux, Green Chem., 2014, 16, 39163925.

219 M. Zheng, Y. Ding, X. Cao, T. Tian and J. Lin, Appl. Catal. B, 2018, 237, 1091-1100.

220 K. Mori, M. Tottori, K. Watanabe, M. Che and H. Yamashita, J. Phys. Chem. C, 2011, 115, 21358-21362.

221 K. Mori, K. Watanabe, Y. Terai, Y. Fujiwara and H. Yamashita, Chem. Eur. J., 2012, 18, 11371-11378.

222 K. Mori, K. Watanabe, M. Kawashima, M. Che and H. Yamashita, J. Phys. Chem. C, 2011, 115, 1044-1050.

223 G. Feng, J. Wang, M. Boronat, Y. Li, J-H. Su, J. Huang, Y. Ma and J. Yu, J. Am. Chem. Soc., 2018, 140, 4770-4773.

224 K. Nakatsuka, Y. Kuwahara, K. Mori and H. Yamashita, Chem. Lett., 2015, 44, 1691-1693. 


\section{Table of Contents}

In this review paper, various strategies to functionalize SBA-15 mesoporous silica has been reviewed with a view to evaluating their efficacy in different catalytic transformation reactions.

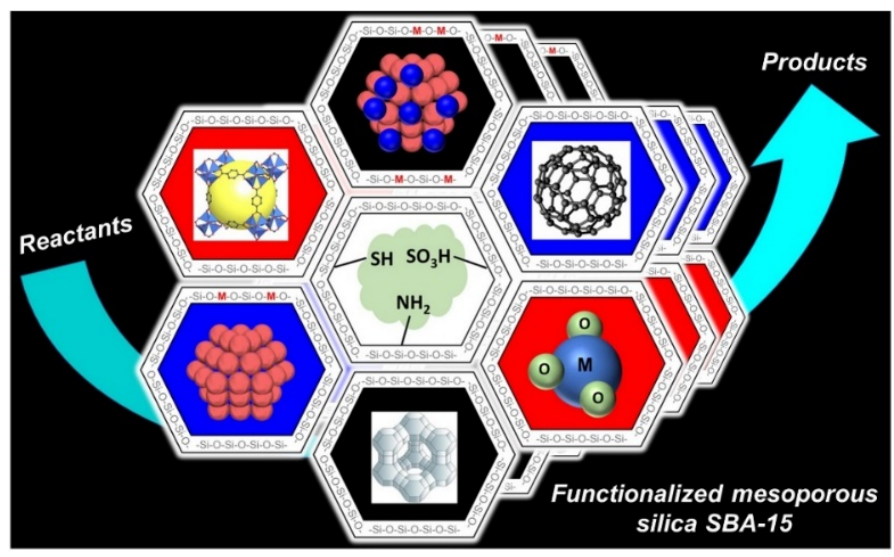



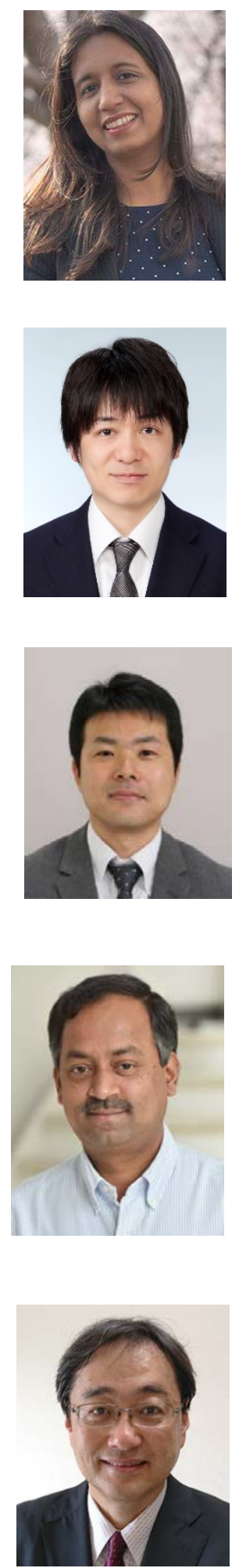

\section{Priyanka Verma}

Priyanka Verma did her Master of Science in Chemistry at Indian Institute of Technology, Hyderabad, India and received Institute Gold medal for academic excellence in 2014. She graduated her PhD degree in 2017 under the supervision of Prof. Hiromi Yamashita in the Graduate School of Engineering, Osaka University, Japan. She continued her research in the same group as a specially appointed assistant professor (2017-2019) at Osaka University. In 2019, she received the Royal Society-Newton International Fellowship to pursue her research in Prof. Robert Raja's group at the University of Southampton, UK. Her research interests are based on designing noble metal plasmonic nanomaterials for energy and environmental applications.

\section{Yasutaka Kuwahara}

Yasutaka Kuwahara received his PhD degree in engineering from Osaka University in 2011. He had been a postdoctoral research fellow at Georgia Institute of Technology, USA in 2011. He had been a researcher at National Institute of Advanced Industrial Science and Technology (AIST), Japan in 2012-2014. He had been appointed as an assistant professor in 2014-2019 and has been appointed as a lecturer since 2019 in Osaka University. His current research interests include the design of nanostructured catalysts with multifunctionalities utilizing porous materials and their applications to green chemical reactions and conversion of energy and resources.

\section{Kohsuke Mori}

Kohsuke Mori received his PhD degree from the Graduate School of Engineering Science at Osaka University under the supervision of Prof. K. Kaneda in 2003. In 2004, he joined Prof. T. Don, Tilley's group at University of California, Berkeley as a postdoctoral fellow. He moved to current faculty in 2005 and then became an associate professor in 2009. His current research interests focus on hybrid photocatalysts based on visible-light-responsible metal complexes, metal and alloy nanoparticle catalysts to establish clean and environmentally-friendly chemical processes, and diesel automobile catalysts.

\section{Robert Raja}

Robert Raja is a Professor of Materials Chemistry and Catalysis at the University of Southampton and the focal theme of research within his Group entails the discovery and design of novel catalytic materials, for application as heterogeneous catalysts in chemical, pharmaceutical, fine-chemical and environmental sectors, for developing sustainable technologies. His career includes appointments at the University of Cambridge (1999-2006), Bayer Chemicals, Germany (2001-2003) and 1851 Exhibition at the Royal Institution of Great Britain (1997-1999). Notable accolades include the Erskine Fellowship and the Barrer Award from the Royal Society of Chemistry 'for outstanding contributions to materials chemistry and industrial catalysis'.

\section{Hiromi Yamashita}

Hiromi Yamashita has been a professor of Osaka University since 2004. He received PhD degree from Kyoto University in 1987. He was an assistant professor of Tohoku University, an associate professor of Osaka Prefecture University. He was also visiting research fellows of California Institute of Technology. He is now the president of Catalysis Society of Japan (2019-2020) and the president of Asia-Pacific Association of Catalysis Societies (2019-2022). His research interests include the design of single-site photocatalysts and nanostructured catalysts. 